\title{
Risk models and scores for type 2 diabetes: systematic review
}

\author{
(C) $(1) \Theta$ OPEN ACCESS
}

\author{
Douglas Noble lecturer ${ }^{1}$, Rohini Mathur research fellow ${ }^{1}$, Tom Dent consultant ${ }^{2}$, Catherine Meads \\ senior lecturer ${ }^{1}$, Trisha Greenhalgh professor ${ }^{1}$
}

${ }^{1}$ Centre for Primary Care and Public Health, Barts and the London School of Medicine and Dentistry, London E1 2AT, UK; ${ }^{2} \mathrm{PHG}$ Foundation, Cambridge, UK

\begin{abstract}
Objective To evaluate current risk models and scores for type 2 diabetes and inform selection and implementation of these in practice.

Design Systematic review using standard (quantitative) and realist (mainly qualitative) methodology.

Inclusion criteria Papers in any language describing the development or external validation, or both, of models and scores to predict the risk of an adult developing type 2 diabetes.

Data sources Medline, PreMedline, Embase, and Cochrane databases were searched. Included studies were citation tracked in Google Scholar to identify follow-on studies of usability or impact.
\end{abstract}

Data extraction Data were extracted on statistical properties of models, details of internal or external validation, and use of risk scores beyond the studies that developed them. Quantitative data were tabulated to compare model components and statistical properties. Qualitative data were analysed thematically to identify mechanisms by which use of the risk model or score might improve patient outcomes.

Results 8864 titles were scanned, 115 full text papers considered, and 43 papers included in the final sample. These described the prospective development or validation, or both, of 145 risk prediction models and scores, 94 of which were studied in detail here. They had been tested on 6.88 million participants followed for up to 28 years. Heterogeneity of primary studies precluded meta-analysis. Some but not all risk models or scores had robust statistical properties (for example, good discrimination and calibration) and had been externally validated on a different population. Genetic markers added nothing to models over clinical and sociodemographic factors. Most authors described their score as "simple" or "easily implemented," although few were specific about the intended users and under what circumstances. Ten mechanisms were identified by which measuring diabetes risk might improve outcomes. Follow-on studies that applied a risk score as part of an intervention aimed at reducing actual risk in people were sparse.
Conclusion Much work has been done to develop diabetes risk models and scores, but most are rarely used because they require tests not routinely available or they were developed without a specific user or clear use in mind. Encouragingly, recent research has begun to tackle usability and the impact of diabetes risk scores. Two promising areas for further research are interventions that prompt lay people to check their own diabetes risk and use of risk scores on population datasets to identify high risk "hotspots" for targeted public health interventions.

\section{Introduction}

The prevalence of diabetes is rising rapidly throughout the world. ${ }^{1}$ By 2010 its prevalence in the adult populations of the United Kingdom, the United States, mainland China, and the United Arab Emirates had exceeded $7 \%,{ }^{2} 11 \%,{ }^{3} 15 \%,{ }^{4}$ and $17 \%,{ }^{5}$ respectively. Americans born in 2000 or later have a lifetime risk of more than one in three of developing diabetes. ${ }^{6}$ Type 2 diabetes (which accounts for over $95 \%$ of diabetes worldwide) results from a complex gene-environment interaction for which several risk factors, such as age, sex, ethnicity, family history, obesity, and hypertension, are well documented. The precise interaction of these and other risk factors with one another is, however, a complex process that varies both within and across populations. ${ }^{7-11}$ Epidemiologists and statisticians are striving to produce weighted models that can be presented as scores to reflect this complexity but which at the same time are perceived as sufficiently simple, plausible, affordable, and widely implementable in clinical practice. ${ }^{12}$

Cohort studies have shown that early detection of established diabetes improves outcome, although the evidence base for screening the entire population is weak. ${ }^{14}{ }^{15}$ The proportion of cases of incident type 2 diabetes in people with impaired glucose tolerance or impaired fasting glucose levels was reduced in landmark trials from China ${ }^{16}$ Finland,${ }^{17}$ and the United States ${ }^{18}$ by up to $33 \%, 50 \%$, and $58 \%$, respectively, through lifestyle 
changes (increased exercise, weight loss) or pharmacotherapy, or both, although changes may be more modest in a non-trial population. Some have argued that because combining known risk factors predicts incident diabetes at least as effectively as impaired glucose metabolism, a diabetes risk score may be a better and more practical means of identifying people for preventive interventions than either a glucose tolerance test or a fasting blood glucose level. ${ }^{19}$ Others favour targeting the assessment of diabetes risk in those with established impaired glucose metabolism on the basis that interventions in this group are particularly effective. ${ }^{20}$

Risk models and scores first emerged for cardiovascular disease, and these are widely used in clinical and public health practice. In the United Kingdom, for example, all electronic patient record systems in general practice offer the facility to calculate the Framingham score, a patient's risk of a cardiovascular event within 10 years. This risk score features in many guidelines and decision pathways (such as the cut-off for statin therapy ${ }^{21}$ ), and general practitioners receive financial rewards for calculating it. ${ }^{22}$ In contrast, although numerous models and scores have been developed for diabetes risk, we found limited evidence for use of these as part of a formal health policy, guideline, or incentive scheme for practitioners in any country (one Australian scheme incentivises general practitioners' measurement of the risk of diabetes in adults aged 40-49 ${ }^{23}$ ). This is perhaps surprising, given that morbidity and mortality from cardiovascular disease has been decreasing in many countries since the $1970 \mathrm{~s},{ }^{24}$ whereas those from diabetes continue to increase. $^{3}$

A diabetes risk score is an example of a prognostic model. ${ }^{25}$ Such scores should ideally be developed by taking a large, age defined population cohort of people without diabetes, measuring baseline risk factors, and following the cohort for a sufficiently long time to see who develops diabetes. ${ }^{26}$ Although prospective longitudinal designs in specially assembled cohorts are expensive, difficult, and time consuming to execute, cross sectional designs in which risk factors are measured in a population including people both with and without diabetes are methodologically inferior. They use prevalence as a proxy for incidence and conflate characteristics of people with diabetes with risk factors in those without diabetes, and thus are incapable of showing that a putative risk factor predated the development of diabetes. In practice, researchers tend to take one of two approaches: they either study a cohort of people without diabetes, which was assembled some years previously with relevant baseline metrics for some other purpose (for example, the British Regional Heart Study ${ }^{27}$ ), or they analyse routinely available data, such as electronic patient records. ${ }^{8}$ Both approaches are potentially susceptible to bias.

Some diabetes risk scores are intended to be self administered using questions such as "have you ever been told you have high blood pressure?" Scores that rely entirely on such questions may be hosted on the internet (see for example www.diabetes. org.uk/riskscore). Some researchers have used self completion postal questionnaires as the first part of a stepwise detection programme..$^{28}$ To the extent that these instruments are valid, they can identify two types of people: those who already have diabetes whether or not they know it (hence the questionnaire may serve as a self administered screening tool for undiagnosed diabetes) and those at high risk of developing diabetes- that is, it may also serve as a prediction tool for future diabetes. Prevalence rates for diabetes derived from self assessment studies thus cannot be compared directly with the rate of incident diabetes in a prospective longitudinal sample from which those testing positive for diabetes at baseline have been excluded.
A good risk score is usually defined as one that accurately estimates individuals' risk - that is, predictions based on the score closely match what is observed (calibration); the score distinguishes reliably between high risk people, who are likely to go on to develop the condition, and low risk people, who are less likely to develop the condition (discrimination); and it performs well in new populations (generalisability). Validating a risk model or score means testing its calibration and discrimination either internally (by splitting the original sample, developing the score on one part and testing it on another), temporally (re-running the score on the same or a similar sample after a time period), or, preferably, externally (running the score on a new population with similar but not identical characteristics from the one on which it was developed) ${ }^{26}{ }^{29}$ Caution is needed when extrapolating a risk model or score developed in one population or setting to a different one-for example, secondary to primary care, adults to children, or one ethnic group to another. $^{30}$

Risk scores and other prognostic models should be subject to "impact studies"- that is, studies of the extent to which the score is actually used and leads to improved outcomes. Although most authors emphasise quantitative evaluation of impact such as through cluster randomised controlled trials, ${ }^{30}$ much might also be learnt from qualitative studies of the process of using the score, either alone or as an adjunct to experimental trials. One such methodology is realist evaluation, which considers the interplay between context, mechanism (how the intervention is perceived and taken up by practitioners), and outcome. ${ }^{31}$ In practice, however, neither quantitative nor qualitative studies of impact are common in the assessment of risk scores. ${ }^{30}$

We sought to identify, classify, and evaluate risk models and scores for diabetes and inform their selection and implementation in practice. We wanted to determine the key statistical properties of published scores for predicting type 2 diabetes in adults and how they perform in practice. Hence we were particularly interested in highlighting those characteristics of a risk score that would make it fit for purpose in different situations and settings. To that end we reviewed the literature on development, validation, and use of such scores, using both quantitative data on demographics of populations and statistical properties of models and qualitative data on how risk scores were perceived and used by practitioners, policy makers, and others in a range of contexts and systems.

\section{Methods}

\section{Theoretical and methodological approach}

We followed standard methodology for systematic reviews, summarised in guidance from a previous study and the York Centre for Reviews and Dissemination. ${ }^{32} 33$ The process was later extended by drawing on the principles of realist review, an established form of systematic literature review that uses mainly qualitative methods to produce insights into the interaction between context, mechanism, and outcome, hence explaining instances of both success and failure. ${ }^{34}$ Our team is leading an international collaborative study, the Realist and Meta-narrative Evidence Synthesis: Evolving Standards (RAMESES) to develop methodological guidance and publication standards for realist review. ${ }^{35}$

\section{Search strategy}

We identified all peer reviewed cohort studies in adults over age 18 that had derived or validated, or both, a statistically weighted risk model for type 2 diabetes in a population not preselected for known risk factors or disease, and which could 
be applied to another population. Studies were included that had developed a new risk model based on risk factors and that used regression techniques to weight risk factors appropriately, or validated an existing model on a new population, or did both. Exclusion criteria were cross sectional designs, studies that had not finished recruiting, studies on populations preselected for risk factors or disease, studies that did not link multiple risk factors to form a scoring system or weighted model, screening or early detection studies, genetic studies, case series, studies on under 18s, animal studies, and studies that applied a known risk model or score to a population but did not evaluate its statistical potential.

In January 2011 we undertook a scoping search, beginning with sources known to the research team and those recommended by colleagues. We used the 29 papers from this search to develop the definitive protocol, including search terms and inclusion and exclusion criteria. In February 2011 a specialist librarian designed a search strategy (see web extra) with assistance from the research team. Key words were predict, screen, risk, score, [type two] diabetes, model, regression, risk assessment, risk factor, calculator, analysis, sensitivity and specificity, ROC and odds ratio. Both MESH terms and text words were used. Titles and abstracts were searched in Medline, PreMedline, Embase, and relevant databases in the Cochrane Library from inception to February 2011, with no language restrictions.

Search results from the different databases were combined in an endnote file and duplicates removed electronically and manually. In February and March 2011 two researchers independently scanned titles and abstracts and flagged potentially relevant papers for full text analysis.

Two researchers independently read the interim dataset of full text papers and reduced this to a final dataset of studies, resolving disagreements by discussion. Bilingual academic colleagues translated non-English papers and extracted data in collaboration with one of the research team. To identify recently published papers two researchers independently citation tracked the final dataset of studies in Google Scholar. Reference lists of the final dataset and other key references were also scanned.

\section{Quantitative data extraction and analysis}

Properties of included studies were tabulated on an Excel spreadsheet. A second researcher independently double checked the extraction of primary data from every study. Discrepancies were resolved by discussion. Where studies trialled multiple models with minimal difference in the number of risk factors, a judgment was made to extract data from the authors' preferred models or (if no preferences were stated in the paper) the ones judged by two researchers to be the most complete in presentation of data or statistical robustness. Data extraction covered characteristics of the population (age, sex, ethnicity, etc), size and duration of study, completeness of follow-up, method of diagnosing diabetes, details of internal or external validation, or both, and the components and metrics used by authors of these studies to express the properties of the score, especially their calibration and discrimination-for example, observed to predicted ratios, sensitivity and specificity, area under the receiver operating characteristic curve. We aimed to use statistical meta-analysis where appropriate and presented heterogeneous data in disaggregated form.

\section{Qualitative data extraction and analysis}

For the realist component of the review we extracted data and entered these on a spreadsheet under seven headings (box 1).
One researcher extracted these data from our final sample of papers and another checked a one third sample of these. Our research team discussed context-mechanism-outcome interactions hypothesised or implied by authors and reread the full sample of papers with all emerging mechanisms in mind to explore these further.

\section{Impact analysis}

We assessed the impact of each risk score in our final sample using three criteria: any description in the paper of use of the score beyond the population for whom it was developed and validated; number of citations of the paper in Google Scholar and number of these that described use of the score in an impact study; and critical appraisal of any impact studies identified on this citation track. In this phase we were guided by the question: what is the evidence that this risk score has been used in an intervention which improved (or sought to improve) outcomes for individuals at high risk of diabetes?

\section{Prioritising papers for reporting}

Given the large number of papers, statistical models, and risk scores in our final sample, we decided for clarity to highlight a small number of scores that might be useful to practising clinicians, public health specialists, or lay people. Adapting previous quality criteria for risk scores ${ }^{26}$ we favoured those that had external validation by a separate research team on a different population (generalisability), statistically significant calibration, a discrimination greater than 0.70 , and 10 or fewer components (usability).

\section{Results}

Figure $1 \Downarrow$ shows the flow of studies through the review. One hundred and fifteen papers were analysed in detail to produce a final sample of 43 . Of these 43 papers, 18 described the development of one or more risk models or scores, ${ }^{8} 27$ 36-51 17 described external validation of one or more models or scores on new populations, ${ }^{9} 101952-65$ and eight did both. ${ }^{76-72}$ In all, the 43 papers described 145 risk models and scores, of which 94 were selected for extraction of full data (the other 51 were minimally different, were not the authors' preferred model, or lacked detail or statistical robustness). Of the final sample of 94 risk models, 55 were derivations of risk models on a base population and 39 were external validations (of 14 different models) on new populations. Studies were published between 1993 and 2011, but most appeared in 2008-11 (fig $2 \Downarrow$ ). Indeed, even given that weaker cross sectional designs had been excluded, the findings suggest that new risk models and scores for diabetes are currently being published at a rate of about one every three weeks.

Table $1 \Downarrow$ gives full details of the studies in the sample, including the origin of the study, setting, population, methodological approach, duration, and how diabetes was diagnosed. The studies were highly heterogeneous. Models were developed and validated in 17 countries representing six continents (30 in Europe, 25 in North America, 21 in Asia, 8 in Australasia, 8 in the Middle East, 1 in South America, and 1 in Africa).

Comparisons across studies were problematic owing to heterogeneity of data and highly variable methodology, presentation techniques, and missing data. Cohorts ranged in size from 399 to 2.54 million. The same data and participants were often included in several different models in the same paper. Ten research populations were used more than once in different papers. ${ }^{9} 10273741424446-4951-56$ 63-66 7071 In total, risk models 


\author{
Box 1: Categories for data entry \\ Intended users \\ Authors' assumptions (if any) about who would use the risk score, on which subgroups or populations \\ Proposed action based on the score result \\ Authors' assumptions (if any) on what would be offered to people who score above the designated cut-off for high risk \\ Mechanism \\ Authors' hypothesised (or implied) mechanism by which use of the score might improve outcomes for patients \\ Descriptor \\ Authors' adjectives to describe their risk model or score \\ Relative advantage \\ Authors' claims for how and in what circumstances their model or score outperforms previous ones \\ Concerns \\ Authors' stated concerns about their model or score \\ Real world use, including citation tracking \\ Actual data in this paper or papers citing it on use of the score in the real world
}

were tested on 6.88 million participants, although this figure includes duplicate tests on the same dataset. Participants aged 18 to 98 were studied for periods ranging from 3.15 to 28 years. Completeness of follow-up ranged from $54 \%$ to $99 \%$ and incidence of diabetes across the time periods studied ranged from $1.3 \%$ to $20.9 \%$.

None of the models in the sample was developed on a cohort recruited prospectively for the express purpose of devising it. Rather, all authors used the more pragmatic approach of retrospectively studying a research dataset that had been assembled some years previously for a different purpose. Forty two studies excluded known diabetes in the inception cohort. Diagnosis of diabetes in a cohort at inception and completion of the study was done in different ways, including self report, patient questionnaires, clinician diagnosis, electronic code, codes from the International Classification of Diseases, disease or drug registers, diabetes drugs, dietary treatment, fasting plasma glucose levels, oral glucose tolerance test, and measurement of haemoglobin $\mathrm{A}_{1 \mathrm{c}}$. In some studies the method was not stated. Half the studies used different diagnostic tests at inception and completion of the study.

One third of the papers focused almost exclusively on the statistical properties of the models. Many of the remainder had a clinician (diabetologist or general practitioner) as coauthor and included an (often short and speculative) discussion on how the findings might be applied in clinical practice. Three described their score as a "clinical prediction rule."45 5159

\section{Quantitative findings}

Table $2 \Downarrow$ gives details of the components of the 94 risk models included in the final sample and their statistical properties-including (where reported) their discrimination, calibration, sensitivity, specificity, positive and negative predictive value, and area under the receiver operating characteristic curve. Many papers offered additional sophisticated statistical analysis, although there was no consistency in the approach used or statistical tests.

Heterogeneity of data (especially demographic and ethnic diversity of validation cohorts and different score components) in the primary studies precluded formal meta-analysis.

All 94 models presented a combination of risk factors as significant in the final model, and different models weighted different components differently. The number of components in a single risk score varied from 3 to $14(\mathrm{n}=84$, mean 7.8, SD 2.6). The seven risk scores that were classified as having high potential for use in practice offered broadly similar components and had similar discriminatory properties (area under receiver operating characteristic curve $0.74-0.85$, table 4 ). Overall, the areas under the receiver operating characteristic curve ranged from 0.60 to 0.91 . Certain components used in some models (for example, biomarkers) are rarely available in some pathology laboratories and potentially too expensive for routine use. Some models that exhibited good calibration and discrimination on the internal validation cohort performed much less well when tested on an external cohort, ${ }^{62}{ }^{67}$ suggesting that the initial model may have been over-fitted by inclusion of too many variables that had only minor contributions to the total risk. ${ }^{73}$ Although this study did not seek out genetic components, those studies that had included genetic markers alongside sociodemographic and clinical data all found that the genetic markers added little or nothing to the overall model. ${ }^{9} 103650$

Reporting of statistical data in some studies was incomplete-for example, only 40 of the 94 models quantified any form of calibration statistic. Forty three presented sensitivity and specificity, 27 justified the rationale for cut-off points, 22 presented a positive predictive value, 19 presented a negative predictive value, and 26 made some attempt to indicate the percentage of the population that would need clinical follow-up or testing if they scored as "high risk." Some models performed poorly-for example, there was a substantial gap between expected and observed numbers of participants who developed diabetes over the follow-up period. The false positive and false negative rates in many risk scores raised questions about their utility in clinical practice (for example, positive predictive values ranged from $5 \%$ to $42 \%$, negative predictive values from $88 \%$ to $99 \%$ ). However, some scores were designed as non-invasive preliminary instruments, with a recommended second phase involving a blood test. ${ }^{73} 5253555865$

Risk models and scores tended to "morph" when they were externally validated because research teams dropped components from the original (for example, if data on these were not available), added additional components (for example, to compensate for missing categories), or modified what counted in a particular category (for example, changing how ethnicity was classified); in some cases these modifications were not clarified. A key dimension of implementation is appropriate 
adaptation to a new context. It was considered that this did not negate the external validation.

\section{Qualitative findings}

Table $3 \Downarrow$ provides the qualitative findings from the risk scores. Of the 43 papers in the full sample, three did not recommend use of the model tested because the authors believed it had no advantage over existing ones. ${ }^{50}{ }^{560}$ Authors of the other 40 papers considered that at least one of their scores should be adopted and used, and to justify this made various claims. The commonest adjective used by authors to describe their score was "simple" (26 of 43); others mentioned "low cost," "easily implemented," "feasible," and "convenient."

Sixteen of the 43 studies that recommended use of a particular risk model or score did not designate an intended user for it. Some authors assigned agency to a risk score-that is, they stated, perhaps inadvertently, that the score itself had the potential to prevent diabetes, change behaviour, or reduce health inequalities. Although most authors did state an intended target group, this was usually given in vague terms, such as "the general population" or "individuals who are likely to develop diabetes." Eleven of the 43 papers gave a clear statement of what intervention might be offered, by whom, to people who scored above the cut-off for high risk; the other papers made no comment on this or used vague terms such as "preventive measures," without specifying by whom these would be delivered.

In all, authors of the papers in the full sample either explicitly identified or appeared to presume 10 mechanisms (box 2) by which, singly or in combination, use of the diabetes risk score might lead to improved patient outcomes (see table 3 ).

Risk models and scores had been developed in a range of health systems. Differences in components could be explained partly in terms of their intended context of use. For example, the QDScore, intended for use by general practitioners, was developed using a database of electronic records of a nationally representative sample of the UK general practice population comprising 2.5 million people. The QDScore is composed entirely of data items that are routinely recorded on general practice electronic records (including self assigned ethnicity, a deprivation score derived from the patient's postcode, and clinical and laboratory values). ${ }^{8}$ Another score, also intended to be derived from electronic records but in a US health maintenance organisation (covering people of working age who are in work), has similar components to the QDScore except that ethnicity and socioeconomic deprivation are not included. In contrast, the FINDRISC score was developed as a population screening tool intended for use directly by lay people; it consists of questions on sociodemographic factors and personal history along with waist circumference but does not include clinical or laboratory data; high scorers are prompted to seek further advice from a clinician. ${ }^{52}$ Such a score makes sense in many parts of Finland and also in the Netherlands where health and information literacy rates are high, but would be less fit for purpose in a setting where these were low.

\section{Prioritising scores for practising clinicians}

Table $4 \Downarrow$ summarises the properties of seven validated diabetes risk scores which we judged to be the most promising for use in clinical or public health practice. The judgments on which this selection was based were pragmatic; other scores not listed in table 4 (also see tables 1 and 2) will prove more fit for purpose in certain situations and settings. One score that has not yet been externally validated was included in table 4 because it is the only score already being incentivised in a national diabetes prevention policy. ${ }^{23}$

\section{Studies of impact of risk scores on patient outcomes}

None of the 43 papers that validated one or more risk scores described the actual use of that score in an intervention phase. Furthermore, although these papers had been cited by a total of 1883 (range 0-343, median 12) subsequent papers, only nine of those 1883 papers (table $5 \Downarrow$ ) described application and use of the risk score as part of an impact study aimed at changing patient outcomes. These covered seven studies, of which (to date) three have reported definitive results. All three reported positive changes in individual risk factors, but surprisingly none recalculated participants' risk scores after the intervention period to see if they had changed. While one report on the ongoing FIN-D2D study suggests that incident diabetes has been reduced in "real world" (non-trial) participants who were picked up using a diabetes risk score and offered a package of preventive care, ${ }^{74}$ this is a preliminary and indirect finding based on drug reimbursement claims, and no actual data are given in the paper. With that exception, no published impact study on a diabetes risk score has yet shown a reduction in incident diabetes.

\section{Discussion}

Numerous diabetes risk scores now exist based on readily available data and provide a good but not perfect estimate of the chance of an adult developing diabetes in the medium term future. A few research teams have undertaken exemplary development and validation of a robust model, reported its statistical properties thoroughly, and followed through with studies of impact in the real world.

\section{Limitations of included studies}

We excluded less robust designs (especially cross sectional studies). Nevertheless, included studies were not entirely free from bias and confounding. This is because the "pragmatic" use of a previously assembled database or cohort brings an inherent selection bias (for example, the British Regional Heart Study cohort was selected to meet the inclusion criteria for age and comorbidity defined by its original research team and oriented to research questions around cardiovascular disease; the population for the QDScore is drawn from general practice records and hence excludes those not registered with a general practitioner).

Most papers in our sample had one or more additional limitations. They reported models or scores that required collection of data not routinely available in the relevant health system; omitted key statistical properties such as calibration and positive and negative predictive values that would allow a clinician or public health commissioner to judge the practical value of the score; or omitted to consider who would use the score, on whom, and in what circumstances. We identified a mismatch between the common assumption of authors who develop a risk model (that their "simple" model can now be taken up and used) and the actual uptake and use of such models (which seems to happen very rarely). However, there has recently been an encouraging - if limited — shift in emphasis from the exclusive pursuit of statistical elegance (for example, maximising area under the receiver operating curve) to undertaking applied research on the practicalities and outcomes of using diabetes risk scores in real world prevention programmes. 


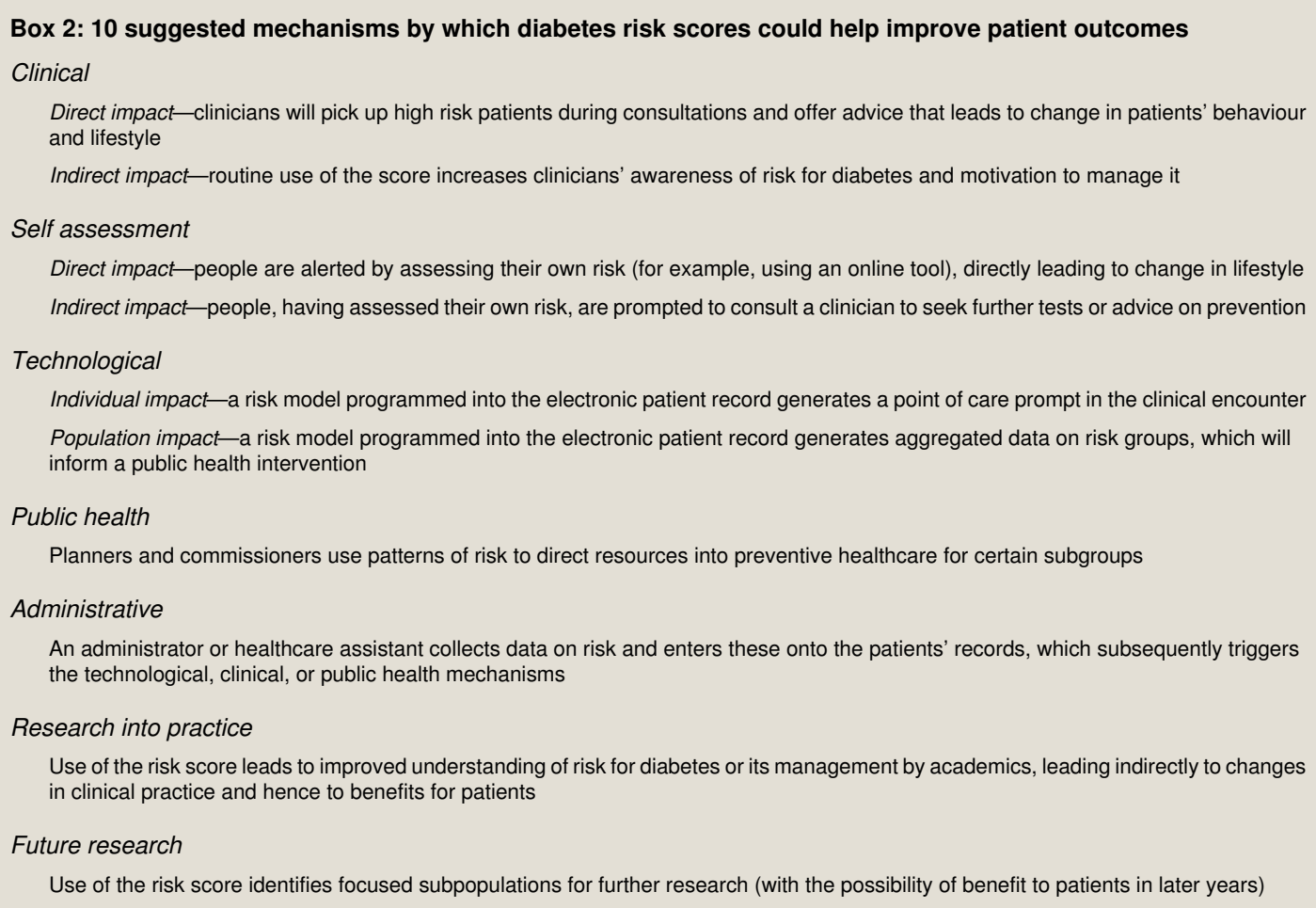

\section{Strengths and limitations of the review}

The strengths of this review are our use of mixed methodology, orientation to patient relevant outcomes, extraction and double checking of data by five researchers, and inclusion of a citation track to identify recently published studies and studies of impact. We applied both standard systematic review methods (to undertake a systematic and comprehensive search, translate all non-English texts, and extract and analyse quantitative data) and realist methods (to consider the relation between the components of the risk score, the context in which it was intended to be used, and the mechanism by which it might improve outcomes for patients).

The main limitation of this review is that data techniques and presentation in the primary studies varied so much that it was problematic to determine reasonable numerators and denominators for many of the calculations. This required us to make pragmatic decisions to collate and present data as fairly and robustly as possible while also seeking to make sense of the vast array of available risk scores to the general medical reader. We recognise that the final judgment on which risk scores are, in reality, easy to use will lie with the end user in any particular setting. Secondly, authors of some of the primary studies included in this review were developing a local tool for local use and made few or no claims that their score should be generalised elsewhere. Yet, the pioneers of early well known risk score ${ }^{49}{ }^{68}$ have occasionally found their score being applied to other populations (perhaps ethnically and demographically different from the original validation cohort), their selection of risk factors being altered to fit the available categories in other datasets, and their models being recalibrated to provide better goodness of fit. All this revision and recalibration to produce "new" scores makes the systematic review of such scores at best an inexact science.

\section{Why did we not recommend a "best" risk score?}

We have deliberately not selected a single, preferred diabetes risk score. There is no universal ideal risk score, as the utility of any score depends not merely on its statistical properties but also on its context of use, which will also determine which types of data are available to be included. ${ }^{75}{ }^{76}$ Even when a risk model has excellent discrimination (and especially when it does not) the trade-off between sensitivity and specificity plays out differently depending on context. Box 3 provides some questions to ask when selecting a diabetes risk score.

\section{Risk scores as complex interventions}

Our finding that diabetes risk scores seem to be used rarely can be considered in the light of the theoretical literature on diffusion of innovation. As well as being a statistical model, a risk score can be thought of as a complex, technology based innovation, the incorporation of which into business as usual (or not) is influenced by multiple contextual factors including the attributes of the risk score in the eyes of potential adopters (relative advantage, simplicity, and ease of use); adopters' concerns (including implications for personal workload and how to manage a positive score); their skills (ability to use and interpret the technology); communication and influence (for example, whether key opinion leaders endorse it); system antecedents (including a healthcare organisation's capacity to embrace new technologies, workflows, and ways of working); and external influences (including policy drivers, incentive structures, and competing priorities). ${ }^{77} 78$

\section{Challenges associated with risk scores in use}

While the developers of most diabetes risk scores are in little doubt about their score's positive attributes, this confidence seems not to be shared by practitioners, who may doubt the accuracy of the score or the efficacy of risk modification strategies, or both. Measuring diabetes risk competes for practitioners' attention with a host of other tasks, some of which 


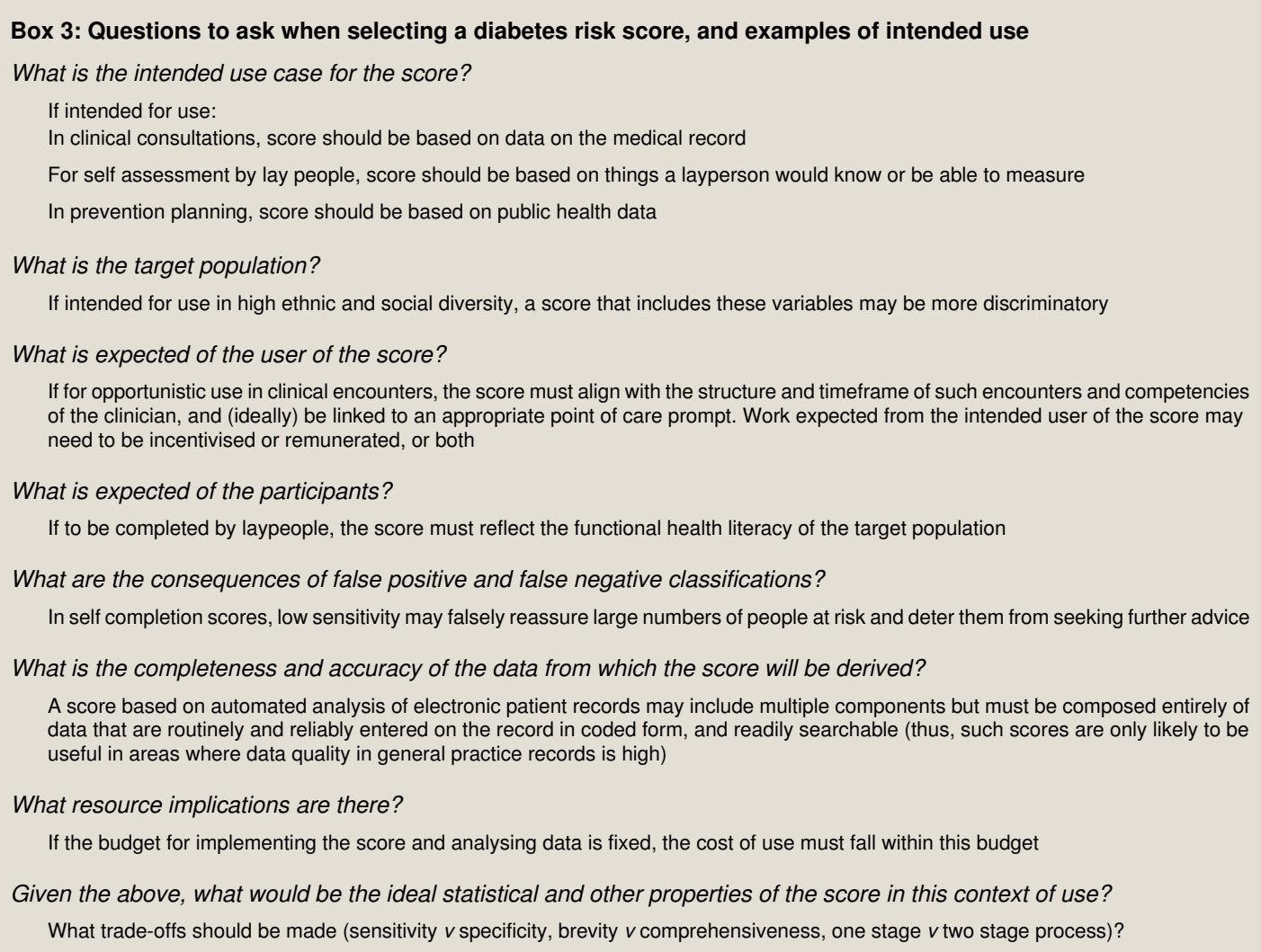

bring financial and other rewards. At the time of writing, few opinion leaders in diabetes seem to be promoting particular scores or the estimation of diabetes risk generally-perhaps because, cognisant of the limited impacts shown to date (summarised in table 5), they are waiting for further evidence of whether and how use of the risk score improves outcomes. Indeed, the utility of measuring diabetes risk in addition to cardiovascular risk is contested within the diabetes research community. ${ }^{79}$ In the United Kingdom, the imminent inclusion of an application for calculating QDScore on EMIS, the country's most widely used general practice computer system, may encourage its use in the clinical encounter. But unless the assessment of diabetes risk becomes part of the UK Quality and Outcomes Framework, this task may continue to be perceived as low priority by most general practitioners. Given current evidence, perhaps this judgment is correct. Furthermore, the low positive predictive values may spell trouble for commissioners. Identifying someone as "[possibly] high risk" will inevitably entail a significant cost in clinical review, blood tests, and (possibly) intervention and follow-up. Pending the results of ongoing impact studies, this may not be the best use of scarce resources.

Delivering diabetes prevention in people without any disease requires skills that traditionally trained clinicians may not possess. ${ }^{80} \mathrm{We}$ know almost nothing about the reach, uptake, practical challenges, acceptability, and cost of preventive interventions in high risk groups in different settings. ${ }^{12}$ The relative benefit of detecting and targeting high risk people rather than implementing population-wide diabetes prevention strategies is unknown. ${ }^{13}$ Effective prevention and early detection of diabetes are likely to require strengthening of health systems and development of new partnerships among the clinicians, community based lifestyle programmes, and healthcare funders. ${ }^{81}$

\section{Mechanisms by which risk scores might have impact}

Although most authors of papers describing diabetes risk scores have hypothesised (or seem to have assumed) a clinical mechanism of action (that the score would be used by the individual's clinician to target individual assessment and advice), the limited data available on impact studies (see table 5) suggest that a particularly promising area for further research is interventions that prompt self assessment-that is, laypeople measuring their own risk of diabetes. The preliminary findings from the impact studies covered in this review also suggest that not everyone at high risk is interested in coming forward for individual preventive input, nor will they necessarily stay the course of such input. It follows that in areas where aggregated data from electronic patient records are available, the diabetes risk scores may be used as a population prediction tool-for example, to produce small area statistics (perhaps as pictorial maps) of diabetes risk across a population, thereby allowing targeted design and implementation of community level public health interventions. ${ }^{82}$ Small area mapping of diabetes risk may be a way of operationalising the recently published guidance on diabetes prevention from the National Institute for Health and Clinical Excellence, which recommends the use of "local and national tools ... to identify local communities at high risk of developing diabetes to assess their specific needs." 83

\section{Towards an impact oriented research agenda for risk scores}

We recommend that funding bodies and journal editors help take this agenda forward by viewing the risk score in use as a complex intervention and encouraging more applied research studies in which real people identified as at "high risk" using a particular risk score are offered real interventions; success in risk score development is measured in terms of patient relevant intermediate outcomes (for example, change in risk score) and 
final outcomes (incident diabetes and related morbidity) rather than in terms of the statistical properties of the tool; a qualitative component (for example, process evaluation, organisational case study, patient's experience of lifestyle modification) explores both facilitators and barriers of using the score in a real world setting; and an economic component evaluates cost and cost effectiveness.

\section{Conclusion}

Millions of participants across the world have already participated in epidemiological studies aimed at developing a diabetes risk score. An extensive menu of possible scores are now available to those who seek to use them clinically or to validate them in new populations, none of which is perfect but all of which have strengths. Nevertheless, despite the growing public health importance of type 2 diabetes and the enticing possibility of prevention for those at high risk of developing it, questions remain about how best to undertake risk prediction and what to do with the results. Appropriately, the balance of research effort is now shifting from devising new risk scores to exploring how best to use those we already have.

We thank Helen Elwell, librarian at the British Medical Association Library, for help with the literature search; Samuel Rigby for manually removing duplicates; and Sietse Wieringa, Kaveh Memarzadeh, and Nicholas Swetenham for help with translation of non-English papers. $B M J$ reviewers Wendy Hu and John Furler provided helpful comments on an earlier draft.

Contributors: DN conceptualised the study, managed the project, briefed and supported all researchers, assisted with developing the search strategy and ran the search, scanned all titles and abstracts, extracted quantitative data on half the papers, citation tracked all papers, checked a one third sample of the qualitative data extraction, and cowrote the paper. TG conceptualised the qualitative component of the study, extracted qualitative data on all papers, independently citation tracked all papers, and led on writing the paper. RM independently scanned all titles and abstracts of the electronic search, extracted quantitative data from some papers, assisted with other double checking, and helped revise drafts of the paper. TD helped revise and refine the study aims, independently double checked quantitative data extraction from all papers, and helped revise drafts of the paper. CM advised on systematic review methodology, helped develop the search strategy, extracted quantitative data from some papers, and helped revise drafts of the paper. TG acts as guarantor.

Funding: This study was funded by grants from Tower Hamlets, Newham, and City and Hackney primary care trusts, by a National Institute of Health Research senior investigator award for TG, and by internal funding for staff time from Barts and the London School of Medicine and Dentistry. The funders had no input into the selection or analysis of data or the content of the final manuscript.

Competing interests: All authors have completed the ICMJE uniform disclosure form at www.icmje.org/coi_disclosure.pdf (available on request from the corresponding author) and declare: no support from any organisation for the submitted work; no financial relationships with any organisations that might have an interest in the submitted work in the previous three years; and no other relationships or activities that could appear to have influenced the submitted work.

Ethical approval: Not required.

Data sharing: No additional data available.

Shaw JE, Sicree RA, Zimmet PZ. Global estimates of the prevalence of diabetes for 2010 and 2030. Diabetes Res Clin Pract 2010;87:4-14.

2 Holman N, Forouhi NG, Goyder E, Wild SH. The Association of Public Health Observatories (APHO) Diabetes Prevalence Model: estimates of total diabetes prevalence for England, 2010-2030. Diabetic Med 2011;28:575-82.
3 National Diabetes Clearinghouse. National Diabetes Statistics 2011. National Institute of Health, USA. http://diabetes.niddk.nih.gov/dm/pubs/statistics/\#Diagnosed20.

4 Yang SH, Dou KF, Song WJ. Prevalence of diabetes among men and women in China. N Engl J Med 2010;362:2425-6.

5 Saadi H, Carruthers SG, Nagelkerke N, Al-Maskari F, Afandi B, Reed R, et al. Prevalence of diabetes mellitus and its complications in a population-based sample in Al Ain, United Arab Emirates. Diabetes Res Clin Pract 2007;78:369-77.

6 Williamson DF, Vinicor F, Bowman BA. Primary prevention of type 2 diabetes mellitus by lifestyle intervention: implications for health policy. Ann Intern Med 2004;140:951-7.

7 Aekplakorn W, Bunnag P, Woodward M, Sritara P, Cheepudomwit S, Yamwong S, et al. A risk score for predicting incident diabetes in the Thai population. Diabetes Care 2006;29:1872-7.

8 Hippisley-Cox J, Coupland C, Robson J, Sheikh A, Brindle P. Predicting risk of type 2 diabetes in England and Wales: prospective derivation and validation of QDScore. BMJ 2009;338:b880.

9 Meigs JB, Shrader P, Sullivan LM, McAteer JB, Fox CS, Dupuis J, et al. Genotype score in addition to common risk factors for prediction of type 2 diabetes. N Engl J Med 2008;359:2208-9.

10 Talmud PJ, Hingorani AD, Cooper JA, Marmot MG, Brunner EJ, Kumari M, et al. Utility of genetic and non-genetic risk factors in prediction of type 2 diabetes: Whitehall II prospective cohort study. BMJ 2010;340:b4838.

11 Park KS. The search for genetic risk factors of type 2 diabetes mellitus. Diabetes Metab J 2011;35:12-22.

12 Simmons RK, Unwin N, Griffin SJ. International Diabetes Federation: an update of the evidence concerning the prevention of type 2 diabetes. Diabetes Res Clin Pract 2010;87:143-9.

13 Yates T, Davies M, Khunti K. Preventing type 2 diabetes: can we make the evidence work? Postgrad Med J 2009;85:475-80.

14 Simmons RK, Echouffo-Tcheugui JB, Griffin SJ. Screening for type 2 diabetes: an update of the evidence. Diabetes Obes Metab 2010;12:838-44.

15 Gillies CL, Lambert PC, Abrams KR, Sutton AJ, Cooper NJ, Hsu RT, et al. Different strategies for screening and prevention of type 2 diabetes in adults: cost effectiveness analysis. BMJ 2008:336:1180-5.

16 Pan XR, Li GW, Hu YH, Wang JX, Yang WY, An ZX, et al. Effects of diet and exercise in preventing NIDDM in people with impaired glucose tolerance. The Da Qing IGT and Diabetes Study. Diabetes Care 1997;20:537-44.

17 Tuomilehto J, Lindstrom J. The major diabetes prevention trials. Curr Diab Rep 2003;3:115-22.

18 Knowler WC, Barrett-Connor E, Fowler SE, Hamman RF, Lachin JM, Walker EA, et al. Reduction in the incidence of type 2 diabetes with lifestyle intervention or metformin. $N$ Engl J Med 2002;346:393-403.

19 Mann DM, Bertoni AG, Shimbo D, Carnethon MR, Chen H, Jenny NS, et al. Comparative validity of 3 diabetes mellitus risk prediction scoring models in a multiethnic US cohort: the Multi-Ethnic Study of Atherosclerosis. Am J Epidemiol 2010;171:980-8.

20 Tuomilehto J, Lindstrom J, Hellmich M, Lehmacher W, Westermeier T, Evers T, et al. Development and validation of a risk-score model for subjects with impaired glucose tolerance for the assessment of the risk of type 2 diabetes mellitus-The STOP-NIDDM risk-score. Diabetes Res Clin Pract 2010;87:267-74.

21 National Institute for Health and Clinical Excellence. Lipid modification. 2011. www.nice. org.uk/nicemedia/live/11982/40675/40675.pdf.

22 McElduff P, Lyratzopoulos G, Edwards R, Heller RF, Shekelle P, Roland M. Will changes in primary care improve health outcomes? Modelling the impact of financial incentives introduced to improve quality of care in the UK. Qual Saf Health Care 2004;13:191-7.

23 Anon. Type 2 diabetes risk evaluation for men and women aged 40-49 years at high risk of type 2 diabetes. MBS item 713. 2011. www.agpn.com.au/_data/assets/pdf_file/0015/ 15009/20081126 brf practice-detailing-card-item-713.pdf.

24 Sytkowski PA, Kannel WB, D'Agostino RB. Changes in risk factors and the decline in mortality from cardiovascular disease. The Framingham Heart Study. N Engl J Med 1990;322:1635-41.

25 Moons KG, Royston P, Vergouwe $Y$, Grobbee DE, Altman DG. Prognosis and prognostic research: what, why, and how? BMJ 2009;338:b375.

26 Altman DG, Vergouwe Y, Royston P, Moons KG. Prognosis and prognostic research: validating a prognostic model. BMJ 2009;338:b605.

27 Wannamethee SG, Papacosta O, Whincup PH, Thomas MC, Carson C, Lawlor DA, et al. The potential for a two-stage diabetes risk algorithm combining non-laboratory-based scores with subsequent routine non-fasting blood tests: results from prospective studies in older men and women. Diabet Med 2011;28:23-30.

28 Wareham NJ, Griffin SJ. Risk scores for predicting type 2 diabetes: comparing axes and spades. Diabetologia 2011:54:994-5.

29 Royston P, Moons KG, Altman DG, Vergouwe Y. Prognosis and prognostic research: developing a prognostic model. BMJ 2009;338:b604.

30 Moons KG, Altman DG, Vergouwe Y, Royston P. Prognosis and prognostic research: application and impact of prognostic models in clinical practice. BMJ 2009;338:b606.

1 Pawson R, Tilley N. Realistic evaluation. Sage, 1997.

32 Kahn KS, Kunz R, Kleijnen J, Antes G. Systematic reviews to support evidence-based medicine, 2nd ed. Royal Society of Medicine, 2011.

33 Centre for Reviews and Dissemination. Systematic Reviews: centre for reviews and dissemination guidance for undertaking reviews in health care. York Publishing Services. 2011. www.york.ac.uk/inst/crd/pdt/Systematic_Reviews.pdf.

34 Pawson R, Greenhalgh T, Harvey G, Walshe K. Realist review-a new method of systematic review designed for complex policy interventions. J Health Serv Res Policy 2005;10(suppl 1):21-34.

35 Greenhalgh T, Wong G, Westhorp G, Pawson R, on behalf of the RAMESES study group. Protocol-realist and meta-narrative evidence synthesis: evolving standards (RAMESES). BMC Med Res Methodol 2011;11:115

36 Balkau B, Lange C, Fezeu L, Tichet J, de Lauzon-Guillain B, Czernichow S, et al. Predicting diabetes: clinical, biological, and genetic approaches: data from the Epidemiological Study on the Insulin Resistance Syndrome (DESIR). Diabetes Care 2008:31:2056-61.

37 Chen L, Magliano DJ, Balkau B, Colagiuri S, Zimmet PZ, Tonkin AM, et al. AUSDRISK: an Australian type 2 diabetes risk assessment tool based on demographic, lifestyle and simple anthropometric measures. Med J Aust 2010;192:197-202.

38 Chuang SY, Yeh WT, Wu YL, Chang HY, Pan WH, Tsao CK. Prediction equations and point system derived from large-scale health check-up data for estimating diabetic risk in the Chinese population of Taiwan. Diabetes Res Clin Pract 2011;92:128-36. 


\section{What is already known on this topic}

The many known risk factors for type 2 diabetes can be combined in statistical models to produce risk scores

\section{What this study adds}

Dozens of risk models and scores for diabetes have been developed and validated in different settings Sociodemographic and clinical data were much better predictors of diabetes risk than genetic markers Research on this topic is beginning to shift from developing new statistical risk models to considering the use and impact of risk scores in the real world

39 Gao WG, Qiao Q, Pitkaniemi J, Wild S, Magliano D, Shaw J, et al. Risk prediction models for the development of diabetes in Mauritian Indians. Diabet Med 2009;26:996-1002.

40 Joseph J, Svartberg J, Njolstad I, Schirmer H. Incidence of and risk factors for type-2 diabetes in a general population: the Tromso Study. Scand J Public Health 2010;38:768-75

41 Kahn HS, Cheng YJ, Thompson TJ, Imperatore G, Gregg EW. Two risk-scoring systems for predicting incident diabetes mellitus in US adults age 45 to 64 years. Ann Intern Med 2009;150:741-51.

42 Kolberg JA, Jorgensen T, Gerwien RW, Hamren S, McKenna MP, Moler E, et al. Development of a type 2 diabetes risk model from a panel of serum biomarkers from the Inter99 cohort. Diabetes Care 2009;32:1207-12.

43 Liu M, Pan C, Jin M. A Chinese diabetes risk score for screening of undiagnosed diabetes and abnormal glucose tolerance. Diabetes Technol Ther 2011;13:501-7.

44 Mehrabi Y, Sarbakhsh P, Hadaegh F, Khadem-Maboudi A. Prediction of diabetes using logic regression. Iran J Endocrinol Metab 2010;12:16-24.

45 Rathmann W, Kowall B, Heier M, Herder C, Holle R, Thorand B, et al. Prediction models for incident type 2 diabetes mellitus in the older population: KORA S4/F4 cohort study. Diabet Med 2010;27:1116-23

46 Schmidt MI, Duncan BB, Bang H, Pankow JS, Ballantyne CM, Golden SH, et al. Identifying individuals at high risk for diabetes: the Atherosclerosis Risk in Communities study. Diabetes Care 2005;28:2013-8.

47 Schulze MB, Weikert C, Pischon T, Bergmann MM, Al-Hasani H, Schleicher E, et al. Use of multiple metabolic and genetic markers to improve the prediction of type 2 diabetes: the EPIC-Potsdam Study. Diabetes Care 2009;32:2116-9.

48 Stern MP, Morales PA, Valdez RA, Monterrosa A, Haffner SM, Mitchell BD, et al. Predicting diabetes. Moving beyond impaired glucose tolerance. Diabetes 1993:42:706-14.

49 Stern MP, Williams K, Haffner SM. Identification of persons at high risk for type 2 diabetes mellitus: do we need the oral glucose tolerance test? Ann Intern Med 2002;136:575-81.

50 von Eckardstein A, Schulte H, Assmann G. Risk for diabetes mellitus in middle-aged Caucasian male participants of the PROCAM study: implications for the definition of impaired fasting glucose by the American Diabetes Association. Prospective Cardiovascular Munster. J Clin Endocrinol Metab 2000;85:3101-8.

51 Wilson PW, Meigs JB, Sullivan L, Fox CS, Nathan DM, D'Agostino RB Sr. Prediction of incident diabetes mellitus in middle-aged adults: the Framingham Offspring Study. Arch Intern Med 2007;167:1068-74

52 Alssema M, Feskens EJ, Bakker SJ, Gansevoort RT, Boer JM, Heine RJ, et al. [Finnish questionnaire reasonably good predictor of the incidence of diabetes in The Netherlands]. Ned Tijdschr Geneeskd 2008;152:2418-24.

53 Alssema M, Vistisen D, Heymans MW, Nijpels G, Glumer C, Zimmet PZ, et al. The Evaluation of Screening and Early Detection Strategies for Type 2 Diabetes and Impaired Glucose Tolerance (DETECT-2) update of the Finnish diabetes risk score for prediction of incident type 2 diabetes. Diabetologia 2011;54:1004-12.

54 Bozorgmanesh M, Hadaegh F, Azizi F. Transportability of the updated diabetes prediction model from Atherosclerosis Risk in Communities Study to a Middle Eastern adult population: community-based cohort study. Acta Diabetol 2010; doi: 10.1007/s00592 010-0241-1.

55 Bozorgmanesh M, Hadaegh F, Zabetian A, Azizi F. San Antonio heart study diabetes prediction model applicable to a Middle Eastern population? Tehran glucose and lipid study. Int J Public Health 2010;55:315-23.

56 Cameron AJ, Magliano DJ, Zimmet PZ, Welborn TA, Colagiuri S, Tonkin AM, et al. The metabolic syndrome as a tool for predicting future diabetes: the AusDiab study. $J$ Intern Med 2008:264:177-86

57 Collins GS, Altman DG. External validation of QDSCORE((R)) for predicting the 10-year risk of developing type 2 diabetes. Diabet Med 2011;28:599-607.

58 Guerrero-Romero F, Rodriguez-Moran M. [Validation of an instrument for screening cases of type 2 diabetes and monitoring at-risk individuals in Mexico]. Rev Panam Salud Publica 2010;27:181-6.

59 Kanaya AM, Wassel Fyr CL, de Rekeneire N, Shorr RI, Schwartz AV, Goodpaster BH, et al. Predicting the development of diabetes in older adults: the derivation and validation of a prediction rule. Diabetes Care 2005;28:404-8.

60 Mainous AG, III, Diaz VA, Everett CJ. Assessing risk for development of diabetes in young adults. Ann Fam Med 2007:5:425-9.

61 McNeely MJ, Boyko EJ, Leonetti DL, Kahn SE, Fujimoto WY. Comparison of a clinical model, the oral glucose tolerance test, and fasting glucose for prediction of type 2 diabetes risk in Japanese Americans. Diabetes Care 2003;26:758-63.

62 Nichols GA, Brown JB. Validating the Framingham Offspring Study equations for predicting incident diabetes mellitus. Am J Manag Care 2008;14:574-80.

63 Rahman M, Simmons RK, Harding AH, Wareham NJ, Griffin SJ. A simple risk score identifies individuals at high risk of developing type 2 diabetes: a prospective cohort study. Fam Pract 2008:25:191-6.

64 Urdea M, Kolberg J, Wilber J, Gerwien R, Moler E, Rowe M, et al. Validation of multimarker model for assessing risk of type 2 diabetes from a five-year prospective study of 6784 Danish people (Inter99). J Diabetes Sci Technol 2009;3:748-55.

65 Wannamethee SG, Shaper AG, Lennon L, Morris RW. Metabolic syndrome vs Framingham Risk Score for prediction of coronary heart disease, stroke, and type 2 diabetes mellitus. Arch Intern Med 2005:165:2644-50.

66 Bozorgmanesh M, Hadaegh F, Ghaffari S, Harati H, Azizi F. A simple risk score effectively predicted type 2 diabetes in Iranian adult population: population-based cohort study. Eur $J$ Public Health 2011;21:554-9.

67 Chien K, Cai T, Hsu H, Su T, Chang W, Chen M, et al. A prediction model for type 2 diabetes risk among Chinese people. Diabetologia 2009;52:443-50.
68 Lindstrom J, Tuomilehto J. The diabetes risk score: a practical tool to predict type 2 diabetes risk. Diabetes Care 2003;26:725-31.

69 Rosella LC, Manuel DG, Burchill C, Stukel TA. A population-based risk algorithm for the development of diabetes: development and validation of the Diabetes Population Risk Tool (DPoRT). J Epidemiol Community Health 2011;65:613-20.

70 Schulze MB, Hoffmann K, Boeing H, Linseisen J, Rohrmann S, Mohlig M, et al. An accurate risk score based on anthropometric, dietary, and lifestyle factors to predict the development of type 2 diabetes. Diabetes Care 2007;30:510-5.

71 Simmons RK, Harding AH, Wareham NJ, Griffin SJ. Do simple questions about diet and physical activity help to identify those at risk of type 2 diabetes? Diabet Med 2007;24:830-5.

72 Sun F, Tao Q, Zhan S. An accurate risk score for estimation 5-year risk of type 2 diabetes based on a health screening population in Taiwan. Diabetes Res Clin Pract 2009;85:228-34.

73 Harrell F. Regression modelling strategies with applications to linear models, logistic regression and survival analysis . Springer-Verlag, 2001.

74 Lindstrom J, Absetz P, Hemio K, Peltomaki P, Peltonen M. Reducing the risk of type diabetes with nutrition and physical activity - efficacy and implementation of lifestyle interventions in Finland. Public Health Nutr 2010;13(6A):993-9.

75 Herman WH. Predicting risk for diabetes: choosing (or building) the right model. Ann Intern Med 2009;150:812-4.

76 Wright C, Dent T. Quality standards in risk prediction: summary of an expert meeting. PHG Foundation, 2011.www.phgfoundation.org

77 Greenhalgh T, Robert G, Macfarlane F, Bate P, Kyriakidou O, Peacock R. Diffusion of innovations in service organisations: systematic literature review and recommendations for future research. Milbank Q 2004;82:581-629.

78 Davis FD. Perceived usefulness, perceived ease of use, and user acceptance of information technology. MIS Quarterly 1989;13:319-40.

79 Chamnan P, Simmons RK, Jackson R, Khaw KT, Wareham NJ, Griffin SJ. Non-diabetic hyperglycaemia and cardiovascular risk: moving beyond categorisation to individual interpretation of absolute risk. Diabetologia 2011;54:291-9.

80 Saaristo T, Peltonen M, Keinanen-Kiukaanniemi S, Vanhala M, Saltevo J, Niskanen L, et al. National type 2 diabetes prevention programme in Finland: FIN-D2D. Int $J$ Circumpolar Health 2007;66:101-12.

81 Narayan KM, Williamson DF. Prevention of type 2 diabetes: risk status, clinic, and community. J Gen Intern Med 2010;25:154-7.

82 Stewart JE, Battersby SE, Lopez-De FA, Remington KC, Hardin JW, Mayfield-Smith K. Diabetes and the socioeconomic and built environment: geovisualization of disease prevalence and potential contextual associations using ring maps. Int $\mathrm{J}$ Health Geogr 2011;10:18

83 National Institute for Health and Clinical Excellence. Preventing type 2 diabetes-population and community interventions. 2011. www.nice.org.uk/guidance/ $\mathrm{PH} 35$.

84 Stone MA, Camosso-Stefinovic J, Wilkinson J, de Lusignan S, Hattersley AT, Khunti K. Incorrect and incomplete coding and classification of diabetes: a systematic review. Diabet Med 2010;27:491-7.

85 Rathmann W, Kowall B, Schulze MB. Development of a type 2 diabetes risk model from a panel of serum biomarkers from the Inter 99 cohort: response to Kolberg et al. Diabetes Care 2010;33:e28.

86 Stern M, Williams K, Eddy D, Kahn R. Validation of prediction of diabetes by the Archimedes model and comparison with other predicting models. Diabetes Care 2008:31:1670-1.

87 Colagiuri S, Vita P, Cardona-Morrell M, Singh MF, Farrell L, Milat A, et al. The Sydney Diabetes Prevention Program: a community-based translational study. BMC Public Health 2010;10:328.

88 Absetz P, Oldenburg B, Hankonen N, Valve R, Heinonen H, Nissinen A, et al. Type 2 diabetes prevention in the real world: three-year results of the GOAL lifestyle implementation trial. Diabetes Care 2009;32:1418-20.

89 Jallinoja P, Pajari P, Absetz P. Repertoires of lifestyle change and self-responsibility among participants in an intervention to prevent type 2 diabetes. Scand J Caring Sci 2008;22:455-62.

90 Kulzer B, Hermanns N, Gorges D, Schwarz P, Haak T. Prevention of diabetes self-management program (PREDIAS): effects on weight, metabolic risk factors, and behavioral outcomes. Diabetes Care 2009;32:1143-6.

91 Laatikainen T, Dunbar JA, Chapman A, Kilkkinen A, Vartiainen E, Heistaro S, et al. Prevention of type 2 diabetes by lifestyle intervention in an Australian primary health care setting: Greater Green Triangle (GGT) Diabetes Prevention Project. BMC Public Health 2007;7:249

92 Vermunt PW, Milder IE, Wielaard F, van Oers JA, Westert GP. An active strategy to identify individuals eligible for type 2 diabetes prevention by lifestyle intervention in Dutch primary care: the APHRODITE study. Fam Pract 2010;27:312-9.

Accepted: 5 October 2011

\section{Cite this as: BMJ 2011;343:d7163}

This is an open-access article distributed under the terms of the Creative Common Attribution Non-commercial License, which permits use, distribution, and reproduction in any medium, provided the original work is properly cited, the use is non commercial and is otherwise in compliance with the license. See: http://creativecommons.org/licenses/bync/2.0/ and http://creativecommons.org/licenses/by-nc/2.0/legalcode. 


\section{Tables}

\section{Table 1| Summary of $\mathbf{4 3}$ papers from which $\mathbf{9 4}$ diabetes risk models or scores were identified for systematic review

\begin{tabular}{|c|c|c|c|c|c|c|c|c|}
\hline Study* & Country & Name of study & $\begin{array}{l}\text { Name of risk } \\
\text { score }\end{array}$ & $\begin{array}{l}\text { Study design } \\
\text { and sampling } \\
\text { frame }\end{array}$ & $\begin{array}{l}\text { Why inception } \\
\text { cohort was } \\
\text { assembled }\end{array}$ & $\begin{array}{l}\text { Sample } \\
\text { size }\end{array}$ & $\begin{array}{c}\text { Duration: } \\
\text { mean (SD), } \\
\text { range (years), } \\
\text { or as reported }\end{array}$ & $\begin{array}{l}\text { Age: mean } \\
\text { (SD) or } \\
\text { range }\end{array}$ \\
\hline $\begin{array}{l}\text { Aekplakorn } 2006^{7} \\
\text { (two of six models } \\
\text { reported) }\end{array}$ & Thailand & $\begin{array}{l}\text { Electric } \\
\text { Generating } \\
\text { Authority of } \\
\text { Thailand Study }\end{array}$ & NS & $\begin{array}{l}\text { Power plant } \\
\text { workers: } \\
\text { cohort } \\
\text { derivation } \\
\text { study; and } \\
\text { cohort external } \\
\text { validation } \\
\text { study }\end{array}$ & $\begin{array}{l}\text { Study of vascular risk; } \\
\text { implicitly, study of } \\
\text { diabetes risk }\end{array}$ & $\begin{array}{l}3254 \\
2420\end{array}$ & $\begin{array}{l}12,1985-97 ; 5 \\
1998-2003\end{array}$ & $35-54$ \\
\hline
\end{tabular}

\begin{tabular}{|c|c|c|c|c|c|c|c|c|c|c|}
\hline $\begin{array}{l}\text { Alssema } 2008^{52} \\
\text { (two of three } \\
\text { models reported) }\end{array}$ & Netherlands & $\begin{array}{l}\text { Hoorn study, } \\
\text { PREVEND study }\end{array}$ & $\begin{array}{l}\text { Modified } \\
\text { FINDRISC for } \\
\text { Dutch population }\end{array}$ & $\begin{array}{l}\text { Cohort } \\
\text { external } \\
\text { validation } \\
\text { study, sample } \\
\text { NS }\end{array}$ & $\begin{array}{l}\text { Studies of glucose } \\
\text { tolerance; } \\
\text { cardiovascular } \\
\text { disease and renal } \\
\text { disease }\end{array}$ & $\begin{array}{l}2439 \\
3345\end{array}$ & $\begin{array}{l}6.4(0.5), \\
1989-98 ; 4.2 \\
(0.4), \\
1997-2003\end{array}$ & $\geq 45 ; 28-75$ & $\begin{array}{l}\text { Oral glucose } \\
\text { tolerance } \\
\text { test; fasting } \\
\text { plasma } \\
\text { glucose }\end{array}$ & NS \\
\hline $\begin{array}{l}\text { Alssema } 2011^{53} \\
\text { (two of three } \\
\text { models reported) }\end{array}$ & $\begin{array}{l}\text { Netherlands, } \\
\text { Denmark, } \\
\text { Sweden, UK, } \\
\text { Australia, } \\
\text { Mauritius }\end{array}$ & $\begin{array}{l}\text { DETECT-2 } \\
\text { (includes } \\
\text { Ausdiab, Hoorn, } \\
\text { Inter99, } \\
\text { MONICA, } \\
\text { Whitehall-II) }\end{array}$ & $\begin{array}{l}\text { Based on } \\
\text { FINDRISC }\end{array}$ & $\begin{array}{l}\text { Cohort } \\
\text { external } \\
\text { validation } \\
\text { study of } \\
\text { FINDRISC in } \\
\text { combined } \\
\text { samples from } \\
\text { five studies }\end{array}$ & NS & 18301 & $\begin{array}{l}4.8-5 \\
1986-2001\end{array}$ & $\begin{array}{l}\text { Ranged from } \\
46.3(7.8) \text { to } \\
60.3(6.9) \text { in } \\
\text { five studies }\end{array}$ & $\begin{array}{l}\text { Oral glucose } \\
\text { tolerance test }\end{array}$ & $\begin{array}{l}\text { Oral glucose } \\
\text { tolerance test }\end{array}$ \\
\hline $\begin{array}{l}\text { Balkau } 2008^{36} \\
\text { (both models } \\
\text { reported) }\end{array}$ & France & DESIR & NS & $\begin{array}{l}\text { Cohort } \\
\text { derivation } \\
\text { study in } \\
\text { volunteers for } \\
\text { free health } \\
\text { examinations } \\
\end{array}$ & $\begin{array}{l}\text { Study of insulin } \\
\text { resistance syndrome }\end{array}$ & $\begin{array}{l}1863 \\
\text { and } \\
1954\end{array}$ & $9(<1996)$ & $47(10)$ & NS & $\begin{array}{l}\text { Fasting } \\
\text { plasma } \\
\text { glucose, } \\
\text { diabetes } \\
\text { drugs }\end{array}$ \\
\hline $\begin{array}{l}\text { Bozorgmanesh } \\
2010^{54}\end{array}$ & Iran & $\begin{array}{l}\text { Tehran Lipid and } \\
\text { Glucose Study }\end{array}$ & $\begin{array}{l}\text { Modified ARIC } \\
\text { (Atherosclerosis } \\
\text { Risk In } \\
\text { Communities) }\end{array}$ & $\begin{array}{l}\text { Cohort } \\
\text { external } \\
\text { validation } \\
\text { study in } \\
\text { general } \\
\text { population }\end{array}$ & $\begin{array}{l}\text { Study of lipid and } \\
\text { glucose risk factors }\end{array}$ & 5018 & 6, 1999-2008 & $\begin{array}{l}\text { Men } 42.8 \\
(14.8) ; \\
\text { women } 40.7 \\
\text { (12.5) } \\
\end{array}$ & $\begin{array}{l}\text { Oral glucose } \\
\text { tolerance } \\
\text { test, fasting } \\
\text { plasma } \\
\text { glucose, } \\
\text { diabetes } \\
\text { drugs }\end{array}$ & $\begin{array}{l}\text { Oral glucose } \\
\text { tolerance } \\
\text { test, fasting } \\
\text { plasma } \\
\text { glucose, } \\
\text { diabetes } \\
\text { drugs }\end{array}$ \\
\hline $\begin{array}{l}\text { Bozorgmanesh } \\
2011^{66} \text { (all five } \\
\text { models reported) }\end{array}$ & Iran & $\begin{array}{l}\text { Tehran Lipid and } \\
\text { Glucose Study }\end{array}$ & NS & $\begin{array}{l}\text { Cohort } \\
\text { derivation } \\
\text { study, and } \\
\text { cohort external } \\
\text { validation } \\
\text { study, in } \\
\text { general } \\
\text { population }\end{array}$ & $\begin{array}{l}\text { Study of lipid and } \\
\text { glucose risk factors }\end{array}$ & 5018 & 6, 1999-2008 & $41.6(13.2)$ & $\begin{array}{l}\text { Oral glucose } \\
\text { tolerance } \\
\text { test, fasting } \\
\text { plasma } \\
\text { glucose, } \\
\text { diabetes } \\
\text { drugs }\end{array}$ & $\begin{array}{l}\text { Oral glucose } \\
\text { tolerance } \\
\text { test, fasting } \\
\text { plasma } \\
\text { glucose, } \\
\text { diabetes } \\
\text { drugs }\end{array}$ \\
\hline $\begin{array}{l}\text { Bozorgmanesh } \\
2010^{55} \text { (one of six } \\
\text { models reported) }\end{array}$ & Iran & $\begin{array}{l}\text { Tehran Lipid and } \\
\text { Glucose Study }\end{array}$ & $\begin{array}{l}\text { San Antonio } \\
\text { diabetes } \\
\text { prediction model }\end{array}$ & $\begin{array}{l}\text { Cohort } \\
\text { external } \\
\text { validation } \\
\text { study in } \\
\text { general } \\
\text { population }\end{array}$ & $\begin{array}{l}\text { Study of lipid and } \\
\text { glucose risk factors }\end{array}$ & 5018 & 6.3, 1999-2008 & $\begin{array}{l}\text { Men } 42.8 \\
(14.8) ; \\
\text { women } 40.7 \\
(12.5) \\
\end{array}$ & $\begin{array}{l}\text { Oral glucose } \\
\text { tolerance } \\
\text { test, fasting } \\
\text { plasma } \\
\text { glucose, } \\
\text { diabetes } \\
\text { drugs }\end{array}$ & $\begin{array}{l}\text { Oral glucose } \\
\text { tolerance } \\
\text { test, fasting } \\
\text { plasma } \\
\text { glucose, } \\
\text { diabetes } \\
\text { drugs }\end{array}$ \\
\hline $\begin{array}{l}\text { Cameron } 2008^{56} \\
\text { (both models } \\
\text { reported) }\end{array}$ & Australia & AusDiab & $\begin{array}{l}\text { Diabetes } \\
\text { prediction } \\
\text { model; and } \\
\text { Finnish diabetes } \\
\text { risk score }\end{array}$ & $\begin{array}{l}\text { Cohort } \\
\text { external } \\
\text { validation } \\
\text { study in } \\
\text { general } \\
\text { population }\end{array}$ & $\begin{array}{l}\text { Diabetes } \\
\text { incidence/prevalence } \\
\text { study }\end{array}$ & 11247 & 5,2000 & $\begin{array}{l}50.9 \\
(50.6-51.2)\end{array}$ & WHO criteria & WHO criteriô? \\
\hline
\end{tabular}


Table 1 (continued)

\begin{tabular}{|c|c|c|c|c|c|c|c|c|}
\hline Study* & Country & Name of study & $\begin{array}{c}\text { Name of risk } \\
\text { score }\end{array}$ & $\begin{array}{c}\text { Study design } \\
\text { and sampling } \\
\text { frame }\end{array}$ & $\begin{array}{l}\text { Why inception } \\
\text { cohort was } \\
\text { assembled }\end{array}$ & $\begin{array}{l}\text { Sample } \\
\text { size }\end{array}$ & $\begin{array}{c}\text { Duration: } \\
\text { mean (SD), } \\
\text { range (years), } \\
\text { or as reported }\end{array}$ & $\begin{array}{l}\text { Age: mean } \\
\text { (SD) or } \\
\text { range }\end{array}$ \\
\hline $\begin{array}{l}\text { Chen } 2010^{37} \text { (all } \\
\text { six models } \\
\text { reported) }\end{array}$ & Australia & Ausdiab & Ausdrisk & $\begin{array}{l}\text { Cohort } \\
\text { derivation } \\
\text { study in } \\
\text { general } \\
\text { population }\end{array}$ & $\begin{array}{l}\text { Diabetes } \\
\text { incidence/prevalence } \\
\text { study }\end{array}$ & 11247 & $5,1999-2005$ & $\geq 25$ \\
\hline
\end{tabular}

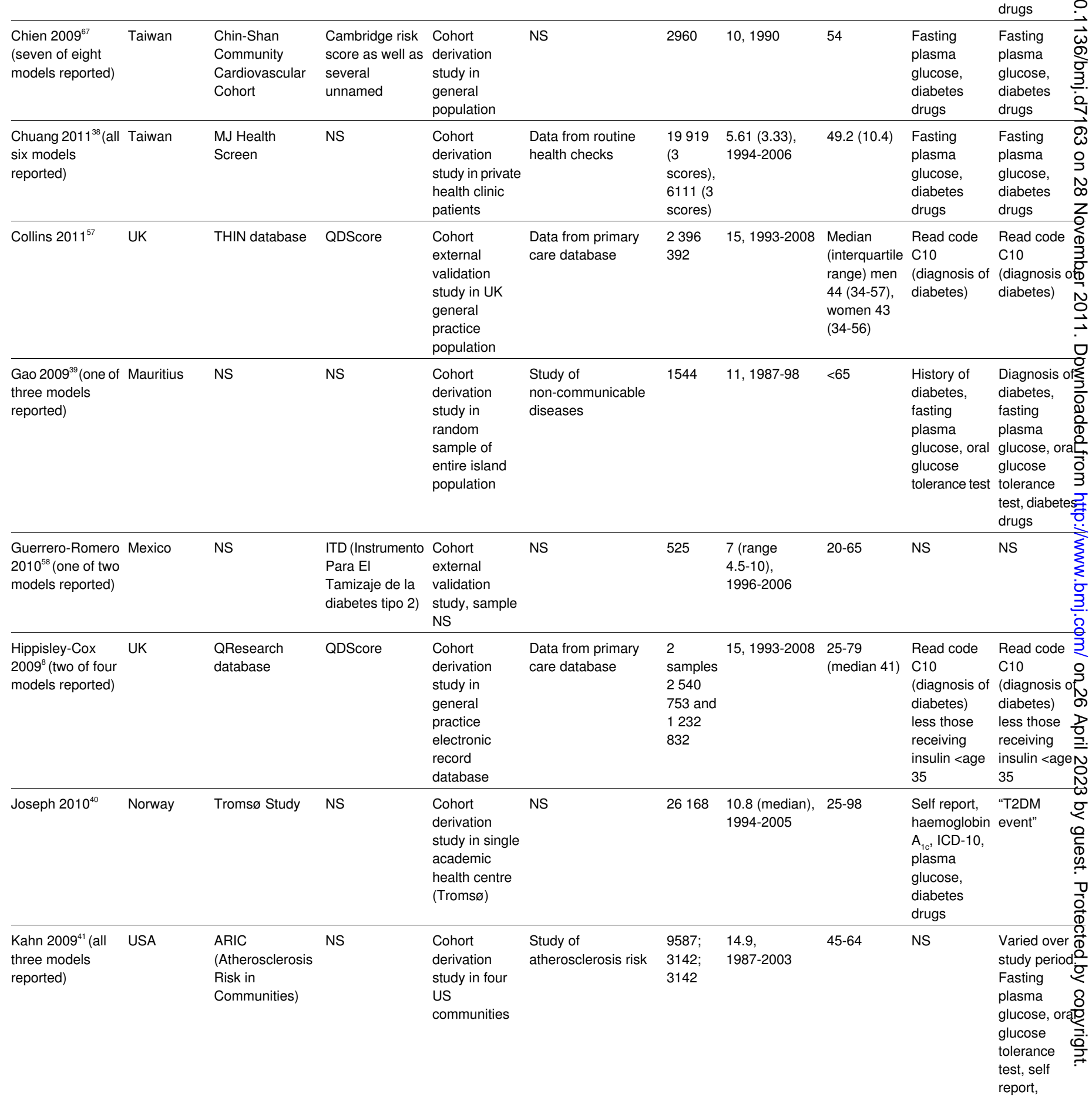


Table 1 (continued)

\begin{tabular}{|c|c|c|c|c|c|c|c|c|c|c|}
\hline Study ${ }^{*}$ & Country & Name of study & $\begin{array}{l}\text { Name of risk } \\
\text { score }\end{array}$ & $\begin{array}{l}\text { Study design } \\
\text { and sampling } \\
\text { frame }\end{array}$ & $\begin{array}{l}\text { Why inception } \\
\text { cohort was } \\
\text { assembled }\end{array}$ & $\begin{array}{l}\text { Sample } \\
\text { size }\end{array}$ & $\begin{array}{c}\text { Duration: } \\
\text { mean (SD), } \\
\text { range (years), } \\
\text { or as reported }\end{array}$ & $\begin{array}{l}\text { Age: mean } \\
\text { (SD) or } \\
\text { range }\end{array}$ & $\begin{array}{l}\text { How } \\
\text { diabetes } \\
\text { was } \\
\text { excluded at } \\
\text { inception }\end{array}$ & $\begin{array}{c}\text { How } \\
\text { incident } \frac{0}{2} \\
\text { diabetes? } \\
\text { was } \bar{\equiv} \\
\text { diagnosed }\end{array}$ \\
\hline & & & & & & & & & & $\begin{array}{l}\text { record, } \\
\text { survey }\end{array}$ \\
\hline Kanaya $2005^{59}$ & USA & $\begin{array}{l}\text { Health, Aging, } \\
\text { and Body } \\
\text { Composition } \\
\text { Study } \\
\text { (Validation) }\end{array}$ & NS & $\begin{array}{l}\text { Cohort } \\
\text { external } \\
\text { validation } \\
\text { study in two } \\
\text { clinics } \\
\text { (Memphis and } \\
\text { Pittsburgh) }\end{array}$ & NS & 2503 & $6,1997-2003$ & 70-79 & $\begin{array}{l}\text { Self report, } \\
\text { diabetes } \\
\text { drugs, fasting } \\
\text { plasma } \\
\text { glucose }\end{array}$ & $\begin{array}{l}\text { Fasting } \\
\text { plasma } \\
\text { glucose }\end{array}$ \\
\hline Kolberg $2009^{42}$ & USA & Inter99 & NS & $\begin{array}{l}\text { Cohort } \\
\text { derivation } \\
\text { study, sample } \\
\text { from Danish } \\
\text { civil register }\end{array}$ & $\begin{array}{l}\text { Lifestyle intervention } \\
\text { trial for cardiovascular } \\
\text { disease }\end{array}$ & 632 & $5, N S$ & $30-60$ & $\begin{array}{l}\text { Fasting } \\
\text { plasma } \\
\text { glucose, oral } \\
\text { glucose } \\
\text { tolerance test }\end{array}$ & $\begin{array}{l}\text { Fasting } \\
\text { plasma } \\
\text { glucose, ora } \\
\text { glucose } \\
\text { tolerance test }\end{array}$ \\
\hline $\begin{array}{l}\text { Lindstrom 2003 } \\
\text { (both models } \\
\text { reported) }\end{array}$ & Finland & FINRISK Studies & $\begin{array}{l}\text { Diabetes risk } \\
\text { score }\end{array}$ & $\begin{array}{l}\text { Cohort } \\
\text { derivation } \\
\text { study, national } \\
\text { population } \\
\text { register; and } \\
\text { cohort external } \\
\text { validation } \\
\text { study, } \\
\text { FINRISK }\end{array}$ & NS & $\begin{array}{l}4746 \\
4615\end{array}$ & $\begin{array}{l}\text { 10, 1987-97; } 5 \\
1992-7\end{array}$ & $45-64$ & $\begin{array}{l}\text { Fasting } \\
\text { plasma } \\
\text { glucose, oral } \\
\text { glucose } \\
\text { tolerance } \\
\text { test, diabetes } \\
\text { drugs }\end{array}$ & $\begin{array}{l}\text { Fasting } \\
\text { plasma } \\
\text { glucose, orak } \\
\text { glucose } \\
\text { tolerance } \\
\text { test, diabetes } \\
\text { drugs }\end{array}$ \\
\hline $\begin{array}{l}\text { Liu } 2011^{43} \text { (all } \\
\text { three models } \\
\text { reported) }\end{array}$ & China & NS & $\begin{array}{l}\text { Chinese } \\
\text { diabetes risk } \\
\text { score }\end{array}$ & $\begin{array}{l}\text { Cohort } \\
\text { derivation } \\
\text { study in } \\
\text { hospital } \\
\text { screening } \\
\text { centre for } \\
\text { military officers }\end{array}$ & $\begin{array}{l}\text { Analysis of routine } \\
\text { data from health } \\
\text { checks }\end{array}$ & 1457 & $10,1996-2006$ & $48-87$ & $\begin{array}{l}\text { Fasting } \\
\text { plasma } \\
\text { glucose, oral } \\
\text { glucose } \\
\text { tolerance test }\end{array}$ & $\begin{array}{l}\text { Self report, } \\
\text { fasting } \\
\text { plasma } \\
\text { glucose, oras } \\
\text { glucose } \\
\text { tolerance } \\
\text { test, diabetess } \\
\text { drugs }\end{array}$ \\
\hline Mainous $2007^{60}$ & USA & $\begin{array}{l}\text { Coronary Artery } \\
\text { Risk } \\
\text { Development in } \\
\text { Young Adults } \\
\text { (CARDIA) }\end{array}$ & NS & $\begin{array}{l}\text { Cohort } \\
\text { external } \\
\text { validation } \\
\text { study in young } \\
\text { adults } \\
\text { recruited to } \\
\text { CARDIA study }\end{array}$ & $\begin{array}{l}\text { Study of coronary } \\
\text { heart disease risk }\end{array}$ & 2543 & $10,1985-95$ & $18-30$ & $\begin{array}{l}\text { Self report, } \\
\text { fasting } \\
\text { plasma } \\
\text { glucose }\end{array}$ & $\begin{array}{l}\text { Self report, } \\
\text { fasting } \\
\text { plasma } \\
\text { glucose }\end{array}$ \\
\hline $\begin{array}{l}\text { Mann } 2010^{19} \text { (all } \\
\text { three models } \\
\text { reported) }\end{array}$ & USA & $\begin{array}{l}\text { Multi-ethnic } \\
\text { Study of } \\
\text { Atherosclerosis } \\
\text { (MESA) }\end{array}$ & NS & $\begin{array}{l}\text { Cohort } \\
\text { external } \\
\text { validation } \\
\text { study in adults } \\
\text { without } \\
\text { cardiovascular } \\
\text { disease in six } \\
\text { diverse US } \\
\text { communities }\end{array}$ & $\begin{array}{l}\text { Study of } \\
\text { atherosclerosis risk }\end{array}$ & 5329 & $4.75,2000-6$ & $61.6(45-84)$ & $\begin{array}{l}\text { Fasting } \\
\text { plasma } \\
\text { glucose, } \\
\text { diabetes } \\
\text { drugs }\end{array}$ & $\begin{array}{l}\text { Fasting } \\
\text { plasma } \\
\text { glucose, } \\
\text { diabetes } \\
\text { drugs }\end{array}$ \\
\hline $\begin{array}{l}\text { McNeely } 2003^{61} \\
\text { (one of two } \\
\text { models reported) }\end{array}$ & USA & $\begin{array}{l}\text { Japanese } \\
\text { American } \\
\text { Community } \\
\text { Diabetes Study }\end{array}$ & NS & $\begin{array}{l}\text { Cohort } \\
\text { external } \\
\text { validation } \\
\text { study, sample } \\
\text { NS }\end{array}$ & $\begin{array}{l}\text { Community diabetes } \\
\text { study }\end{array}$ & 518 & $5-10, N S$ & 52.1 (34-75) & $\begin{array}{l}\text { Fasting } \\
\text { plasma } \\
\text { glucose, oral } \\
\text { glucose } \\
\text { tolerance } \\
\text { test, diabetes } \\
\text { drugs }\end{array}$ & $\begin{array}{c}\text { Oral glucose } \\
\text { tolerance tes? }\end{array}$ \\
\hline $\begin{array}{l}\text { Mehrabi } 2010^{44} \\
\text { (one of four } \\
\text { models reported) }\end{array}$ & Iran & $\begin{array}{l}\text { Tehran Lipid and } \\
\text { Glucose Study }\end{array}$ & NS & $\begin{array}{l}\text { Cohort } \\
\text { derivation } \\
\text { study, sample } \\
\text { NS }\end{array}$ & $\begin{array}{l}\text { Study of lipid and } \\
\text { glucose risk factors }\end{array}$ & 5114 & 9, 1998-2007 & $\begin{array}{l}\text { Men } 43.4 \\
(14.1), \\
\text { women } 40.4 \\
(12.6)\end{array}$ & $\begin{array}{l}\text { Fasting } \\
\text { plasma } \\
\text { glucose, oral } \\
\text { glucose } \\
\text { tolerance } \\
\text { test, diabetes } \\
\text { drugs }\end{array}$ & NS \\
\hline
\end{tabular}


Table 1 (continued)

\begin{tabular}{|c|c|c|c|c|c|c|c|c|c|c|}
\hline Study* & Country & Name of study & $\begin{array}{c}\text { Name of risk } \\
\text { score }\end{array}$ & $\begin{array}{l}\text { Study design } \\
\text { and sampling } \\
\text { frame }\end{array}$ & $\begin{array}{l}\text { Why inception } \\
\text { cohort was } \\
\text { assembled }\end{array}$ & $\begin{array}{l}\text { Sample } \\
\text { size }\end{array}$ & $\begin{array}{c}\text { Duration: } \\
\text { mean (SD), } \\
\text { range (years), } \\
\text { or as reported }\end{array}$ & $\begin{array}{l}\text { Age: mean } \\
\text { (SD) or } \\
\text { range }\end{array}$ & $\begin{array}{c}\text { How } \\
\text { diabetes } \\
\text { was } \\
\text { excluded at } \\
\text { inception }\end{array}$ & $\begin{array}{c}\text { How } \\
\text { incident } \\
\text { diabetes } \\
\text { was } \\
\text { diagnosed }\end{array}$ \\
\hline Meigs $2008^{9}$ & USA & $\begin{array}{l}\text { Framingham } \\
\text { Offspring Study }\end{array}$ & Genotype score & $\begin{array}{l}\text { Cohort } \\
\text { external } \\
\text { validation } \\
\text { study, sample } \\
\text { NS }\end{array}$ & $\begin{array}{l}\text { Study of children of } \\
\text { Framingham Heart } \\
\text { Study participants }\end{array}$ & 2377 & $28,1971-2001$ & $28-62$ & $\begin{array}{l}\text { Fasting } \\
\text { plasma } \\
\text { glucose, } \\
\text { diabetes } \\
\text { drugs }\end{array}$ & 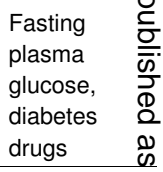 \\
\hline $\begin{array}{l}\text { Nichols } 2008^{62} \text { (all } \\
\text { three models } \\
\text { reported) }\end{array}$ & USA & $\begin{array}{l}\text { Kaiser } \\
\text { Permanente } \\
\text { Northwest } \\
\text { electronic } \\
\text { records }\end{array}$ & $\begin{array}{l}\text { Framingham } \\
\text { Offspring Study } \\
\text { score }\end{array}$ & $\begin{array}{l}\text { Cohort } \\
\text { external } \\
\text { validation } \\
\text { study in health } \\
\text { maintenance } \\
\text { organisation } \\
\text { registered } \\
\text { population }\end{array}$ & $\begin{array}{l}\text { Analysis of health } \\
\text { maintenance } \\
\text { organisation } \\
\text { electronic records }\end{array}$ & 20,644 & 7, 1999-2007 & 57.4 & NS & $\begin{array}{l}\text { Diagnosis of } \\
\text { diabetes } \\
\text { (ICD-9 } \\
\text { codes), } \\
\text { fasting } \\
\text { plasma } \\
\text { glucose, } \\
\text { diabetes } \\
\text { drugs }\end{array}$ \\
\hline Rahman $2008^{63}$ & UK & $\begin{array}{l}\text { European } \\
\text { Prospective } \\
\text { Investigation of } \\
\text { Cancer } \\
\text { (EPIC)-Norfolk }\end{array}$ & $\begin{array}{l}\text { Cambridge risk } \\
\text { score }\end{array}$ & $\begin{array}{l}\text { Cohort } \\
\text { external } \\
\text { validation } \\
\text { study in UK } \\
\text { general } \\
\text { practice }\end{array}$ & $\begin{array}{l}\text { Study of causes of } \\
\text { cancer }\end{array}$ & 24,495 & $\begin{array}{l}4.8(1.3) \\
1993-2000\end{array}$ & $58.9(40-79)$ & $\begin{array}{l}\text { Self report, } \\
\text { diabetes } \\
\text { drugs, clinic } \\
\text { registers, } \\
\text { death } \\
\text { certificates }\end{array}$ & As inception \\
\hline $\begin{array}{l}\text { Rathmann } 2010^{85} \\
\text { (all three models } \\
\text { reported) }\end{array}$ & Germany & $\begin{array}{l}\text { KORA S4/F4 } \\
\text { study }\end{array}$ & NS & $\begin{array}{l}\text { Cohort } \\
\text { derivation } \\
\text { study, sample } \\
\text { NS }\end{array}$ & NS & 1202 & $\begin{array}{l}\text { Implicitly, 7, } \\
\text { 1999-2008 }\end{array}$ & $55-74$ & $\begin{array}{l}\text { Oral glucose } \\
\text { tolerance test }\end{array}$ & $\begin{array}{l}\text { Diagnosis of } \\
\text { diabetes, oraP } \\
\text { glucose } \\
\text { tolerance tes }\end{array}$ \\
\hline $\begin{array}{l}\text { Rosella } 2010^{69} \text { (all } \\
\text { three models } \\
\text { reported) }\end{array}$ & Canada & $\begin{array}{l}\text { National } \\
\text { Population } \\
\text { Health } \\
\text { Survey-Ontario }\end{array}$ & $\begin{array}{l}\text { Dport (Diabetes } \\
\text { population at } \\
\text { risk tool) }\end{array}$ & $\begin{array}{l}\text { Cohort } \\
\text { derivation } \\
\text { study, sample } \\
\text { NS }\end{array}$ & Health survey & $\begin{array}{l}19795 ; \\
9899 ; 26 \\
465\end{array}$ & $\begin{array}{l}9,1996-7 ; 9 \\
1996-2005 ; 5, \\
2000-5\end{array}$ & $\begin{array}{l}\text { Men } 44 \text {, } \\
\text { women } 46 \text {; } \\
\text { men } 44 \text {, } \\
\text { women } 47 \text {; } \\
\text { men } 44 \text {, } \\
\text { women } 46\end{array}$ & NS & 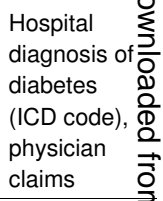 \\
\hline $\begin{array}{l}\text { Schmidt } 2005^{46} \\
\text { (all three models } \\
\text { reported) }\end{array}$ & USA & $\begin{array}{l}\text { ARIC } \\
\text { (Atherosclerosis } \\
\text { Risk in } \\
\text { Communities) }\end{array}$ & NS & $\begin{array}{l}\text { Cohort } \\
\text { derivation } \\
\text { study in four } \\
\text { US } \\
\text { communities }\end{array}$ & $\begin{array}{l}\text { Study of } \\
\text { atherosclerosis risk }\end{array}$ & 7915 & $9,1987-98$ & $\begin{array}{l}\text { Median } 54 \\
(45-64)\end{array}$ & $\begin{array}{l}\text { Diagnosis of } \\
\text { diabetes } \\
\text { (including } \\
\text { self report), } \\
\text { fasting } \\
\text { plasma } \\
\text { glucose, } \\
\text { diabetes } \\
\text { drugs }\end{array}$ & $\begin{array}{l}\text { Diagnosis of } \\
\text { diabetes, } \\
\text { fasting } \\
\text { plasma } \\
\text { glucose, or } \\
\text { glucose } \\
\text { tolerance } \\
\text { test, diabetes } \\
\text { drugs }\end{array}$ \\
\hline $\begin{array}{l}\text { Schulze } 2007^{70} \\
\text { (both models } \\
\text { reported) }\end{array}$ & Germany & $\begin{array}{l}\text { EPIC-Potsdam; } \\
\text { and } \\
\text { EPIC-Heidelberg }\end{array}$ & $\begin{array}{l}\text { German } \\
\text { diabetes risk } \\
\text { score }\end{array}$ & $\begin{array}{l}\text { Cohort } \\
\text { derivation } \\
\text { study } \\
\text { (Potsdam); } \\
\text { cohort external } \\
\text { validation } \\
\text { study } \\
\text { (Heidelberg) }\end{array}$ & $\begin{array}{l}\text { Study of causes of } \\
\text { cancer }\end{array}$ & $\begin{array}{l}27548 \\
25540\end{array}$ & $7, \mathrm{NS} ; 5, \mathrm{NS}$ & $\begin{array}{l}\text { Men } 40-65 \text {, } \\
\text { women } \\
35-65 ; \text { NS }\end{array}$ & NS & 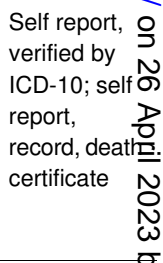 \\
\hline Schulze $2009^{47}$ & Germany & EPIC-Potsdam & $\begin{array}{l}\text { Adaptation of } \\
\text { German } \\
\text { diabetes risk } \\
\text { score }\end{array}$ & $\begin{array}{l}\text { Cohort } \\
\text { derivation } \\
\text { study in } \\
\text { general } \\
\text { population } \\
\text { (Potsdam) }\end{array}$ & $\begin{array}{l}\text { Study of causes of } \\
\text { cancer }\end{array}$ & 1962 & $7.1,1994$ & $35-65$ & $\begin{array}{l}\text { Self report } \\
\text { verified by } \\
\text { physician }\end{array}$ & 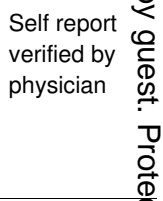 \\
\hline $\begin{array}{l}\text { Simmons } 2007^{71} \\
\text { (both models } \\
\text { reported) }\end{array}$ & UK & EPIC-Norfolk & $\begin{array}{l}\text { NS; Cambridge } \\
\text { risk score }\end{array}$ & $\begin{array}{l}\text { Cohort } \\
\text { derivation } \\
\text { study; cohort } \\
\text { external } \\
\text { validation } \\
\text { study, sample } \\
\text { NS }\end{array}$ & $\begin{array}{l}\text { Study of causes of } \\
\text { cancer }\end{array}$ & 12591 & $4.6,1993-2000$ & $40-79$ & Self report & 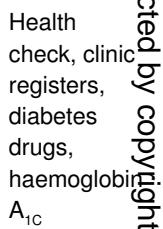 \\
\hline
\end{tabular}


Table 1 (continued)

\begin{tabular}{|c|c|c|c|c|c|c|c|c|}
\hline Study ${ }^{*}$ & Country & Name of study & $\begin{array}{c}\text { Name of risk } \\
\text { score }\end{array}$ & $\begin{array}{c}\text { Study design } \\
\text { and sampling } \\
\text { frame }\end{array}$ & $\begin{array}{l}\text { Why inception } \\
\text { cohort was } \\
\text { assembled }\end{array}$ & $\begin{array}{l}\text { Sample } \\
\text { size }\end{array}$ & $\begin{array}{c}\text { Duration: } \\
\text { mean (SD), } \\
\text { range (years), } \\
\text { or as reported }\end{array}$ & $\begin{array}{l}\text { Age: mean } \\
\text { (SD) or } \\
\text { range }\end{array}$ \\
\hline $\begin{array}{l}\text { Stern } 1993^{48} \text { (two } \\
\text { of six models } \\
\text { reported) }\end{array}$ & USA & $\begin{array}{l}\text { San Antonio } \\
\text { Heart Study }\end{array}$ & NS & $\begin{array}{l}\text { Cohort } \\
\text { derivation } \\
\text { study, sample } \\
\text { NS }\end{array}$ & $\begin{array}{l}\text { Population based } \\
\text { study of diabetes and } \\
\text { cardiovascular } \\
\text { disease }\end{array}$ & 2217 & $8,1979-87$ & $25-64$ \\
\hline
\end{tabular}

\begin{tabular}{|c|c|c|c|c|c|c|c|}
\hline $\begin{array}{l}\text { Stern } 2002^{86} \text { (both USA } \\
\text { models reported) }\end{array}$ & $\begin{array}{l}\text { San Antonio } \\
\text { Heart Study }\end{array}$ & NS & $\begin{array}{l}\text { Cohort } \\
\text { derivation } \\
\text { study, sample } \\
\text { NS }\end{array}$ & $\begin{array}{l}\text { Population based } \\
\text { study of diabetes and } \\
\text { cardiovascular } \\
\text { disease }\end{array}$ & 5158 & $7-8,1979-88$ & 25-64 \\
\hline
\end{tabular}

\begin{tabular}{|c|c|c|c|c|c|c|c|c|c|c|}
\hline & & & & & & & & & drugs & drugs \\
\hline $\begin{array}{l}\text { Sun } 2009^{72} \text { (three } \\
\text { of six models } \\
\text { reported) }\end{array}$ & Taiwan & $\begin{array}{l}\text { Taiwan } \\
\text { health-check-up } \\
\text { database } \\
\text { (MJLPD) }\end{array}$ & $\begin{array}{l}\text { Atherosclerosis } \\
\text { Risk in } \\
\text { Communities } \\
\text { (ARIC) score }\end{array}$ & $\begin{array}{l}\text { Cohort } \\
\text { derivation } \\
\text { study in private } \\
\text { patient sample }\end{array}$ & NS & 10294 & $\begin{array}{l}\text { Median 3.15, } \\
\text { 1997-2006 }\end{array}$ & $47.5(35-74)$ & $\begin{array}{l}\text { Fasting } \\
\text { plasma } \\
\text { glucose, } \\
\text { diabetes } \\
\text { drugs }\end{array}$ & NS \\
\hline $\begin{array}{l}\text { Talmud } 2010^{10} \\
\text { (two of three } \\
\text { models reported) }\end{array}$ & UK & Whitehall II & $\begin{array}{l}\text { Cambridge Risk } \\
\text { Score; and } \\
\text { Framingham } \\
\text { Offspring Study } \\
\text { score }\end{array}$ & $\begin{array}{l}\text { Cohort } \\
\text { external } \\
\text { validation } \\
\text { study in civil } \\
\text { servant } \\
\text { sample }\end{array}$ & $\begin{array}{l}\text { Study of health in civil } \\
\text { servants }\end{array}$ & 8713 & $\begin{array}{l}11.7 \text { (median), } \\
\text { NS }\end{array}$ & $49(35-55)$ & $\begin{array}{l}\text { Oral glucose } \\
\text { tolerance test }\end{array}$ & $\begin{array}{l}\text { Oral glucose } \\
\text { tolerance } \\
\text { test, diabete } \\
\text { drugs, self } \\
\text { report of } \\
\text { doctor } \\
\text { diagnosis }\end{array}$ \\
\hline $\begin{array}{l}\text { Urdea } 2009^{64} \text { (one } \\
\text { score, two studies, } \\
\text { both reported) }\end{array}$ & Denmark & Inter99 & $\begin{array}{l}\text { PreDx diabetes } \\
\text { risk score } \\
\text { training set; } \\
\text { PreDx diabetes } \\
\text { risk score } \\
\text { validation set }\end{array}$ & $\begin{array}{l}\text { Cohort } \\
\text { external } \\
\text { validation } \\
\text { study, sample } \\
\text { not stated }\end{array}$ & $\begin{array}{l}\text { Primary prevention } \\
\text { study of } \\
\text { cardiovascular } \\
\text { disease }\end{array}$ & $399 ; 400$ & $5, \mathrm{NS}$ & $40-55$ & NS & NS \\
\hline $\begin{array}{l}\text { Von Eckardstein } \\
2000^{50}\end{array}$ & Germany & $\begin{array}{l}\text { PROCAM } \\
\text { (Prospective } \\
\text { Cardiovascular } \\
\text { Münster Study) }\end{array}$ & $\begin{array}{l}\text { Multiple logistic } \\
\text { function model }\end{array}$ & $\begin{array}{l}\text { Cohort } \\
\text { derivation } \\
\text { study in } \\
\text { employees of } \\
52 \text { companies } \\
\text { and authorities } \\
\text { in Münster }\end{array}$ & $\begin{array}{l}\text { To examine } \\
\text { cardiovascular risk } \\
\text { factors, events, and } \\
\text { mortality }\end{array}$ & 3737 & $4-10,1979-95$ & $30-60$ & $\begin{array}{l}\text { Self report, } \\
\text { fasting } \\
\text { plasma } \\
\text { glucose, } \\
\text { diabetes } \\
\text { drugs }\end{array}$ & $\begin{array}{l}\text { Self report, } \\
\text { diabetes } \\
\text { drugs, fastin } \\
\text { plasma } \\
\text { glucose }\end{array}$ \\
\hline $\begin{array}{l}\text { Wannamethee } \\
2011^{27} \text { (all three } \\
\text { models reported) }\end{array}$ & UK & $\begin{array}{l}\text { British Regional } \\
\text { Heart Study and } \\
\text { British Women's } \\
\text { Heart and Health } \\
\text { Study }\end{array}$ & NS & $\begin{array}{l}\text { Cohort } \\
\text { derivation } \\
\text { study, sample } \\
\text { not stated }\end{array}$ & $\begin{array}{l}\text { Study of } \\
\text { cardiovascular risk }\end{array}$ & 6927 & 7, 1998-2007 & $60-79$ & $\begin{array}{l}\text { Doctor } \\
\text { diagnosis of } \\
\text { diabetes, } \\
\text { fasting } \\
\text { plasma } \\
\text { glucose }\end{array}$ & $\begin{array}{l}\text { Record } \\
\text { review, self } \\
\text { report }\end{array}$ \\
\hline $\begin{array}{l}\text { Wannamethee } \\
2005^{65}\end{array}$ & UK & $\begin{array}{l}\text { British Regional } \\
\text { Heart Study }\end{array}$ & $\begin{array}{l}\text { Framingham risk } \\
\text { score }\end{array}$ & $\begin{array}{l}\text { Cohort } \\
\text { external } \\
\text { validation } \\
\text { study in } \\
\text { sample of } \\
\text { mostly manual } \\
\text { social class }\end{array}$ & Heart study & 5128 & $\begin{array}{l}21.3 \\
1978-2000\end{array}$ & $\begin{array}{l}50.3(5.7) \\
40-59\end{array}$ & $\begin{array}{l}\text { Recall of } \\
\text { doctor } \\
\text { diagnosis, } \\
\text { high blood } \\
\text { glucose }\end{array}$ & NS \\
\hline $\begin{array}{l}\text { Wilson } 2007^{51} \\
\text { (one of seven } \\
\text { models reported) }\end{array}$ & USA & $\begin{array}{l}\text { Framingham } \\
\text { Offspring Study }\end{array}$ & NS & $\begin{array}{l}\text { Cohort } \\
\text { derivation } \\
\text { study, sample } \\
\text { not stated }\end{array}$ & $\begin{array}{l}\text { Population based } \\
\text { study of health } \\
\text { outcomes }\end{array}$ & 3140 & $\begin{array}{l}\text { 7, } \\
\text { mid-1990-2001 }\end{array}$ & 54 & $\begin{array}{l}\text { History of } \\
\text { diabetes, oral } \\
\text { glucose } \\
\text { tolerance } \\
\text { test, fasting } \\
\text { plasma } \\
\text { glucose, } \\
\text { diabetes } \\
\text { drugs }\end{array}$ & $\begin{array}{l}\text { Fasting } \\
\text { plasma } \\
\text { glucose, } \\
\text { diabetes } \\
\text { drugs }\end{array}$ \\
\hline
\end{tabular}

NS=not stated; WHO=World Health Organization; ICD-10=International Classification of Disease, 10 th revision; ICD-9=International Classification of Diseases, ninth revision. 
Table 1 (continued)

Country
Study




\begin{tabular}{|c|c|c|c|c|c|c|c|}
\hline Study & $\begin{array}{l}\text { Diabetes } \\
\text { incidence } \\
(\%)^{\star}\end{array}$ & Components of score & $\begin{array}{c}\text { Sensitivity/specificity } \dagger \\
\%\end{array}$ & $\begin{array}{l}\text { AUROC } \\
(95 \% \mathrm{CI})\end{array}$ & $\begin{array}{l}\text { Positive/negative } \\
\text { predictive value } \\
\text { (\%) }\end{array}$ & Calibration & $\begin{array}{c}\% \\
\text { needing } \\
\text { further } \\
\text { tests }\end{array}$ \\
\hline Aekplakorn $2006^{7}$ & 11.1 & $\begin{array}{l}\text { Age, BMI, waist circumference, } \\
\text { hypertension, family history of } \\
\text { diabetes in first degree relative }\end{array}$ & $77 / 60$ & $\begin{array}{l}0.74(0.71 \text { to } \\
0.78)\end{array}$ & NS/NS & $\begin{array}{l}\text { Hosmer-Lemeshow } \\
P=0.8\end{array}$ & NS \\
\hline Aekplakorn $2006^{7}$ & 5.2 & $\begin{array}{l}\text { Age, BMI, waist circumference, } \\
\text { hypertension, family history of } \\
\text { diabetes in first degree relative }\end{array}$ & $84.4 / 52.5$ & $\begin{array}{l}0.75(0.71 \text { to } \\
0.80)\end{array}$ & NS/NS & NS & NS \\
\hline Alssema $2008^{52}$ & $\begin{array}{l}22.3 \text { per } \\
1000 \\
\text { person } \\
\text { years }\end{array}$ & $\begin{array}{l}\text { Age, BMI, waist circumference, use } \\
\text { of antihypertensive drugs, parental } \\
\text { history of diabetes, family history of } \\
\text { diabetes in first degree relative }\end{array}$ & $\begin{array}{l}84 / 42 \text { (cut-off } \geq 7 \text { ); } 52 / 76 \\
\text { (cut-off } \geq 10 \text { ) }\end{array}$ & $\begin{array}{l}0.71(0.68 \text { to } \\
0.75)\end{array}$ & $\begin{array}{l}19 / 94 \text { (cut-off } \geq 7 \text { ); } \\
26 / 91 \text { (cut-off } \geq 10 \text { ) }\end{array}$ & NS & 28 \\
\hline Alssema $2008^{52}$ & $\begin{array}{l}10.7 \text { per } \\
1000 \\
\text { person } \\
\text { years }\end{array}$ & $\begin{array}{l}\text { Age, BMI, waist circumference, use } \\
\text { of antihypertensive drugs, parental } \\
\text { history of diabetes, family history of } \\
\text { diabetes in first degree relative }\end{array}$ & $\begin{array}{l}78 / 64 \text { (cut-off } \geq 7 \text { ); } 43 / 85 \\
\text { (cut-off } \geq 10 \text { ) }\end{array}$ & $\begin{array}{l}0.77(0.73 \text { to } \\
0.80)\end{array}$ & $\begin{array}{l}9 / 98 \text { (cut-off } \geq 7 \text { ) } \\
12 / 97 \text { (cut-off } \geq 10 \text { ) }\end{array}$ & NS & 16 \\
\hline Alssema $2011^{53}$ & $\begin{array}{l}\text { Range } \\
2.3-9.9 \\
\text { across five } \\
\text { substudies }\end{array}$ & $\begin{array}{l}\text { Age, BMI, waist circumference, use } \\
\text { of antihypertensive drugs, history of } \\
\text { gestational diabetes }\end{array}$ & NS/NS & $\begin{array}{l}0.77(0.75 \text { to } \\
0.78)\end{array}$ & NS/NS & NS & NS \\
\hline Alssema $2011^{53}$ & $\begin{array}{l}\text { Range } \\
2.3-9.9 \\
\text { across five } \\
\text { substudies }\end{array}$ & $\begin{array}{l}\text { Age, BMI, waist circumference, use } \\
\text { of antihypertensive drugs, history of } \\
\text { gestational diabetes, sex, smoking, } \\
\text { family history of diabetes }\end{array}$ & $76 / 63$ & $\begin{array}{l}0.76(0.75 \text { to } \\
0.78)\end{array}$ & $11 / \mathrm{NS}$ & $\begin{array}{l}\text { Hosmer-Lemeshow } \\
P=0.27\end{array}$ & 40 \\
\hline Balkau $2008^{36}$ & 7.5 & $\begin{array}{l}\text { Waist circumference, smoking, } \\
\text { hypertension }\end{array}$ & NS/NS & 0.71 (NS) & NS/NS & $\begin{array}{l}\text { Hosmer-Lemeshow } \\
\mathrm{P}=0.8\end{array}$ & NS \\
\hline Balkau $2008^{36}$ & 3.2 & $\begin{array}{l}\text { Waist circumference, family history } \\
\text { of diabetes, hypertension }\end{array}$ & NS/NS & 0.83 & NS/NS & $\begin{array}{l}\text { Hosmer-Lemeshow } \\
\mathrm{P}=0.9\end{array}$ & NS \\
\hline $\begin{array}{l}\text { Bozorgmanesh } \\
2011^{54}\end{array}$ & 4.6 & $\begin{array}{l}\text { Age, family history of diabetes, } \\
\text { hypertension, waist circumference, } \\
\text { fasting plasma glucose level, height, } \\
\text { pulse, triglyceride-high density } \\
\text { lipoprotein ratio }\end{array}$ & $\begin{array}{l}\text { Men } 71.6 / 75.3 \text {, women } \\
67.1 / 85.0\end{array}$ & $\begin{array}{l}\text { Men } 0.79, \\
\text { women } 0.829\end{array}$ & NS/NS & $\begin{array}{l}\text { Hosmer-Lemeshow } \\
P=0.129\end{array}$ & NS \\
\hline $\begin{array}{l}\text { Bozorgmanesh } \\
2011^{66}\end{array}$ & 4.6 & $\begin{array}{l}\text { Age, family history of diabetes, } \\
\text { systolic blood pressure, waist-hip } \\
\text { ratio, waist-height ratio }\end{array}$ & NS/NS & $\begin{array}{l}0.75(0.72 \text { to } \\
0.78)\end{array}$ & NS/NS & NS & NS \\
\hline $\begin{array}{l}\text { Bozorgmanesh } \\
2011^{66}\end{array}$ & 4.6 & $\begin{array}{l}\text { Family history of diabetes, systolic } \\
\text { blood pressure, waist-height ratio, } \\
\text { triglyceride-high density lipoprotein } \\
\text { ratio, fasting plasma glucose level }\end{array}$ & NS/NS & $\begin{array}{l}0.85(0.82 \text { to } \\
0.87)\end{array}$ & NS/NS & NS & NS \\
\hline $\begin{array}{l}\text { Bozorgmanesh } \\
2011^{66}\end{array}$ & 4.6 & $\begin{array}{l}\text { Family history of diabetes, systolic } \\
\text { blood pressure, waist-height ratio, } \\
\text { triglyceride-high density lipoprotein } \\
\text { ratio, fasting plasma glucose level, } \\
\text { two hour postprandial plasma glucose } \\
\text { level }\end{array}$ & NS/NS & $\begin{array}{l}0.86(0.83 \text { to } \\
0.89)\end{array}$ & NS/NS & NS & NS \\
\hline $\begin{array}{l}\text { Bozorgmanesh } \\
2011^{66}\end{array}$ & 4.6 & $\begin{array}{l}\text { Systolic blood pressure, waist-height } \\
\text { ratio, fasting plasma glucose level, } \\
\text { triglyceride-high density lipoprotein } \\
\text { ratio, family history of diabetes }\end{array}$ & $75 / 77$ & $\begin{array}{l}0.83(0.80 \text { to } \\
0.86)\end{array}$ & NS/NS & $\begin{array}{l}\text { Hosmer-Lemeshow } \\
P=0.631\end{array}$ & NS \\
\hline $\begin{array}{l}\text { Bozorgmanesh } \\
2011^{66}\end{array}$ & 4.6 & NS & NS/NS & $\begin{array}{l}0.78(0.75 \text { to } \\
0.81)\end{array}$ & NS/NS & $\begin{array}{l}\text { Hosmer-Lemeshow } \\
P=0.264\end{array}$ & NS \\
\hline $\begin{array}{l}\text { Bozorgmanesh } \\
2010^{55}\end{array}$ & 4.6 & $\begin{array}{l}\text { "San Antonio diabetes prediction } \\
\text { model" }\end{array}$ & NS/NS & $\begin{array}{l}0.83(0.80 \text { to } \\
0.86)\end{array}$ & NS/NS & $\begin{array}{l}\text { Hosmer-Lemeshow } \\
P<0.001 \text {, when } \\
\text { recalibrated } \\
P=0.131\end{array}$ & NS \\
\hline Cameron $2008^{56}$ & 2.0 & $\begin{array}{l}\text { Age, sex, ethnicity, fasting plasma } \\
\text { glucose level, systolic blood pressure, } \\
\text { high density lipoprotein cholesterol } \\
\text { level, BMI, family history of diabetes }\end{array}$ & $62.4 / 82.3$ & NS & $11.9 / 98.3$ & NS & 19.3 \\
\hline Cameron $2008^{56}$ & 2.0 & NS & $62.3 / 70.5$ & NS & $6.8 / 98.2$ & NS & 30.6 \\
\hline
\end{tabular}


Table 2 (continued)

\begin{tabular}{|c|c|c|c|c|c|c|c|}
\hline Study & $\begin{array}{c}\text { Diabetes } \\
\text { incidence } \\
(\%)^{\star}\end{array}$ & Components of score & $\begin{array}{c}\text { Sensitivity/specificity } \dagger \\
\%\end{array}$ & $\begin{array}{l}\text { AUROC } \\
(95 \% \mathrm{Cl})\end{array}$ & $\begin{array}{l}\text { Positive/negative } \\
\text { predictive value } \\
\text { (\%) }\end{array}$ & Calibration & $\begin{array}{c}\% \\
\text { needing } \\
\text { further } \\
\text { tests }\end{array}$ \\
\hline Chen $2010^{37}$ & 3.2 & $\begin{array}{l}\text { Age, sex, ethnicity, parental history } \\
\text { of diabetes, history of high blood } \\
\text { glucose levels, use of } \\
\text { antihypertensive drugs, lipid lowering } \\
\text { drugs, smoking, physical inactivity, } \\
\text { waist circumference, BMI, education, } \\
\text { occupation }\end{array}$ & NS/NS & $\begin{array}{l}0.79(0.76 \text { to } \\
0.81)\end{array}$ & NS/NS & $\begin{array}{l}\text { Hosmer-Lemeshow } \\
P=0.06\end{array}$ & NS \\
\hline Chen $2010^{37}$ & 3.2 & $\begin{array}{l}\text { Age, sex, ethnicity, parental history } \\
\text { of diabetes, history of high blood } \\
\text { glucose levels, use of } \\
\text { antihypertensive drugs, lipid lowering } \\
\text { drugs, smoking, physical inactivity, } \\
\text { waist circumference, BMI, education }\end{array}$ & NS/NS & $\begin{array}{l}0.79(0.76 \text { to } \\
0.81)\end{array}$ & NS/NS & $\begin{array}{l}\text { Hosmer-Lemeshow } \\
P=0.02\end{array}$ & NS \\
\hline Chen $2010^{37}$ & 3.2 & $\begin{array}{l}\text { Age, sex, ethnicity, parental history } \\
\text { of diabetes, history of high blood } \\
\text { glucose levels, use of } \\
\text { antihypertensive drugs, lipid lowering } \\
\text { drugs, smoking, physical inactivity, } \\
\text { waist circumference, BMI }\end{array}$ & NS/NS & $\begin{array}{l}0.79(0.76 \text { to } \\
0.81)\end{array}$ & NS/NS & $\begin{array}{l}\text { Hosmer-Lemeshow } \\
P=0.06\end{array}$ & NS \\
\hline Chen $2010^{37}$ & 3.2 & $\begin{array}{l}\text { Age, sex, ethnicity, parental history } \\
\text { of diabetes, history of high blood } \\
\text { glucose levels, antihypertensive } \\
\text { drugs, smoking, physical inactivity, } \\
\text { waist circumference, BMI }\end{array}$ & NS/NS & $\begin{array}{l}0.79(0.76 \text { to } \\
0.81)\end{array}$ & NS/NS & $\begin{array}{l}\text { Hosmer-Lemeshow } \\
P=0.02\end{array}$ & NS \\
\hline Chen $2010^{37}$ & 3.2 & $\begin{array}{l}\text { Age, sex, ethnicity, parental history } \\
\text { of diabetes, history of high blood } \\
\text { glucose levels, use of } \\
\text { antihypertensive drugs, smoking, } \\
\text { physical inactivity, waist } \\
\text { circumference }\end{array}$ & NS/NS & $\begin{array}{l}0.78(0.76 \text { to } \\
0.81)\end{array}$ & NS/NS & $\begin{array}{l}\text { Hosmer-Lemeshow } \\
\mathrm{P}=0.85\end{array}$ & NS \\
\hline Chen $2010^{37}$ & 3.2 & $\begin{array}{l}\text { Age, sex, ethnicity, parental history } \\
\text { of diabetes, history of high blood } \\
\text { glucose levels, use of } \\
\text { antihypertensive drugs, smoking, } \\
\text { physical inactivity, BMI }\end{array}$ & NS/NS & $\begin{array}{l}0.78(0.75 \text { to } \\
0.80)\end{array}$ & NS/NS & $\begin{array}{l}\text { Hosmer-Lemeshow } \\
P=0.66\end{array}$ & NS \\
\hline Chien $2009^{67}$ & 18.5 & $\begin{array}{l}\text { Age, BMI, white blood cell count, } \\
\text { triglyceride level, high density } \\
\text { lipoprotein cholesterol level, fasting } \\
\text { plasma glucose level }\end{array}$ & $52 / 78$ & $\begin{array}{l}0.70(0.68 \text { to } \\
0.73)\end{array}$ & NS/NS & $\begin{array}{l}\text { Hosmer-Lemeshow } \\
P=0.874\end{array}$ & NS \\
\hline Chien $2009^{67}$ & 18.5 & $\begin{array}{l}\text { Age, BMI, white blood cell count, } \\
\text { triglyceride level, high density } \\
\text { lipoprotein cholesterol level, fasting } \\
\text { plasma glucose level, family history } \\
\text { of diabetes, systolic blood pressure }\end{array}$ & $69 / 62$ & $\begin{array}{l}0.70(0.68 \text { to } \\
0.73)\end{array}$ & NS/NS & NS & NS \\
\hline Chien $2009^{67}$ & 18.5 & $\begin{array}{l}\text { Age, sex, BMI, family history of } \\
\text { diabetes, use of antihypertensive } \\
\text { drugs }\end{array}$ & NS/NS & $\begin{array}{l}0.65(0.62 \text { to } \\
0.67)\end{array}$ & NS/NS & NS & NS \\
\hline Chien $2009^{67}$ & 18.5 & NS & $66 / 56$ & NS & NS/NS & $\begin{array}{l}\text { Hosmer-Lemeshow } \\
\mathrm{P}=0.008\end{array}$ & NS \\
\hline Chien $2009^{67}$ & 18.5 & NS & $72 / 40$ & NS & NS/NS & $\begin{array}{l}\text { Hosmer-Lemeshow } \\
P=0.001\end{array}$ & NS \\
\hline Chien $2009^{67}$ & 18.5 & NS & $55 / 72$ & NS & NS/NS & $\begin{array}{l}\text { Hosmer-Lemeshow } \\
\mathrm{P}=0.002\end{array}$ & NS \\
\hline Chien $2009^{67}$ & 18.5 & NS & $48 / 78$ & NS & NS/NS & $\begin{array}{l}\text { Hosmer-Lemeshow } \\
P=0.032\end{array}$ & NS \\
\hline Chuang $2011^{38}$ & 6.4 & $\begin{array}{l}\text { Age, sex, education, alcohol, BMI, } \\
\text { waist circumference }\end{array}$ & NS/NS & $\begin{array}{l}0.71(0.70 \text { to } \\
0.73)\end{array}$ & NS/NS & NS & NS \\
\hline Chuang $2011^{38}$ & 6.4 & $\begin{array}{l}\text { Age, sex, education, alcohol, BMI, } \\
\text { waist circumference, blood pressure, } \\
\text { hypertension }\end{array}$ & NS/NS & $\begin{array}{l}0.720(0.71 \\
\text { to } 0.74)\end{array}$ & NS/NS & NS & NS \\
\hline
\end{tabular}


Table 2 (continued)

\begin{tabular}{|c|c|c|c|c|c|c|c|}
\hline Study & $\begin{array}{l}\text { Diabetes } \\
\text { incidence } \\
(\%)^{*}\end{array}$ & Components of score & $\begin{array}{c}\text { Sensitivity/specificity } \dagger \\
\%\end{array}$ & $\begin{array}{l}\text { AUROC } \\
(95 \% \mathrm{Cl})\end{array}$ & $\begin{array}{c}\text { Positive/negative } \\
\text { predictive value } \\
(\%)\end{array}$ & Calibration & $\begin{array}{c}\% \\
\text { needing } \\
\text { further } \\
\text { tests }\end{array}$ \\
\hline Chuang $2011^{38}$ & 6.4 & $\begin{array}{l}\text { Age, sex, education, alcohol, BMI, } \\
\text { waist circumference, triglyceride level, } \\
\text { blood pressure, hypertension, fasting } \\
\text { plasma glucose level }\end{array}$ & NS/NS & $\begin{array}{l}0.82(0.81 \text { to } \\
0.83)\end{array}$ & NS/NS & NS & NS \\
\hline Chuang $2011^{38}$ & 6.4 & $\begin{array}{l}\text { Age, sex, education, alcohol, BMI, } \\
\text { waist circumference, family history of } \\
\text { diabetes }\end{array}$ & NS/NS & $\begin{array}{l}0.75(0.73- \\
0.78)\end{array}$ & NS/NS & NS & NS \\
\hline Chuang $2011^{38}$ & 6.4 & $\begin{array}{l}\text { Age, sex, education, family history of } \\
\text { diabetes, alcohol, BMI, waist } \\
\text { circumference, blood pressure, } \\
\text { hypertension }\end{array}$ & NS/NS & $\begin{array}{l}0.76(0.73 \text { to } \\
0.79)\end{array}$ & NS/NS & NS & NS \\
\hline Chuang $2011^{38}$ & 6.4 & $\begin{array}{l}\text { Age, sex, education, alcohol } \\
\text { consumption, BMI, waist } \\
\text { circumference, blood pressure, } \\
\text { hypertension, fasting plasma glucose } \\
\text { level, triglyceride level, family history } \\
\text { of diabetes }\end{array}$ & NS/NS & $\begin{array}{l}0.84(0.81 \text { to } \\
0.86)\end{array}$ & NS/NS & NS & NS \\
\hline Collins $2011^{57}$ & 3.0 & $\begin{array}{l}\text { Age, sex, ethnicity, BMI, smoking, } \\
\text { family history of diabetes, } \\
\text { cardiovascular disease, Townsend } \\
\text { score, treated high blood pressure, } \\
\text { current use of corticosteroids }\end{array}$ & NS/NS & $\begin{array}{l}\text { Women } 0.81 \text {, } \\
\text { men } 0.80\end{array}$ & NS/NS & $\begin{array}{l}\text { Brier score: men } \\
0.053(0.051-0.054) \\
\text { women } 0.041 \\
(0.040-0.043)\end{array}$ & NS \\
\hline Gao $2009^{39}$ & 16.5 & $\begin{array}{l}\text { BMI, waist circumference, family } \\
\text { history of diabetes }\end{array}$ & $\begin{array}{l}\text { Men } 72(71-74) / 0.47 \\
(0.45-0.49), \text { women } 77 \\
(75-78) / 0.50(0.48-0.52)\end{array}$ & $\begin{array}{l}\text { Men } 0.62 \\
(0.56 \text { to } \\
0.68) \\
\text { women } 0.64 \\
\text { (0.59 to } 0.69)\end{array}$ & NS/NS & NS & NS \\
\hline $\begin{array}{l}\text { Guerrero-Romero } \\
2010^{58}\end{array}$ & 11.8 & $\begin{array}{l}\text { Age, sex, family history of diabetes, } \\
\text { family history of hypertension, family } \\
\text { history of obesity, history of } \\
\text { gestational diabetes or macrosomia, } \\
\text { fasting plasma glucose level, physical } \\
\text { inactivity, triglyceride level, systolic } \\
\text { or diastolic blood pressure, BMI }\end{array}$ & $92 / 71$ & 0.91 & $35 / 97.5$ & NS & NS \\
\hline $\begin{array}{l}\text { Hippisley-Cox } \\
2009^{8}\end{array}$ & 3.1 & $\begin{array}{l}\text { Age, sex, ethnicity, BMI, smoking, } \\
\text { family history of diabetes, Townsend } \\
\text { score, treated hypertension, } \\
\text { cardiovascular disease, current use } \\
\text { of corticosteroids }\end{array}$ & NS/NS & NS & NS/NS & NS & NS \\
\hline $\begin{array}{l}\text { Hippisley-Cox } \\
2009^{8}\end{array}$ & 3.0 & $\begin{array}{l}\text { Age, sex, ethnicity, BMI, smoking, } \\
\text { family history of diabetes, Townsend } \\
\text { score, treated hypertension, } \\
\text { cardiovascular disease, current use } \\
\text { of corticosteroids }\end{array}$ & NS/NS & $\begin{array}{l}\text { Women } 0.85 \\
(0.85 \text { to } \\
0.86) \text {, men } \\
0.83(0.83 \text { to } \\
0.84)\end{array}$ & NS/NS & $\begin{array}{l}\text { Brier score: men } \\
0.078(0.075-0.080) \\
\text { women } 0.058 \\
(0.055-0.060)\end{array}$ & NS \\
\hline Joseph $2010^{40}$ & $\begin{array}{l}\text { Men } 2.5, \\
\text { women } 1.5\end{array}$ & $\begin{array}{l}\text { Age, BMI, total cholesterol, } \\
\text { triglyceride level, high density } \\
\text { lipoprotein cholesterol level, } \\
\text { hypertension, family history of } \\
\text { diabetes, education, physical } \\
\text { inactivity, smoking }\end{array}$ & NS/NS & $\begin{array}{l}\text { Men } 0.87 \\
\text { women } 0.88\end{array}$ & NS/NS & NS & NS \\
\hline Kahn $2009^{41}$ & $\begin{array}{l}\text { Men } 19.4 \\
\text { women } \\
18.6\end{array}$ & $\begin{array}{l}\text { See next two rows for description of } \\
\text { both models }\end{array}$ & NS/NS & NS & NS/NS & NS & NS \\
\hline Kahn $2009^{41}$ & $\begin{array}{l}17.7 \text { at } 10 \\
\text { years }\end{array}$ & $\begin{array}{l}\text { Waist circumference, parental history } \\
\text { of diabetes, hypertension, short } \\
\text { stature, black race, age }>55 \text {, weight, } \\
\text { pulse, smoking }\end{array}$ & $69 / 64$ & $\begin{array}{l}0.71(0.69 \text { to } \\
0.73)\end{array}$ & NS/NS & NS & NS \\
\hline
\end{tabular}


Table 2 (continued)

\begin{tabular}{|c|c|c|c|c|c|c|c|}
\hline Study & $\begin{array}{l}\text { Diabetes } \\
\text { incidence } \\
(\%)^{\star}\end{array}$ & Components of score & $\begin{array}{c}\text { Sensitivity/specificity } \dagger \\
\%\end{array}$ & $\begin{array}{l}\text { AUROC } \\
(95 \% \mathrm{CI})\end{array}$ & $\begin{array}{l}\text { Positive/negative } \\
\text { predictive value } \\
\text { (\%) }\end{array}$ & Calibration & $\begin{array}{c}\% \\
\text { needing } \\
\text { further } \\
\text { tests }\end{array}$ \\
\hline Kahn $2009^{41}$ & $\begin{array}{l}17.7 \text { at } 10 \\
\text { years }\end{array}$ & $\begin{array}{l}\text { Glucose, waist circumference, } \\
\text { parental history of diabetes, } \\
\text { hypertension, triglyceride level, black } \\
\text { race, high density lipoprotein } \\
\text { cholesterol level, short stature, high } \\
\text { uric acid level, age }>55 \text {, pulse, } \\
\text { alcohol consumption }\end{array}$ & $74 / 71$ & $\begin{array}{l}0.79(0.77 \text { to } \\
0.81)\end{array}$ & NS/NS & NS & NS \\
\hline Kanaya $2005^{59}$ & 5.7 & $\begin{array}{l}\text { Age, sex, triglyceride level, fasting } \\
\text { plasma glucose level }\end{array}$ & NS/NS & 0.71 (NS) & NS/NS & NS & NS \\
\hline Kolberg $2009^{42}$ & 2.7 & $\begin{array}{l}\text { Six biomarkers: adiponectin, } C \\
\text { reactive protein, ferritin, glucose, } \\
\text { interleukin } 2 \text { receptor } A \text {, insulin }\end{array}$ & NS/NS & 0.78 (NS) & NS/NS & NS & $\begin{array}{l}10 \% \\
\text { classified } \\
\text { as high } \\
\text { risk }\end{array}$ \\
\hline Lindstrom $2003^{68}$ & 4.1 & $\begin{array}{l}\text { Age, BMI, waist circumference, use } \\
\text { of antihypertensive drugs, history of } \\
\text { hypertension, physical inactivity, diet } \\
\text { (vegetables, fruits or berries) }\end{array}$ & $78(71-84) / 77(76-79)$ & 0.85 (NS) & $\begin{array}{l}0.13 \\
(0.11-0.15) / 0.99 \\
(0.98-0.99)\end{array}$ & NS & $\begin{array}{l}25 \% \text { in } \\
\text { two } \\
\text { highest } \\
\text { risk } \\
\text { categories }\end{array}$ \\
\hline Lindstrom $2003^{68}$ & 1.5 & $\begin{array}{l}\text { Age, BMI, waist circumference, use } \\
\text { of antihypertensive drugs, history of } \\
\text { hypertension, physical inactivity, diet } \\
\text { (vegetables, fruit or berries) }\end{array}$ & $81(69-89) / 76(74-77)$ & 0.87 (NS) & $\begin{array}{l}0.05 \\
(0.04-0.06) / 0.996 \\
(0.993-0.998)\end{array}$ & NS & $\begin{array}{l}26 \% \text { of } \\
\text { men and } \\
24 \% \text { of } \\
\text { women in } \\
\text { two } \\
\text { highest } \\
\text { risk } \\
\text { categories }\end{array}$ \\
\hline Liu $2011^{43}$ & 20.9 & $\begin{array}{l}\text { Age, hypertension, history of high } \\
\text { blood glucose level, BMI }\end{array}$ & NS/NS & $\begin{array}{l}0.68(0.65 \text { to } \\
0.72)\end{array}$ & NS/NS & NS & NS \\
\hline Liu $2011^{43}$ & 20.9 & $\begin{array}{l}\text { Age, hypertension, history of high } \\
\text { blood glucose level, BMI, fasting } \\
\text { plasma glucose level }\end{array}$ & NS/NS & $\begin{array}{l}0.71(0.68 \text { to } \\
0.74)\end{array}$ & NS/NS & NS & NS \\
\hline Liu $2011^{43}$ & 20.9 & $\begin{array}{l}\text { Age, hypertension, history of high } \\
\text { blood glucose level, BMI, fasting } \\
\text { plasma glucose level, triglyceride } \\
\text { level, high density lipoprotein } \\
\text { cholesterol level }\end{array}$ & $64.5 / 71.6$ & $\begin{array}{l}0.72(0.69 \text { to } \\
0.76)\end{array}$ & $37.70 / 88.60$ & NS & NS \\
\hline Mainous $2007^{60}$ & 3.9 & $\begin{array}{l}\text { Waist circumference, hypertension or } \\
\text { use of antihypertensive drugs, low } \\
\text { density lipoprotein cholesterol level, } \\
\text { triglyceride level, BMI, } \\
\text { hyperglycaemia }\end{array}$ & $15 / 98$ & 0.70 & NS/NS & NS & NS \\
\hline Mann $2010^{19}$ & 8.4 & $\begin{array}{l}\text { Overweight or obese, impaired fasting } \\
\text { glucose, high density lipoprotein } \\
\text { cholesterol level, triglyceride level, } \\
\text { hypertension, parental history of } \\
\text { diabetes }\end{array}$ & NS/NS & $\begin{array}{l}0.78(0.74 \text { to } \\
0.82)\end{array}$ & NS/NS & $\begin{array}{l}\text { Hosmer-Lemeshow } \\
P<0.001 \text { before } \\
\text { calibration, } P>0.10 \\
\text { after recalibration }\end{array}$ & $\begin{array}{l}27.7 \text { in } \\
\text { highest } \\
\text { risk fifth }\end{array}$ \\
\hline Mann $2010^{19}$ & 8.4 & $\begin{array}{l}\text { Height, waist circumference, black } \\
\text { ethnicity, systolic blood pressure, } \\
\text { fasting plasma glucose level, high } \\
\text { density lipoprotein cholesterol level, } \\
\text { triglyceride level, parental history of } \\
\text { diabetes, age }\end{array}$ & NS/NS & $\begin{array}{l}0.84(0.82 \text { to } \\
0.86)\end{array}$ & NS/NS & $\begin{array}{l}\text { Hosmer-Lemeshow } \\
P<0.001 \text { before } \\
\text { calibration, } P>0.10 \\
\text { after recalibration }\end{array}$ & $\begin{array}{l}27.6 \text { in } \\
\text { highest } \\
\text { risk fifth }\end{array}$ \\
\hline Mann $2010^{19}$ & 8.4 & $\begin{array}{l}\text { Age, sex, Mexican-American } \\
\text { ethnicity, fasting plasma glucose } \\
\text { level, systolic blood pressure, high } \\
\text { density lipoprotein cholesterol level, } \\
\text { BMI, family history of diabetes }\end{array}$ & NS/NS & $\begin{array}{l}0.83(0.81 \text { to } \\
0.85)\end{array}$ & NS/NS & $\begin{array}{l}\text { Hosmer-Lemeshow } \\
P<0.001 \text { before } \\
\text { calibration, } P>0.10 \\
\text { after recalibration }\end{array}$ & $\begin{array}{l}27.6 \text { in } \\
\text { highest } \\
\text { risk fifth }\end{array}$ \\
\hline McNeely $2003^{61}$ & $\begin{array}{l}9.7 \text { at } 5 \\
\text { years } 14.3 \\
\text { at } 10 \text { years }\end{array}$ & $\begin{array}{l}\text { Age, sex, ethnicity, BMI, systolic } \\
\text { blood pressure, fasting plasma } \\
\text { glucose level, high density lipoprotein } \\
\text { cholesterol level, family history of } \\
\text { diabetes in first degree relative }\end{array}$ & $\begin{array}{l}60 \text { and } 73.3 \text { at } 5-6 \\
\text { years/64.9 and } 78.4 \text { at } \\
10 \text { years }\end{array}$ & $\begin{array}{l}0.76(0.70 \text { to } \\
0.81) \text { at } 5-6 \\
\text { years, } 0.79 \\
(0.74 \text { to } 0.85) \\
\text { at } 10 \text { years }\end{array}$ & NS/NS & NS & NS \\
\hline
\end{tabular}


Table 2 (continued)

\begin{tabular}{|c|c|c|c|c|c|c|c|}
\hline Study & $\begin{array}{c}\text { Diabetes } \\
\text { incidence } \\
(\%)^{\star}\end{array}$ & Components of score & $\begin{array}{c}\text { Sensitivity/specificity } \dagger \\
\%\end{array}$ & $\begin{array}{l}\text { AUROC } \\
(95 \% \mathrm{Cl})\end{array}$ & $\begin{array}{c}\text { Positive/negative } \\
\text { predictive value } \\
(\%)\end{array}$ & Calibration & $\begin{array}{c}\% \\
\text { needing } \\
\text { further } \\
\text { tests }\end{array}$ \\
\hline Mehrabi $2010^{44}$ & 4.2 & $\begin{array}{l}\text { Impaired fasting glucose, family } \\
\text { history of diabetes, impaired glucose } \\
\text { tolerance, waist circumference, } \\
\text { triglyceride level }\end{array}$ & NS/NS & $\begin{array}{l}0.843(0.813 \\
\text { to } 0.874)\end{array}$ & NS/NS & NS & NS \\
\hline Meigs $^{9}$ & 9.2 & $\begin{array}{l}\text { Age, sex, family history of diabetes, } \\
\text { BMI, triglyceride level, fasting plasma } \\
\text { glucose level, systolic blood pressure, } \\
\text { high density lipoprotein cholesterol } \\
\text { level (Framingham simple clinical } \\
\text { model) }\end{array}$ & NS/NS & $\begin{array}{l}0.90(0.88 \text { to } \\
0.92)\end{array}$ & NS/NS & NS & NS \\
\hline Nichols $2008^{62}$ & 16.5 & $\begin{array}{l}\text { Age, sex, parental history of diabetes, } \\
\text { BMI }\end{array}$ & NS/NS & 0.68 (NS) & NS/NS & NS & NS \\
\hline Nichols $2008^{62}$ & 16.5 & $\begin{array}{l}\text { Age, sex, parental history of diabetes, } \\
\text { BMI, hypertension or antihypertensive } \\
\text { drugs, high density lipoprotein } \\
\text { cholesterol level, triglyceride level, } \\
\text { fasting plasma glucose level }\end{array}$ & NS/NS & 0.82 (NS) & NS/NS & $\begin{array}{l}\text { Hosmer-Lemeshow } \\
\mathrm{P}<0.001\end{array}$ & NS \\
\hline Nichols $2008^{62}$ & 16.5 & $\begin{array}{l}\text { Age, sex, parental history of diabetes, } \\
\text { BMI, systolic blood pressure, high } \\
\text { density lipoprotein cholesterol level, } \\
\text { triglyceride level, fasting plasma } \\
\text { glucose level, waist circumference }\end{array}$ & NS/NS & 0.84 (NS) & NS/NS & NS & NS \\
\hline Rahman $2008^{63}$ & 1.3 & $\begin{array}{l}\text { Age, sex, current use of } \\
\text { corticosteroids, use of } \\
\text { antihypertensive drugs, family history } \\
\text { of diabetes, BMI, smoking }\end{array}$ & $54.5 / 80$ & 0.74 (NS) & NS/NS & NS & 20 \\
\hline Rathmann $2010^{85}$ & 7.6 & $\begin{array}{l}\text { Age, sex, BMI, parental history of } \\
\text { diabetes, smoking, hypertension }\end{array}$ & $69.2 / 74$ & $\begin{array}{l}0.76(0.71 \text { to } \\
0.81)\end{array}$ & $23.7 / 95.4$ & $\begin{array}{l}\text { Hosmer-Lemeshow } \\
P=0.66 \text {, Brier score } \\
0.0848\end{array}$ & NS \\
\hline Rathmann $2010^{85}$ & 7.6 & $\begin{array}{l}\text { Age, sex, BMI, parental history of } \\
\text { diabetes, smoking, hypertension, } \\
\text { fasting plasma glucose level, } \\
\text { haemoglobin } \mathrm{A}_{1 \mathrm{c}} \text { concentration, uric } \\
\text { acid level }\end{array}$ & $82.4 / 72.9$ & $\begin{array}{l}0.84(0.80 \text { to } \\
0.89)\end{array}$ & $26.1 / 97.3$ & $\begin{array}{l}\text { Hosmer-Lemeshow } \\
P=0.45 \text {, Brier score } \\
0.0716\end{array}$ & NS \\
\hline Rathmann $2010^{85}$ & 7.6 & $\begin{array}{l}\text { Age, sex, BMI, parental history of } \\
\text { diabetes, smoking, hypertension, } \\
\text { fasting plasma glucose level, } \\
\text { haemoglobin } \mathrm{A}_{1 \mathrm{c}} \text { concentration, uric } \\
\text { acid level, oral glucose tolerance test }\end{array}$ & $81.3 / 84.1$ & $\begin{array}{l}0.89(0.85 \text { to } \\
0.92)\end{array}$ & $37.4 / 97.5$ & $\begin{array}{l}\text { Hosmer-Lemeshow } \\
P=0.70 \text {, Brier score } \\
0.0652\end{array}$ & NS \\
\hline Rosella $2010^{69}$ & 7.1 & $\begin{array}{l}\text { Age, ethnicity, BMI, hypertension, } \\
\text { immigrant status, smoking, education, } \\
\text { cardiovascular disease }\end{array}$ & NS/NS & $\begin{array}{l}\text { Men } 0.77 \\
(0.76 \text { to } \\
0.79) \\
\text { women } 0.78 \\
(0.76 \text { to } 0.79)\end{array}$ & NS/NS & Hosmer-Lemeshow & NS \\
\hline Rosella $2010^{69}$ & 5.3 & $\begin{array}{l}\text { Age, ethnicity, BMI, hypertension, } \\
\text { immigrant status, smoking, education, } \\
\text { cardiovascular disease }\end{array}$ & NS/NS & $\begin{array}{l}\text { Men } 0.77 \\
(0.76 \text { to } \\
0.79) \\
\text { women } 0.76 \\
(0.74 \text { to } 0.77)\end{array}$ & NS/NS & Hosmer-Lemeshow & NS \\
\hline Rosella $2010^{69}$ & 4.2 & $\begin{array}{l}\text { Age, ethnicity, BMI, hypertension, } \\
\text { immigrant status, smoking, education, } \\
\text { cardiovascular disease }\end{array}$ & NS/NS & $\begin{array}{l}\text { Men } 0.79 \\
(0.77 \text { to } \\
0.82) \\
\text { women } 0.80 \\
(0.77 \text { to } 0.82)\end{array}$ & NS/NS & Hosmer-Lemeshow & NS \\
\hline Schmidt $2005^{46}$ & 16.3 & $\begin{array}{l}\text { Age, waist circumference, height, } \\
\text { systolic blood pressure, family history } \\
\text { of diabetes, ethnicity }\end{array}$ & $\begin{array}{l}\text { Range } 40-77 / 55-84 \text { (at } \\
\text { different cut-offs) }\end{array}$ & 0.71 & $\begin{array}{l}\text { Range } \\
25-32 / \text { range } 88-93 \\
\text { (at different } \\
\text { cut-offs) }\end{array}$ & NS & 50 \\
\hline Schmidt $2005^{46}$ & 16.3 & $\begin{array}{l}\text { Age, waist circumference, height, } \\
\text { systolic blood pressure, family history } \\
\text { of diabetes, ethnicity, fasting plasma } \\
\text { glucose level }\end{array}$ & $\begin{array}{l}\text { Range } 51-83 / 56-86 \text { (at } \\
\text { different cut-offs) }\end{array}$ & 0.78 & $\begin{array}{l}\text { Range } \\
27-41 / 90-94 \text { (at } \\
\text { different cut-offs) }\end{array}$ & NS & 50 \\
\hline
\end{tabular}


Table 2 (continued)

\begin{tabular}{|c|c|c|c|c|c|c|c|}
\hline Study & $\begin{array}{l}\text { Diabetes } \\
\text { incidence } \\
(\%)^{\star}\end{array}$ & Components of score & $\begin{array}{c}\text { Sensitivity/specificity } \dagger \\
\%\end{array}$ & $\begin{array}{l}\text { AUROC } \\
(95 \% \mathrm{Cl})\end{array}$ & $\begin{array}{l}\text { Positive/negative } \\
\text { predictive value } \\
\text { (\%) }\end{array}$ & Calibration & $\begin{array}{c}\% \\
\text { needing } \\
\text { further } \\
\text { tests }\end{array}$ \\
\hline Schmidt $2005^{46}$ & 16.3 & $\begin{array}{l}\text { Age, ethnicity, waist circumference, } \\
\text { height, systolic blood pressure, family } \\
\text { history of diabetes, fasting plasma } \\
\text { glucose level, triglyceride level, high } \\
\text { density lipoprotein cholesterol level }\end{array}$ & $\begin{array}{l}\text { Range } 52-85 / 57-86 \text { (at } \\
\text { different cut-offs) }\end{array}$ & 0.80 & $\begin{array}{l}\text { Range } \\
27-42 / \text { range } 90-95 \\
\text { (at different } \\
\text { cut-offs) }\end{array}$ & NS & 50 \\
\hline Schulze $2007^{70}$ & 3.1 & $\begin{array}{l}\text { Age, waist circumference, height, } \\
\text { history of hypertension, physical } \\
\text { inactivity, smoking, consumption of } \\
\text { red meat, whole grain bread, coffee, } \\
\text { and alcohol }\end{array}$ & $\begin{array}{l}83.1,67.5,50.3 / 68.3 \\
80.6,89.9 \text { (at different } \\
\text { cut-offs) }\end{array}$ & 0.84 & $\begin{array}{l}5.9,7.7,10.7 \text { at } \\
\text { different } \\
\text { cut-offs/NS }\end{array}$ & $\begin{array}{l}\text { Observed to } \\
\text { predicted incidence }\end{array}$ & 23.20 \\
\hline Schulze $2007^{70}$ & 2.6 & $\begin{array}{l}\text { Age, waist circumference, height, } \\
\text { history of hypertension, physical } \\
\text { inactivity, smoking, consumption of } \\
\text { red meat, whole grain bread, coffee, } \\
\text { and alcohol }\end{array}$ & $\begin{array}{l}94.4 \geq 500 \text { points, } 79.7 \\
\geq 550 \text { points } 66.7 \geq 500 \\
\text { points, } 79.3 \geq 550 \text { points }\end{array}$ & 0.82 & NS/NS & $\begin{array}{l}\text { Observed to } \\
\text { predicted incidence }\end{array}$ & NS \\
\hline Schulze $2009^{47}$ & 3 & $\begin{array}{l}\text { Diabetes risk score plus haemoglobin } \\
\mathrm{A}_{1 \mathrm{c}} \text { concentration, glucose level, } \\
\text { triglyceride level, high density } \\
\text { lipoprotein cholesterol level, } \\
\text { y-glutamyltransferase level, alanine } \\
\text { aminotransferase level }\end{array}$ & NS/NS & $\begin{array}{l}0.90(0.89 \text { to } \\
0.91)\end{array}$ & NS/NS & $\begin{array}{l}\text { Hosmer-Lemeshow } \\
\text { tests showed better } \\
\text { calibration with } \\
\text { haemoglobin } \mathrm{A}_{1 \mathrm{c}} \text { or } \\
\text { glucose included }\end{array}$ & NS \\
\hline Simmons $2007^{71}$ & 1.7 & $\begin{array}{l}\text { Age, sex, use of antihypertensive } \\
\text { drugs, BMI, family history of diabetes, } \\
\text { physical inactivity, diet (green leafy } \\
\text { vegetables, fresh fruit, wholemeal } \\
\text { bread) }\end{array}$ & NS/NS & $\begin{array}{l}0.76(0.73 \text { to } \\
0.79)\end{array}$ & NS/NS & NS & NS \\
\hline Simmons $2007^{71}$ & 1.7 & $\begin{array}{l}\text { Age, sex, current use of } \\
\text { corticosteroids, use of } \\
\text { antihypertensive drugs, family history } \\
\text { of diabetes, BMI, smoking }\end{array}$ & NS/NS & $\begin{array}{l}0.76(0.73 \text { to } \\
0.79)\end{array}$ & NS/NS & NS & NS \\
\hline Stern $1993^{48}$ & 3.7 & $\begin{array}{l}\text { Fasting plasma glucose level, two } \\
\text { hour postprandial plasma glucose } \\
\text { level, BMI, high density lipoprotein } \\
\text { cholesterol level, pulse pressure }\end{array}$ & $75 / 88.5$ & NS & $26.80 / 98.40$ & NS & 12.8 \\
\hline Stern $1993^{48}$ & 3.7 & $\begin{array}{l}\text { Sex, fasting plasma glucose level, } \\
\text { BMI, high density lipoprotein } \\
\text { cholesterol level, pulse pressure }\end{array}$ & $69.6 / 88.1$ & NS & $25.20 / 98.10$ & NS & 14.7 \\
\hline Stern $2002^{86}$ & 6.0 & $\begin{array}{l}\text { Age, sex, ethnicity, triglyceride level, } \\
\text { total cholesterol level, low and high } \\
\text { density lipoprotein cholesterol levels, } \\
\text { fasting plasma glucose level, family } \\
\text { history of diabetes in first degree } \\
\text { relative, two hour postprandial plasma } \\
\text { glucose level, systolic and diastolic } \\
\text { blood pressure, BMI }\end{array}$ & NS/NS & $\begin{array}{l}0.86(0.84 \text { to } \\
0.88)\end{array}$ & NS/NS & $\begin{array}{l}\text { Hosmer-Lemeshow } \\
P>0.2\end{array}$ & NS \\
\hline Stern $2002^{86}$ & $6 / 0$ & $\begin{array}{l}\text { Age, sex, ethnicity, fasting plasma } \\
\text { glucose level, systolic blood pressure, } \\
\text { high density lipoprotein cholesterol } \\
\text { level, BMI, family history of diabetes } \\
\text { in first degree relative }\end{array}$ & NS/NS & $\begin{array}{l}0.84(0.82 \text { to } \\
0.87)\end{array}$ & NS/NS & $\begin{array}{l}\text { Hosmer-Lemeshow } \\
P>0.2\end{array}$ & NS \\
\hline Sun $2009^{72}$ & 4.7 & $\begin{array}{l}\text { Age, sex, education, family history of } \\
\text { diabetes, smoker, sport time, high } \\
\text { blood pressure, BMI, waist } \\
\text { circumference, fasting plasma } \\
\text { glucose level }\end{array}$ & 72.3/82.8 & $\begin{array}{l}0.85(0.83 \text { to } \\
0.87)\end{array}$ & $17.18 / 98.38$ & $\begin{array}{l}\text { Observed to } \\
\text { predicted incidence } \\
P=0.410\end{array}$ & 31.2 \\
\hline Sun $2009^{72}$ & 4.7 & $\begin{array}{l}\text { Age, ethnicity, waist circumference, } \\
\text { height, systolic blood pressure, family } \\
\text { history of diabetes, fasting plasma } \\
\text { glucose level }\end{array}$ & $75.2 / 79.0$ & 0.84 & $13.54 / 98.47$ & NS & 23.5 \\
\hline
\end{tabular}


Table 2 (continued)

\begin{tabular}{|c|c|c|c|c|c|c|c|}
\hline Study & $\begin{array}{l}\text { Diabetes } \\
\text { incidence } \\
(\%)^{\star}\end{array}$ & Components of score & $\begin{array}{c}\text { Sensitivity/specificity } \dagger \\
\%\end{array}$ & $\begin{array}{l}\text { AUROC } \\
(95 \% \mathrm{CI})\end{array}$ & $\begin{array}{l}\text { Positive/negative } \\
\text { predictive value } \\
\text { (\%) }\end{array}$ & Calibration & $\begin{array}{c}\% \\
\text { needing } \\
\text { further } \\
\text { tests }\end{array}$ \\
\hline Sun $2009^{72}$ & 4.7 & $\begin{array}{l}\text { Age, ethnicity, waist circumference, } \\
\text { height, systolic blood pressure, family } \\
\text { history of diabetes, fasting plasma } \\
\text { glucose level, triglyceride level, high } \\
\text { density lipoprotein cholesterol level }\end{array}$ & $75.0 / 79.7$ & 0.84 & $15.39 / 98.47$ & NS & 22.7 \\
\hline Talmud $2010^{10}$ & 3.5 & NS & NS/NS & $\begin{array}{l}0.72(0.69 \text { to } \\
0.76)\end{array}$ & NS/NS & $\begin{array}{l}\text { Hosmer-Lemeshow } \\
\mathrm{P}=0.77\end{array}$ & 19.2 \\
\hline Talmud $2010^{10}$ & 3.5 & NS & NS/NS & $\begin{array}{l}0.78(0.75 \text { to } \\
0.82)\end{array}$ & NS/NS & $\begin{array}{l}\text { Hosmer-Lemeshow } \\
\mathrm{P}=0.42\end{array}$ & 26.6 \\
\hline Urdea $2009^{64}$ & 3.2 & $\begin{array}{l}\text { Levels of adiponectin, } C \text { reactive } \\
\text { protein, ferritin, glucose, haemoglobin } \\
A_{1 c} \text {, interleukin } 2 \text {, insulin }\end{array}$ & NS/NS & 0.84 (NS) & NS/NS & $\begin{array}{l}\text { Observed to } \\
\text { predicted risk }\end{array}$ & NS \\
\hline Urdea $2009^{64}$ & 3.2 & $\begin{array}{l}\text { Levels of adiponectin, } C \text { reactive } \\
\text { protein, ferritin, glucose, haemoglobin } \\
A_{1 c} \text {, interleukin } 2 \text {, insulin }\end{array}$ & NS/NS & 0.84 (NS) & NS/NS & $\begin{array}{l}\text { Observed to } \\
\text { predicted risk }\end{array}$ & NS \\
\hline $\begin{array}{l}\text { Von Eckardstein } \\
2000^{50}\end{array}$ & 5.4 & $\begin{array}{l}\text { Age, BMI, hypertension, glucose, } \\
\text { family history of diabetes, high } \\
\text { density lipoprotein cholesterol level }\end{array}$ & $\begin{array}{l}69.5(62.6-73.9) \text { at } 80 \% \\
\text { specificity, } 57.0 \\
(49.8-64.0) \text { at } 90 \% \\
\text { specificity/set at } 80 \% \\
\text { and } 90 \%\end{array}$ & $\begin{array}{l}0.79(0.78 \text { to } \\
0.81)\end{array}$ & $\begin{array}{l}16.7 \text { at } 80 \% \\
\text { specificity, } 24.6 \text { at } \\
90 \% \text { specificity/NS }\end{array}$ & NS & NS \\
\hline $\begin{array}{l}\text { Wannamethee } \\
2011^{27}\end{array}$ & 4.3 & $\begin{array}{l}\text { Age, sex, family history of diabetes, } \\
\text { smoking status, BMI, waist } \\
\text { circumference, hypertension, recall } \\
\text { of doctor diagnosed coronary heart } \\
\text { disease }\end{array}$ & $\begin{array}{l}79.2 \text { (top } 40 \% \text { ) } 50.3 \text { (top } \\
20 \% \text { )/61.8 (top } 40 \% \text { ) } \\
81.4 \text { (top } 20 \% \text { ) }\end{array}$ & $\begin{array}{l}0.77(0.74 \text { to } \\
0.79)\end{array}$ & NS/NS & $\begin{array}{l}\text { Hosmer-Lemeshow } \\
P=0.006\end{array}$ & 47 \\
\hline $\begin{array}{l}\text { Wannamethee } \\
2011^{27}\end{array}$ & 4.3 & $\begin{array}{l}\text { Age, sex, family history of diabetes, } \\
\text { fasting plasma glucose level, smoking } \\
\text { status, BMI, waist circumference, } \\
\text { hypertension, recall of doctor } \\
\text { diagnosed coronary heart disease, } \\
\text { high density lipoprotein cholesterol } \\
\text { level, triglyceride level }\end{array}$ & $\begin{array}{l}84.2 \text { (top } 40 \% \text { ), } 63.8 \text { (top } \\
20 \%) / 62 \% \text { (top } 40 \% \text { ) } 82 \\
\text { (top } 20 \% \text { ) }\end{array}$ & $\begin{array}{l}0.82(0.79 \text { to } \\
0.84)\end{array}$ & NS/NS & $\begin{array}{l}\text { Hosmer-Lemeshow } \\
P=0.43\end{array}$ & NS \\
\hline $\begin{array}{l}\text { Wannamethee } \\
2011^{27}\end{array}$ & 4.3 & $\begin{array}{l}\text { Age, sex, family history of diabetes, } \\
\text { smoking, BMI, waist circumference, } \\
\text { hypertension, recall of doctor } \\
\text { diagnosed coronary heart disease, } \\
\text { high density lipoprotein cholesterol } \\
\text { level, Y-glutamyltransferase level,, } \\
\text { haemoglobin } \mathrm{A}_{1 \mathrm{c}} \text { concentration }\end{array}$ & $\begin{array}{l}85.1 \text { (top } 40 \% \text { ), } 62 \% \text { (top } \\
20 \% \text { )/62.1 (top } 40 \% \text { ), } \\
82 \% \text { (top } 20 \% \text { ) }\end{array}$ & $\begin{array}{l}0.81(0.79 \text { to } \\
0.83)\end{array}$ & NS/NS & $\begin{array}{l}\text { Hosmer-Lemeshow } \\
\mathrm{P}=0.61\end{array}$ & NS \\
\hline $\begin{array}{l}\text { Wannamethee } \\
2005^{65}\end{array}$ & 5.8 & NS & $\begin{array}{l}35.6 / 75.7 \text { (both at } 20 \\
\text { years) }\end{array}$ & $\begin{array}{l}0.60(0.56 \text { to } \\
0.64) \text { at } 20 \\
\text { years }\end{array}$ & NS/NS & NS & 10.8 \\
\hline Wilson $2007^{51}$ & 5.1 & $\begin{array}{l}\text { Fasting plasma glucose level, BMI, } \\
\text { high density lipoprotein cholesterol } \\
\text { level, parental history of diabetes, } \\
\text { triglyceride level, blood pressure }\end{array}$ & NS/NS & 0.85 (NS) & NS/NS & NS & 15.6 \\
\hline
\end{tabular}

$\mathrm{NS}=$ not stated; $\mathrm{BMI}=$ body mass index.

*Incidence of diabetes was measured differently by different authors, such as annually, every five years, every 10 years, or per 1000 patient years.

†Sensitivity and specificity are based on authors' preferred cut-off score. 


\begin{tabular}{|c|c|c|c|c|c|c|c|c|}
\hline \multirow[b]{2}{*}{ Study } & \multicolumn{2}{|c|}{ Authors' assumptions } & \multirow[b]{2}{*}{$\begin{array}{l}\text { Mechanism } \\
\text { by which } \\
\text { use of risk } \\
\text { score may } \\
\text { improve } \\
\text { outcome }\end{array}$} & \multirow[b]{2}{*}{$\begin{array}{l}\text { Authors' } \\
\text { adjectives to } \\
\text { describe their } \\
\text { risk score }\end{array}$} & \multirow[b]{2}{*}{$\begin{array}{l}\text { Authors' claims } \\
\text { for risk score } \\
\text { over others }\end{array}$} & \multirow[b]{2}{*}{$\begin{array}{l}\text { Authors' stated } \\
\text { concerns about } \\
\text { their risk score }\end{array}$} & \multirow[b]{2}{*}{$\begin{array}{l}\text { Data in } \\
\text { paper on } \\
\text { use of } \\
\text { risk } \\
\text { score in } \\
\text { real } \\
\text { world }\end{array}$} & \multirow{2}{*}{$\begin{array}{c}\text { Citation } \\
\text { tracking } \\
\text { (Google } \\
\text { Scholar) } \\
\text { for } \\
\text { studies } \\
\text { of real } \\
\text { world } \\
\text { use }\end{array}$} \\
\hline & $\begin{array}{l}\text { Who will use risk } \\
\text { score, on which } \\
\text { subgroups or } \\
\text { populations }\end{array}$ & $\begin{array}{l}\text { What will be } \\
\text { offered to } \\
\text { people who } \\
\text { score above } \\
\text { cut-off for } \\
\text { "caseness" }\end{array}$ & & & & & & \\
\hline Aekplakorn $2006^{7}$ & $\begin{array}{l}\text { "Primary health care" } \\
\text { will use score on } \\
\text { "individuals who are } \\
\text { likely to develop } \\
\text { diabetes" }\end{array}$ & $\begin{array}{l}\text { Fasting plasma } \\
\text { glucose test, } \\
\text { "health education } \\
\text { and the } \\
\text { opportunity to } \\
\text { engage in } \\
\text { healthy lifestyles" }\end{array}$ & Clinical & $\begin{array}{l}\text { Simple, "a } \\
\text { practical tool," } \\
\text { low tech, no lab } \\
\text { tests, } \\
\text { non-invasive }\end{array}$ & $\begin{array}{l}\text { "Almost as good as" } \\
\text { and less expensive } \\
\text { than models that } \\
\text { rely on blood tests }\end{array}$ & $\begin{array}{l}\text { Generalisability has } \\
\text { not been shown } \\
\text { beyond Thai } \\
\text { population }\end{array}$ & $\begin{array}{l}\text { Validated } \\
\text { on another } \\
\text { cohort in } \\
\text { same } \\
\text { factory }\end{array}$ & $\begin{array}{l}64 \\
\text { citations, } \\
\text { not } \\
\text { relevant }\end{array}$ \\
\hline Alssema $2008^{52}$ & $\begin{array}{l}\text { General practitioners, } \\
\text { for use on high risk } \\
\text { patients. Public health } \\
\text { clinicians, for use on } \\
\text { high risk populations }\end{array}$ & $\begin{array}{l}\text { Blood test, } \\
\text { preventive } \\
\text { management } \\
\text { according to } \\
\text { protocol }\end{array}$ & $\begin{array}{l}\text { Clinical, public } \\
\text { health }\end{array}$ & "Pretty good" & NS & $\begin{array}{l}\text { Only predicts getting } \\
\text { diabetes, does not } \\
\text { predict complications }\end{array}$ & None & 0 \\
\hline Alssema $2011^{53}$ & $\begin{array}{l}\text { Intended users not } \\
\text { stated. Refined } \\
\text { previous risk score }\end{array}$ & $\begin{array}{l}\text { Blood test, } \\
\text { "integrated } \\
\text { strategies" } \\
\text { (addressing risk } \\
\text { of cardiovascular } \\
\text { disease as well) }\end{array}$ & $\begin{array}{l}\text { Clinical, public } \\
\text { health }\end{array}$ & $\begin{array}{l}\text { Updated, } \\
\text { refined, simple }\end{array}$ & Better discrimination & $\begin{array}{l}\text { Some missing data in } \\
\text { dataset }\end{array}$ & None & $\begin{array}{l}1 \text { citation, } \\
\text { not } \\
\text { relevant }\end{array}$ \\
\hline Balkau $2008^{36}$ & $\begin{array}{l}\text { Implicit target audience } \\
\text { epidemiologists and } \\
\text { population geneticists }\end{array}$ & $\begin{array}{l}\text { Focuses on } \\
\text { population level, } \\
\text { not clinical care } \\
\text { of high risk } \\
\text { people }\end{array}$ & $\begin{array}{l}\text { None } \\
\text { specifically } \\
\text { hypothesised }\end{array}$ & Simple & $\begin{array}{l}\text { Better area under } \\
\text { receiver operating } \\
\text { characteristic curve, } \\
\text { simple (requires } 3 \\
\text { variables for men, } 4 \\
\text { for women) }\end{array}$ & $\begin{array}{l}2 \text { hour glucose level } \\
\text { rarely used in practice }\end{array}$ & None & $\begin{array}{l}34 \\
\text { citations, } \\
\text { not } \\
\text { relevant }\end{array}$ \\
\hline $\begin{array}{l}\text { Bozorgmanesh } \\
2010^{54}\end{array}$ & $\begin{array}{l}\text { Clinical ("targeted } \\
\text { interventions") and } \\
\text { public health ("efficient } \\
\text { allocation of } \\
\text { resources") }\end{array}$ & $\begin{array}{l}\text { "Intensive } \\
\text { diabetes } \\
\text { prevention } \\
\text { interventions" }\end{array}$ & Clinical & $\begin{array}{l}\text { Simple, } \\
\text { parsimonious }\end{array}$ & $\begin{array}{l}\text { Better discrimination } \\
\text { capacity, developed } \\
\text { on large cohort }\end{array}$ & $\begin{array}{l}\text { Sample may not be } \\
\text { representative (too } \\
\text { "urban") }\end{array}$ & None & $\begin{array}{l}1 \text { citation, } \\
\text { not } \\
\text { relevant }\end{array}$ \\
\hline $\begin{array}{l}\text { Bozorgmanesh } \\
2011^{66}\end{array}$ & $\begin{array}{l}\text { Clinicians in Iran and } \\
\text { other Middle Eastern } \\
\text { countries; unselected } \\
\text { Middle Eastern } \\
\text { population }\end{array}$ & NS & Clinical & $\begin{array}{l}\text { Simple, } \\
\text { superior, } \\
\text { pragmatic, } \\
\text { parsimonious, } \\
\text { comprehensive }\end{array}$ & $\begin{array}{l}\text { Better discrimination } \\
\text { capacity, developed } \\
\text { on large cohort }\end{array}$ & NS & None & $\begin{array}{l}2 \text { citations, } \\
\text { not } \\
\text { relevant }\end{array}$ \\
\hline $\begin{array}{l}\text { Bozorgmanesh } \\
2010^{55}\end{array}$ & $\begin{array}{l}\text { Clinical practice ("to be } \\
\text { ordinarily available in a } \\
\text { routine clinical } \\
\text { setting"), Middle } \\
\text { Eastern countries }\end{array}$ & $\begin{array}{l}\text { Formal test for } \\
\text { diabetes, for } \\
\text { example, oral } \\
\text { glucose } \\
\text { tolerance test, } \\
\text { plus } \\
\text { "Individualised } \\
\text { primary } \\
\text { prevention" }\end{array}$ & Clinical & $\begin{array}{l}\text { Simple, clinical, } \\
\text { parsimonious }\end{array}$ & $\begin{array}{l}\text { Likely to be } \\
\text { acceptable to } \\
\text { patients and doctors }\end{array}$ & $\begin{array}{l}\text { Response } 65 \% \text {; short } \\
\text { follow-up, predictive } \\
\text { value reduces with } \\
\text { time }\end{array}$ & NA & 0 \\
\hline Cameron $2008^{56}$ & $\begin{array}{l}\text { Intended users not } \\
\text { stated. Does not } \\
\text { consider how scores } \\
\text { will be used }\end{array}$ & $\begin{array}{l}\text { Implicitly, general } \\
\text { population } \\
\text { (Australians). } \\
\text { "Lifestyle } \\
\text { measures" }\end{array}$ & Clinical & $\begin{array}{l}\text { No better at } \\
\text { predicting } \\
\text { diabetes than } \\
\text { random blood } \\
\text { glucose level }\end{array}$ & NA & $\begin{array}{l}\text { Authors unconvinced } \\
\text { that it adds value }\end{array}$ & NA & $\begin{array}{l}22 \\
\text { citations, } \\
\text { not } \\
\text { relevant }\end{array}$ \\
\hline Chen $2010^{37}$ & $\begin{array}{l}\text { Not stated but score } \\
\text { has been converted to } \\
\text { an online tool for self } \\
\text { assessment of risk by } \\
\text { lay people }\end{array}$ & $\begin{array}{l}\text { "Interventions to } \\
\text { prevent or delay } \\
\text { [diabetes] onset" }\end{array}$ & Lay people & $\begin{array}{l}\text { Simple, } \\
\text { non-invasive }\end{array}$ & $\begin{array}{l}\text { Better } \\
\text { discrimination, } \\
\text { easier to measure } \\
\text { (for example, waist } \\
\text { circumference more } \\
\text { practicable than } \\
\text { BMl for lay people) }\end{array}$ & $\begin{array}{l}\text { Developed on narrow } \\
\text { age band hence age } \\
\text { not very significant in } \\
\text { final model }\end{array}$ & $\begin{array}{l}\text { Validated } \\
\text { on second } \\
\text { population } \\
\text { as part of } \\
\text { this study }\end{array}$ & $\begin{array}{l}6 \text { citations, } \\
\text { of which } \\
\text { one was } \\
\text { an impact } \\
\text { study }\end{array}$ \\
\hline Chien $2009^{67}$ & $\begin{array}{l}\text { "Clinical practice" } \\
\text { (Chinese population) }\end{array}$ & $\begin{array}{l}\text { "Preventive and } \\
\text { treatment } \\
\text { strategies" }\end{array}$ & Clinical & Simple & $\begin{array}{l}\text { First to be validated } \\
\text { in Chinese (but } \\
\text { others claim this } \\
\text { too) }\end{array}$ & $\begin{array}{l}\text { AUROC only } 70 \% \text {, } \\
\text { diabetes not excluded } \\
\text { at baseline }\end{array}$ & None & $\begin{array}{l}24 \\
\text { citations, } \\
\text { not } \\
\text { relevant }\end{array}$ \\
\hline
\end{tabular}


Table 3 (continued)

\begin{tabular}{|c|c|c|c|c|c|c|c|c|}
\hline \multirow[b]{2}{*}{ Study } & \multicolumn{2}{|c|}{ Authors' assumptions } & \multirow[b]{2}{*}{$\begin{array}{l}\text { Mechanism } \\
\text { by which } \\
\text { use of risk } \\
\text { score may } \\
\text { improve } \\
\text { outcome }\end{array}$} & \multirow[b]{2}{*}{$\begin{array}{l}\text { Authors' } \\
\text { adjectives to } \\
\text { describe their } \\
\text { risk score }\end{array}$} & \multirow[b]{2}{*}{$\begin{array}{l}\text { Authors' claims } \\
\text { for risk score } \\
\text { over others }\end{array}$} & \multirow[b]{2}{*}{$\begin{array}{l}\text { Authors' stated } \\
\text { concerns about } \\
\text { their risk score }\end{array}$} & \multirow[b]{2}{*}{$\begin{array}{l}\text { Data in } \\
\text { paper on } \\
\text { use of } \\
\text { risk } \\
\text { score in } \\
\text { real } \\
\text { world }\end{array}$} & \multirow{2}{*}{$\begin{array}{c}\text { Citation } \\
\text { tracking } \\
\text { (Google } \\
\text { Scholar) } \\
\text { for } \\
\text { studies } \\
\text { of real } \\
\text { world } \\
\text { use }\end{array}$} \\
\hline & $\begin{array}{l}\text { Who will use risk } \\
\text { score, on which } \\
\text { subgroups or } \\
\text { populations }\end{array}$ & $\begin{array}{l}\text { What will be } \\
\text { offered to } \\
\text { people who } \\
\text { score above } \\
\text { cut-off for } \\
\text { "caseness" }\end{array}$ & & & & & & \\
\hline Chuang $2011^{38}$ & $\begin{array}{l}\text { "Clinical professionals } \\
\text { and general subjects," } \\
\text { for use in "middle aged } \\
\text { Chinese adults living in } \\
\text { Taiwan" }\end{array}$ & NS & Clinical & Simple & $\begin{array}{l}\text { Menu of scores } \\
\text { (some simple, some } \\
\text { more complex with } \\
\text { better } \\
\text { discrimination); } \\
\text { large validation } \\
\text { cohort }\end{array}$ & None & None & 0 \\
\hline Collins $2011^{57}$ & $\begin{array}{l}\text { Implicitly, } \\
\text { epidemiologists and } \\
\text { public health clinicians, } \\
\text { for use in UK } \\
\text { population }\end{array}$ & NS & Public health & Useful & $\begin{array}{l}\text { Validated by an } \\
\text { independent team } \\
\text { on an independent } \\
\text { cohort (unlike most } \\
\text { others) }\end{array}$ & None & $\begin{array}{l}\text { NA (not } \\
\text { their risk } \\
\text { score) }\end{array}$ & 0 \\
\hline Gao $2009^{39}$ & $\begin{array}{l}\text { "To be used by } \\
\text { laypersons" to detect } \\
\text { diabetes and raise } \\
\text { awareness, } \\
\text { "particularly in low- } \\
\text { income countries" }\end{array}$ & NS & Lay people & Simple & $\begin{array}{l}\text { Simple, uses } \\
\text { absolute risk, based } \\
\text { on prospective } \\
\text { cohort }\end{array}$ & $\begin{array}{l}\text { Only moderately good } \\
\text { predictive power } \\
\text { (AUROC 71\%) }\end{array}$ & None & 0 \\
\hline $\begin{array}{l}\text { Guerrero-Romero } \\
2010^{58}\end{array}$ & $\begin{array}{l}\text { Intended users not } \\
\text { stated. For use on } \\
\text { unselected Latin } \\
\text { American population }\end{array}$ & $\begin{array}{l}\text { Blood test, } \\
\text { monitoring of } \\
\text { risk, preventive } \\
\text { intervention } \\
\text { targeting } \\
\text { particular risk } \\
\text { factors }\end{array}$ & $\begin{array}{l}\text { Implicitly, } \\
\text { clinical }\end{array}$ & $\begin{array}{l}\text { Quick and easy } \\
\text { to use, few } \\
\text { laboratory } \\
\text { investigations, } \\
\text { cheap }\end{array}$ & $\begin{array}{l}\text { Statistically better } \\
\text { than other scores } \\
\text { for use on a Latin } \\
\text { American } \\
\text { population }\end{array}$ & $\begin{array}{l}\text { Not shown to be cost } \\
\text { effective or to improve } \\
\text { quality of life, needs } \\
\text { external validation }\end{array}$ & None & 0 \\
\hline $\begin{array}{l}\text { Hippisley-Cox } \\
2009^{8}\end{array}$ & $\begin{array}{l}\text { General practice and } \\
\text { public health in areas } \\
\text { of high socioeconomic } \\
\text { and ethnic diversity; } \\
\text { use in "clinical settings" } \\
\text { and by lay public } \\
\text { through a "simple web } \\
\text { calculator" }\end{array}$ & $\begin{array}{l}\text { "To identify and } \\
\text { proactively } \\
\text { intervene" }\end{array}$ & Clinical & $\begin{array}{l}\text { Simple, good } \\
\text { discrimination, } \\
\text { well calibrated, } \\
\text { readily } \\
\text { implementable } \\
\text { in primary care, } \\
\text { cost effective }\end{array}$ & $\begin{array}{l}\text { Includes deprivation } \\
\text { and ethnicity, based } \\
\text { on data from } \\
\text { general practice } \\
\text { record, good } \\
\text { statistical } \\
\text { properties, well } \\
\text { validated, "likely to } \\
\text { reduce... health } \\
\text { inequalities" }\end{array}$ & $\begin{array}{l}\text { Missing values (for } \\
\text { example, smoking, } \\
\text { ethnicity); internal } \\
\text { validation on EMIS } \\
\text { only; better design } \\
\text { would be a } \\
\text { prospective study of } \\
\text { inception cohort }\end{array}$ & $\begin{array}{l}\text { None, but } \\
\text { authors } \\
\text { emphasise } \\
\text { that it } \\
\text { could be } \\
\text { used easily }\end{array}$ & $\begin{array}{l}46 \\
\text { citations, } \\
\text { not } \\
\text { relevant }\end{array}$ \\
\hline Joseph $2010^{40}$ & $\begin{array}{l}\text { Implicitly, } \\
\text { epidemiologists (focus } \\
\text { of paper is } \\
\text { identification and } \\
\text { refinement of risk } \\
\text { factors in a population) }\end{array}$ & $\begin{array}{l}\text { "Lifestyle advice } \\
\text { advocating } \\
\text { physical activity, } \\
\text { healthy low fat } \\
\text { diet, and weight } \\
\text { reduction" }\end{array}$ & $\begin{array}{l}\text { None } \\
\text { specifically } \\
\text { hypothesised }\end{array}$ & NS & $\begin{array}{l}\text { More } \\
\text { comprehensive, } \\
\text { AUROC } 0.85, \\
\text { longer follow-up, } \\
\text { less bias (for } \\
\text { example, in how } \\
\text { incident diabetes } \\
\text { was diagnosed) }\end{array}$ & None mentioned & None & 0 \\
\hline Kahn $2009^{41}$ & $\begin{array}{l}\text { "Insurers or public } \\
\text { health agencies ... to } \\
\text { optimise allocation of } \\
\text { preventive medicine } \\
\text { resources" }\end{array}$ & $\begin{array}{l}\text { "Preventive } \\
\text { interventions" }\end{array}$ & $\begin{array}{l}\text { Clinical, public } \\
\text { health }\end{array}$ & $\begin{array}{l}\text { Low cost, } \\
\text { clinical, simple }\end{array}$ & $\begin{array}{l}\text { Prospectively } \\
\text { validated, may } \\
\text { illuminate cause of } \\
\text { diabetes by } \\
\text { demonstrating new } \\
\text { associations }\end{array}$ & $\begin{array}{l}\text { Limited to age } 45-65 \\
\text { and to white or black } \\
\text { ethnic groups }\end{array}$ & None & $\begin{array}{l}29 \\
\text { citations, } \\
\text { not } \\
\text { relevant }\end{array}$ \\
\hline Kanaya $2005^{59}$ & $\begin{array}{l}\text { To identify "older } \\
\text { persons who should } \\
\text { receive intensive } \\
\text { lifestyle intervention" }\end{array}$ & $\begin{array}{l}\text { "Lifestyle } \\
\text { modification" }\end{array}$ & Clinical & Simple & $\begin{array}{l}\text { Very simple, } \\
\text { validated in several } \\
\text { samples }\end{array}$ & $\begin{array}{l}\text { Needs validating in a } \\
\text { longitudinal study }\end{array}$ & None & 0 \\
\hline
\end{tabular}


Table 3 (continued)

\begin{tabular}{|c|c|c|c|c|c|c|c|c|}
\hline \multirow[b]{2}{*}{ Study } & \multicolumn{2}{|c|}{ Authors' assumptions } & \multirow[b]{2}{*}{$\begin{array}{l}\text { Mechanism } \\
\text { by which } \\
\text { use of risk } \\
\text { score may } \\
\text { improve } \\
\text { outcome }\end{array}$} & \multirow[b]{2}{*}{$\begin{array}{l}\text { Authors' } \\
\text { adjectives to } \\
\text { describe their } \\
\text { risk score }\end{array}$} & \multirow[b]{2}{*}{$\begin{array}{l}\text { Authors' claims } \\
\text { for risk score } \\
\text { over others }\end{array}$} & \multirow[b]{2}{*}{$\begin{array}{l}\text { Authors' stated } \\
\text { concerns about } \\
\text { their risk score }\end{array}$} & \multirow[b]{2}{*}{$\begin{array}{l}\text { Data in } \\
\text { paper on } \\
\text { use of } \\
\text { risk } \\
\text { score in } \\
\text { real } \\
\text { world }\end{array}$} & \multirow{2}{*}{$\begin{array}{c}\text { Citation } \\
\text { tracking } \\
\text { (Google } \\
\text { Scholar) } \\
\text { for } \\
\text { studies } \\
\text { of real } \\
\text { world } \\
\text { use }\end{array}$} \\
\hline & $\begin{array}{l}\text { Who will use risk } \\
\text { score, on which } \\
\text { subgroups or } \\
\text { populations }\end{array}$ & $\begin{array}{l}\text { What will be } \\
\text { offered to } \\
\text { people who } \\
\text { score above } \\
\text { cut-off for } \\
\text { "caseness" }\end{array}$ & & & & & & \\
\hline Kolberg $2009^{42}$ & $\begin{array}{l}\text { For use on "individuals } \\
\text { at highest risk of } \\
\text { developing type } 2 \\
\text { diabetes" }\end{array}$ & $\begin{array}{l}\text { "for whom the } \\
\text { most } \\
\text { comprehensive } \\
\text { prevention } \\
\text { strategies should } \\
\text { be considered" }\end{array}$ & $\begin{array}{l}\text { None } \\
\text { specifically } \\
\text { hypothesised }\end{array}$ & $\begin{array}{l}\text { Objective, } \\
\text { quantitative }\end{array}$ & $\begin{array}{l}\text { Biologically } \\
\text { plausible } \\
\text { ("multi-biomarker"), } \\
\text { convenient, fewer } \\
\text { logistical challenges } \\
\text { to implementation, } \\
\text { better discrimination }\end{array}$ & $\begin{array}{l}\text { Developed in } \\
\text { overweight middle } \\
\text { aged white people, } \\
\text { hence transferability } \\
\text { may be limited }\end{array}$ & None & $\begin{array}{l}29 \\
\text { citations, } \\
\text { not } \\
\text { relevant }\end{array}$ \\
\hline Lindstrom $2003^{68}$ & $\begin{array}{l}\text { Intended users not } \\
\text { stated. Implicitly, those } \\
\text { who (like the authors) } \\
\text { seek to undertake } \\
\text { intervention studies of } \\
\text { diabetes prevention. } \\
\text { For use with "the } \\
\text { general public" }\end{array}$ & $\begin{array}{l}\text { "Direct attention } \\
\text { to modifiable risk } \\
\text { factors." Also, } \\
\text { doing one's own } \\
\text { risk score might } \\
\text { prompt people to } \\
\text { modify their } \\
\text { lifestyle and } \\
\text { prompt them to } \\
\text { get their blood } \\
\text { glucose level } \\
\text { checked }\end{array}$ & $\begin{array}{l}\text { Clinical, lay } \\
\text { people }\end{array}$ & $\begin{array}{l}\text { Simple, } \\
\text { practical, } \\
\text { informative, } \\
\text { fast, } \\
\text { non-invasive, } \\
\text { inexpensive, } \\
\text { reliable, safe }\end{array}$ & $\begin{array}{l}\text { Prospective, large } \\
\text { cohort. "The public } \\
\text { health implications } \\
\text { of the Diabetes Risk } \\
\text { Score are } \\
\text { considerable" }\end{array}$ & $\begin{array}{l}\text { Possible circular } \\
\text { argument-identifying } \\
\text { people based on same } \\
\text { risk factors that would } \\
\text { have prompted their } \\
\text { clinician to measure } \\
\text { random blood glucose } \\
\text { level in the first place }\end{array}$ & $\begin{array}{l}\text { Not in this } \\
\text { paper, but } \\
\text { see citation } \\
\text { track }\end{array}$ & $\begin{array}{l}343 \\
\text { citations, } \\
\text { of which } \\
\text { eight } \\
\text { described } \\
\text { impact } \\
\text { studies }\end{array}$ \\
\hline Liu $2011^{43}$ & $\begin{array}{l}\text { Clinicians. "initial } \\
\text { instrument for } \\
\text { opportunistic screening } \\
\text { in general population", } \\
\text { "could enhance } \\
\text { people's awareness" }\end{array}$ & $\begin{array}{l}\text { Oral glucose } \\
\text { tolerance test, } \\
\text { education, } \\
\text { "opportunity to } \\
\text { engage in } \\
\text { healthy lifestyles } \\
\text { at an early stage" }\end{array}$ & Clinical & $\begin{array}{l}\text { Practical, } \\
\text { effective, } \\
\text { simple, easily } \\
\text { used in clinical } \\
\text { practice }\end{array}$ & $\begin{array}{l}\text { Validated on a } \\
\text { mainland Chinese } \\
\text { population, large } \\
\text { cohort, prospective, } \\
\text { stable prediction } \\
\text { model }\end{array}$ & $\begin{array}{l}\text { Validated in middle } \\
\text { aged to older cohort } \\
\text { so unproved benefit in } \\
\text { younger people. Did } \\
\text { not include family } \\
\text { history of diabetes, as } \\
\text { not on database }\end{array}$ & None & 0 \\
\hline Mainous $2007^{60}$ & $\begin{array}{l}\text { Implicitly, clinicians. } \\
\text { Paper describes } \\
\text { validation of a previous } \\
\text { risk score in a younger } \\
\text { cohort }\end{array}$ & $\begin{array}{l}\text { "Early } \\
\text { recognition and } \\
\text { treatment" }\end{array}$ & Clinical & $\begin{array}{l}\text { NA (they don't } \\
\text { recommend it in } \\
\text { this group) }\end{array}$ & NA & $\begin{array}{l}\text { Poor discriminatory } \\
\text { ability }\end{array}$ & None & $\begin{array}{l}8 \text { citations, } \\
\text { not } \\
\text { relevant }\end{array}$ \\
\hline Mann $2010^{19}$ & $\begin{array}{l}\text { "Clinicians . . . to } \\
\text { stratify their patient } \\
\text { populations" }\end{array}$ & NS & $\begin{array}{l}\text { None } \\
\text { specifically } \\
\text { hypothesised }\end{array}$ & $\begin{array}{l}\text { High } \\
\text { discriminative } \\
\text { ability }\end{array}$ & $\begin{array}{l}\text { Recalibration and } \\
\text { revalidation of } \\
\text { Framingham based } \\
\text { score in large } \\
\text { ethnically diverse } \\
\text { population }\end{array}$ & $\begin{array}{l}\text { Inability to isolate } \\
\text { Mexicans }\end{array}$ & None & $\begin{array}{l}3 \text { citations, } \\
\text { not } \\
\text { relevant }\end{array}$ \\
\hline McNeely $2003^{61}$ & $\begin{array}{l}\text { "Clinical practice." To } \\
\text { predict diabetes risk in } \\
\text { Japanese Americans }\end{array}$ & NS & $\begin{array}{l}\text { None } \\
\text { specifically } \\
\text { hypothesised }\end{array}$ & $\begin{array}{l}\text { None, all data } \\
\text { expressed in } \\
\text { numbers }\end{array}$ & $\begin{array}{l}\text { Better in short term } \\
\text { than fasting blood } \\
\text { glucose test but not } \\
\text { in long term } \\
\text { (younger people). } \\
\text { Not as good as oral } \\
\text { glucose tolerance } \\
\text { test (older people) }\end{array}$ & $\begin{array}{l}\text { "Further refinements } \\
\text { that take into account } \\
\text { the differential effects } \\
\text { of age are needed" }\end{array}$ & None & $\begin{array}{l}29 \\
\text { citations, } \\
\text { not } \\
\text { relevant }\end{array}$ \\
\hline Mehrabi $2010^{44}$ & NS & NS & $\begin{array}{l}\text { Not } \\
\text { specifically } \\
\text { hypothesised }\end{array}$ & Useful, novel & $\begin{array}{l}\text { Higher predictability } \\
\text { rate than use of } \\
\text { single risk factors } \\
\text { alone }\end{array}$ & $\begin{array}{l}\text { New and relatively } \\
\text { untested, some } \\
\text { missing data }\end{array}$ & None & 0 \\
\hline Meigs $2008^{9}$ & $\begin{array}{l}\text { NA-negative study } \\
\text { showing that genetic } \\
\text { factors add nothing to } \\
\text { clinical scores }\end{array}$ & NA & $\begin{array}{l}\text { NA (authors } \\
\text { suggest } \\
\text { further } \\
\text { research on } \\
\text { key } \\
\text { subgroups) }\end{array}$ & $\begin{array}{l}\text { Less useful } \\
\text { than data } \\
\text { collected at a } \\
\text { routine clinical } \\
\text { examination }\end{array}$ & NA & $\begin{array}{l}\text { Did not help to refine } \\
\text { the prediction of } \\
\text { diabetes risk }\end{array}$ & NA & $\begin{array}{l}163 \\
\text { citations, } \\
\text { but not } \\
\text { relevant } \\
\text { as paper } \\
\text { cited for its } \\
\text { negative } \\
\text { findings }\end{array}$ \\
\hline
\end{tabular}


Table 3 (continued)

\begin{tabular}{|c|c|c|c|c|c|c|c|c|}
\hline \multirow[b]{2}{*}{ Study } & \multicolumn{2}{|c|}{ Authors' assumptions } & \multirow[b]{2}{*}{$\begin{array}{l}\text { Mechanism } \\
\text { by which } \\
\text { use of risk } \\
\text { score may } \\
\text { improve } \\
\text { outcome }\end{array}$} & \multirow[b]{2}{*}{$\begin{array}{l}\text { Authors' } \\
\text { adjectives to } \\
\text { describe their } \\
\text { risk score }\end{array}$} & \multirow[b]{2}{*}{$\begin{array}{l}\text { Authors' claims } \\
\text { for risk score } \\
\text { over others }\end{array}$} & \multirow[b]{2}{*}{$\begin{array}{l}\text { Authors' stated } \\
\text { concerns about } \\
\text { their risk score }\end{array}$} & \multirow[b]{2}{*}{$\begin{array}{l}\text { Data in } \\
\text { paper on } \\
\text { use of } \\
\text { risk } \\
\text { score in } \\
\text { real } \\
\text { world }\end{array}$} & \multirow{2}{*}{$\begin{array}{c}\text { Citation } \\
\text { tracking } \\
\text { (Google } \\
\text { Scholar) } \\
\text { for } \\
\text { studies } \\
\text { of real } \\
\text { world } \\
\text { use }\end{array}$} \\
\hline & $\begin{array}{l}\text { Who will use risk } \\
\text { score, on which } \\
\text { subgroups or } \\
\text { populations }\end{array}$ & $\begin{array}{l}\text { What will be } \\
\text { offered to } \\
\text { people who } \\
\text { score above } \\
\text { cut-off for } \\
\text { "caseness" }\end{array}$ & & & & & & \\
\hline Nichols $2008^{62}$ & $\begin{array}{l}\text { Health maintenance } \\
\text { organisations. Based } \\
\text { on analysis of } \\
\text { electronic record data, } \\
\text { to identify members at } \\
\text { high risk of developing } \\
\text { diabetes }\end{array}$ & $\begin{array}{l}\text { "Interventions" } \\
\text { and targeting of } \\
\text { healthcare } \\
\text { resources }\end{array}$ & $\begin{array}{l}\text { Clinical, public } \\
\text { health, } \\
\text { technology }\end{array}$ & $\begin{array}{l}\text { "Extremely } \\
\text { accurate," } \\
\text { simple }\end{array}$ & Better AUROC & $\begin{array}{l}\text { If health maintenance } \\
\text { organisation } \\
\text { population has } \\
\text { different incidence of } \\
\text { type } 2 \text { diabetes from } \\
\text { validation cohort, } \\
\text { score will be } \\
\text { inaccurate }\end{array}$ & None & $\begin{array}{l}1 \text { citation, } \\
\text { not } \\
\text { relevant }\end{array}$ \\
\hline Rahman $2008^{63}$ & $\begin{array}{l}\text { Primary care and } \\
\text { public health clinicians. } \\
\text { Use for "defining } \\
\text { individuals and } \\
\text { populations for testing, } \\
\text { treatment and } \\
\text { prevention" }\end{array}$ & $\begin{array}{l}\text { Not explicitly } \\
\text { stated but } \\
\text { authors suggest } \\
\text { potential } \\
\text { avenues for } \\
\text { impact studies }\end{array}$ & $\begin{array}{l}\text { Clinical, public } \\
\text { health }\end{array}$ & $\begin{array}{l}\text { Simple, } \\
\text { effective }\end{array}$ & $\begin{array}{l}\text { Based on data } \\
\text { routinely available } \\
\text { on general practice } \\
\text { records }\end{array}$ & $\begin{array}{l}\text { Will need to be } \\
\text { validated in other } \\
\text { prospective cohorts }\end{array}$ & None & $\begin{array}{l}29 \\
\text { citations, } \\
\text { not } \\
\text { relevant }\end{array}$ \\
\hline Rathmann $2010^{85}$ & $\begin{array}{l}\text { Intended users not } \\
\text { stated. Use "to identify } \\
\text { high-risk populations } \\
\text { for preventive } \\
\text { strategies" }\end{array}$ & $\begin{array}{l}\text { "Preventive } \\
\text { strategies" }\end{array}$ & Public health & Simple & $\begin{array}{l}\text { Validated in older } \\
\text { population }\end{array}$ & $\begin{array}{l}\text { No external validation } \\
\text { yet }\end{array}$ & None & $\begin{array}{l}1 \text { citation, } \\
\text { not } \\
\text { relevant }\end{array}$ \\
\hline Rosella $2010^{69}$ & $\begin{array}{l}\text { Public health clinicians } \\
\text { and health planners "to } \\
\text { estimate diabetes } \\
\text { incidence, to stratify } \\
\text { the population by risk, } \\
\text { and quantify the effect } \\
\text { of interventions" }\end{array}$ & $\begin{array}{l}\text { "New } \\
\text { intervention } \\
\text { strategies" }\end{array}$ & $\begin{array}{l}\text { Public health, } \\
\text { clinical }\end{array}$ & Simple & $\begin{array}{l}\text { Uses data available } \\
\text { on population } \\
\text { registries }\end{array}$ & $\begin{array}{l}\text { Could be further tested } \\
\text { on other populations. } \\
\text { Family history and } \\
\text { poor diet not collected, } \\
\text { relies on self reports }\end{array}$ & None & $\begin{array}{l}1 \text { citation, } \\
\text { not } \\
\text { relevant }\end{array}$ \\
\hline Schmidt $2005^{46}$ & $\begin{array}{l}\text { Use "in clinical } \\
\text { encounters," "by } \\
\text { managed care } \\
\text { organizations ... to } \\
\text { identify high-risk } \\
\text { individuals," and to } \\
\text { enrol to clinical trials }\end{array}$ & $\begin{array}{l}\text { "Preventive } \\
\text { actions of } \\
\text { appropriate } \\
\text { intensity" }\end{array}$ & $\begin{array}{l}\text { Clinical, public } \\
\text { health, } \\
\text { research }\end{array}$ & $\begin{array}{l}\text { Simple, based } \\
\text { on readily } \\
\text { available } \\
\text { clinical } \\
\text { information and } \\
\text { simple } \\
\text { laboratory tests }\end{array}$ & $\begin{array}{l}\text { Good predictor for } \\
\text { white and } \\
\text { African-American } \\
\text { men and women; } \\
\text { may apply also to } \\
\text { other ethnic groups } \\
\text { in United States }\end{array}$ & $\begin{array}{l}\text { High losses to } \\
\text { follow-up, oral glucose } \\
\text { tolerance test not done } \\
\text { at baseline }\end{array}$ & None & $\begin{array}{l}111 \\
\text { citations, } \\
\text { not } \\
\text { relevant }\end{array}$ \\
\hline Schulze $2007^{70}$ & $\begin{array}{l}\text { Intended users not } \\
\text { stated. "Identifying } \\
\text { individuals at high risk } \\
\text { of developing T2D } \\
\text { [type } 2 \text { diabetes] in the } \\
\text { general population" }\end{array}$ & $\begin{array}{l}\text { Not explicitly } \\
\text { stated }\end{array}$ & The public & $\begin{array}{l}\text { Precise, } \\
\text { non-invasive, } \\
\text { accurate, useful }\end{array}$ & $\begin{array}{l}\text { Good AUROC } \\
(0.84), \text { used } \\
\text { absolute values for } \\
\text { age rather than } \\
\text { broad categories }\end{array}$ & $\begin{array}{l}\text { Self reports may have } \\
\text { been biased }\end{array}$ & None & $\begin{array}{l}114 \\
\text { citations, } \\
\text { not } \\
\text { relevant }\end{array}$ \\
\hline Schulze $2009^{47}$ & NS & NS & $\begin{array}{l}\text { None } \\
\text { specifically } \\
\text { hypothesised }\end{array}$ & $\begin{array}{l}\text { Improved } \\
\text { discrimination }\end{array}$ & $\begin{array}{l}\text { "A comprehensive } \\
\text { basic model," } \\
\text { significantly } \\
\text { improved by routine } \\
\text { blood tests but not } \\
\text { chemical or genetic } \\
\text { biomarkers }\end{array}$ & $\begin{array}{l}\text { Predictive for onset of } \\
\text { diabetes in middle age } \\
\text { but not from birth, } \\
\text { since diabetes was } \\
\text { excluded from } \\
\text { inception cohort }\end{array}$ & None & $\begin{array}{l}17 \\
\text { citations, } \\
\text { not } \\
\text { relevant }\end{array}$ \\
\hline Simmons $2007^{71}$ & $\begin{array}{l}\text { Primary care: "could } \\
\text { inform ... health } \\
\text { behaviour information } \\
\ldots \text {. routinely collected } \\
\text { in GP consultations or } \\
\text { by administrative staff," } \\
\text { identify groups for } \\
\text { targeted prevention }\end{array}$ & $\begin{array}{l}\text { "Could be } \\
\text { incorporated into } \\
\text { new patient } \\
\text { health checks } \\
\text { and may provide } \\
\text { a more feasible } \\
\text { means of } \\
\text { identifying those } \\
\text { at risk than } \\
\text { OGTT [oral } \\
\text { glucose } \\
\text { tolerance test], or } \\
\text { select those }\end{array}$ & $\begin{array}{l}\text { Clinical, } \\
\text { administrative }\end{array}$ & Simple, feasible & $\begin{array}{l}\text { Relies only on } \\
\text { simple questions } \\
\text { about lifestyle, } \\
\text { which would be } \\
\text { asked in a routine } \\
\text { health check. } \\
\text { AUROC }(0.76) \text { is as } \\
\text { good as many } \\
\text { complex risk scores }\end{array}$ & $\begin{array}{l}\text { No better than } \\
\text { standard clinical } \\
\text { dataset routinely } \\
\text { collected in UK } \\
\text { general practice (but } \\
\text { may be feasible in } \\
\text { other health settings) }\end{array}$ & $\begin{array}{l}\text { Feasible to } \\
\text { collect }\end{array}$ & $\begin{array}{l}21 \\
\text { citations, } \\
\text { not } \\
\text { relevant }\end{array}$ \\
\hline
\end{tabular}


Table 3 (continued)

\begin{tabular}{|c|c|c|c|c|c|c|c|c|}
\hline \multirow{3}{*}{ Study } & \multicolumn{2}{|c|}{ Authors' assumptions } & \multirow[b]{2}{*}{$\begin{array}{l}\text { Mechanism } \\
\text { by which } \\
\text { use of risk } \\
\text { score may } \\
\text { improve } \\
\text { outcome }\end{array}$} & \multirow{3}{*}{$\begin{array}{l}\text { Authors' } \\
\text { adjectives to } \\
\text { describe their } \\
\text { risk score }\end{array}$} & \multirow{3}{*}{$\begin{array}{l}\text { Authors' claims } \\
\text { for risk score } \\
\text { over others }\end{array}$} & \multirow{3}{*}{$\begin{array}{l}\text { Authors' stated } \\
\text { concerns about } \\
\text { their risk score }\end{array}$} & \multirow{3}{*}{$\begin{array}{l}\text { Data in } \\
\text { paper on } \\
\text { use of } \\
\text { risk } \\
\text { score in } \\
\text { real } \\
\text { world }\end{array}$} & \multirow{2}{*}{$\begin{array}{c}\text { Citation } \\
\text { tracking } \\
\text { (Google } \\
\text { Scholar) } \\
\text { for } \\
\text { studies } \\
\text { of real } \\
\text { world } \\
\text { use }\end{array}$} \\
\hline & $\begin{array}{l}\text { Who will use risk } \\
\text { score, on which } \\
\text { subgroups or } \\
\text { populations }\end{array}$ & $\begin{array}{l}\text { What will be } \\
\text { offered to } \\
\text { people who } \\
\text { score above } \\
\text { cut-off for } \\
\text { "caseness" }\end{array}$ & & & & & & \\
\hline & & $\begin{array}{l}\text { suitable for } \\
\text { OGTT" }\end{array}$ & & & & & & \\
\hline Stern $1993^{48}$ & $\begin{array}{l}\text { Implicitly, } \\
\text { epidemiological } \\
\text { researchers }\end{array}$ & $\begin{array}{l}\text { "Identifying } \\
\text { high-risk cohorts } \\
\text { for prevention } \\
\text { trials" }\end{array}$ & $\begin{array}{l}\text { Research, } \\
\text { clinical }\end{array}$ & $\begin{array}{l}\text { Predictive, } \\
\text { multivariate }\end{array}$ & $\begin{array}{l}\text { Uses commonly } \\
\text { measured clinical } \\
\text { variables }\end{array}$ & NS & None & $\begin{array}{l}45 \\
\text { citations, } \\
\text { not } \\
\text { relevant }\end{array}$ \\
\hline Stern $2002^{86}$ & $\begin{array}{l}\text { "Could be incorporated } \\
\text { as it stands into clinical } \\
\text { practice and public } \\
\text { health practice with the } \\
\text { aid of a calculator or } \\
\text { personal computer" }\end{array}$ & $\begin{array}{l}\text { Clinical: "patient } \\
\text { counselling." } \\
\text { Public health: "to } \\
\text { identify target } \\
\text { populations for } \\
\text { preventive } \\
\text { interventions" }\end{array}$ & $\begin{array}{l}\text { Clinical, public } \\
\text { health, } \\
\text { technological, } \\
\text { research }\end{array}$ & Simple & $\begin{array}{l}\text { Less expensive and } \\
\text { more convenient } \\
\text { than oral glucose } \\
\text { tolerance testing }\end{array}$ & Possible missing data & None & $\begin{array}{l}245 \\
\text { citations, } \\
\text { not } \\
\text { relevant }\end{array}$ \\
\hline Sun $2009^{72}$ & $\begin{array}{l}\text { Use in clinical } \\
\text { encounter, by } \\
\text { managed care } \\
\text { organisations to } \\
\text { identify high risk } \\
\text { people, and to enrol to } \\
\text { clinical trials }\end{array}$ & Further research & $\begin{array}{l}\text { Clinical, } \\
\text { technological, } \\
\text { research }\end{array}$ & $\begin{array}{l}\text { Simple, } \\
\text { effective, } \\
\text { accurate }\end{array}$ & $\begin{array}{l}\text { Simple, uses readily } \\
\text { available clinical } \\
\text { information }\end{array}$ & $\begin{array}{l}\text { Losses to follow-up, } \\
\text { oral glucose tolerance } \\
\text { test not done at } \\
\text { baseline so some } \\
\text { cases detected, } \\
\text { especially early on, } \\
\text { may be prevalent ones }\end{array}$ & None & $\begin{array}{l}3 \text { citations, } \\
\text { not } \\
\text { relevant }\end{array}$ \\
\hline Talmud $2010^{10}$ & $\begin{array}{l}\text { Intended users not } \\
\text { stated (but study used } \\
\text { an existing risk score } \\
\text { as a "control" for } \\
\text { testing a genetic } \\
\text { profile) }\end{array}$ & NS & $\begin{array}{l}\text { Not } \\
\text { specifically } \\
\text { hypothesised }\end{array}$ & $\begin{array}{l}\text { NA } \\
\text { (revalidation) }\end{array}$ & $\begin{array}{l}\text { Simple clinical risk } \\
\text { scores performed } \\
\text { much better than } \\
\text { assessment of } \\
\text { genetic risk from } 40 \\
\text { polymorphisms }\end{array}$ & NA & None & $\begin{array}{l}21 \\
\text { citations, } \\
\text { not } \\
\text { relevant }\end{array}$ \\
\hline Urdea $2009^{64}$ & $\begin{array}{l}\text { "Current clinical } \\
\text { practice"; for } \\
\text { "identifying individuals } \\
\text { at highest risk of } \\
\text { developing T2DM [type } \\
2 \text { diabetes mellitus]" }\end{array}$ & $\begin{array}{l}\text { "so that clinicians } \\
\text { can implement } \\
\text { an effective } \\
\text { diabetes } \\
\text { prevention } \\
\text { program" }\end{array}$ & Clinical & $\begin{array}{l}\text { Simple, } \\
\text { accurate, } \\
\text { convenient }\end{array}$ & $\begin{array}{l}\text { "Better than any } \\
\text { other clinical } \\
\text { measure", not } \\
\text { over-fit, based on } \\
\text { multiple biomarkers } \\
\text { hence highly } \\
\text { plausible }\end{array}$ & NS & None & $\begin{array}{l}6 \text { citations, } \\
\text { not } \\
\text { relevant }\end{array}$ \\
\hline $\begin{array}{l}\text { Von Eckardstein } \\
2000^{50}\end{array}$ & $\begin{array}{l}\text { NA (negative study, no } \\
\text { better than fasting } \\
\text { blood glucose test } \\
\text { alone in this cohort) }\end{array}$ & $\begin{array}{l}\text { NA (negative } \\
\text { study) }\end{array}$ & NA & $\begin{array}{l}\text { NA (negative } \\
\text { study) }\end{array}$ & NA & Negative study & NA & $\begin{array}{l}56 \\
\text { citations, } \\
\text { not } \\
\text { relevant }\end{array}$ \\
\hline $\begin{array}{l}\text { Wannamethee } \\
2011^{27}\end{array}$ & $\begin{array}{l}\text { Intended users not } \\
\text { stated }\end{array}$ & $\begin{array}{l}\text { Not stated, unit } \\
\text { of analysis is the } \\
\text { population }\end{array}$ & $\begin{array}{l}\text { Not } \\
\text { specifically } \\
\text { hypothesised }\end{array}$ & $\begin{array}{l}\text { NA (less } \\
\text { effective than } \\
\text { Framingham } \\
\text { risk score) }\end{array}$ & $\begin{array}{l}\text { "Useful predictor" } \\
\text { (but not as good as } \\
\text { Framingham score) }\end{array}$ & NS & None & $\begin{array}{l}273 \\
\text { citations, } \\
\text { not } \\
\text { relevant }\end{array}$ \\
\hline $\begin{array}{l}\text { Wannamethee } \\
2005^{65}\end{array}$ & $\begin{array}{l}\text { Intended users not } \\
\text { stated }\end{array}$ & Blood tests & $\begin{array}{l}\text { Not } \\
\text { specifically } \\
\text { hypothesised }\end{array}$ & Simple, routine & Stepwise & $\begin{array}{l}\text { Diabetes diagnosed by } \\
\text { self reports }\end{array}$ & None & 0 \\
\hline Wilson $2007^{51}$ & Implicitly, clinicians & $\begin{array}{l}\text { Implicitly, lifestyle } \\
\text { advice and } \\
\text { metformin }\end{array}$ & Clinical & $\begin{array}{l}\text { Simple, } \\
\text { effective, easy }\end{array}$ & $\begin{array}{l}\text { Very good AUROC } \\
(85 \%)\end{array}$ & NS & None & $\begin{array}{l}143 \\
\text { citations, } \\
\text { not } \\
\text { relevant }\end{array}$ \\
\hline
\end{tabular}

$\mathrm{NS}=$ not stated; $\mathrm{NA}=$ not applicable; $\mathrm{BMI}=$ body mass index; $\mathrm{AUROC}=$ area under receiver operating characteristic curve. 


\begin{tabular}{|c|c|c|c|c|c|c|}
\hline \multirow{2}{*}{$\begin{array}{l}\text { Score/study name, } \\
\text { country, reference }\end{array}$} & \multirow[b]{2}{*}{ Risk factors included in score } & \multirow[b]{2}{*}{ AUROC } & \multirow[b]{2}{*}{ Calibration } & \multicolumn{3}{|c|}{ External validation } \\
\hline & & & & Year, country & AUROC & Calibration \\
\hline $\begin{array}{l}\text { ARIC (Atherosclerosis } \\
\text { Risk in Communities), } \\
\text { Germany, Schmidt } \\
2005^{46}\end{array}$ & $\begin{array}{l}\text { Age, ethnicity, waist circumference, height, } \\
\text { systolic blood pressure, family history of } \\
\text { diabetes, fasting plasma glucose levels, } \\
\text { triglyceride levels, high density lipoprotein } \\
\text { cholesterol levels }\end{array}$ & 0.80 & NS & $2010,,^{19}$ USA & 0.84 & $\begin{array}{l}\text { Hosmer-Lemeshow } \\
P<0.001 \text {, after } \\
\text { recalibration } P>0.10\end{array}$ \\
\hline $\begin{array}{l}\text { Ausdrisk, Australia, } \\
\text { Chen } 2010^{37}\end{array}$ & $\begin{array}{l}\text { Age, sex, ethnicity, parental history of } \\
\text { diabetes, history of high blood glucose, } \\
\text { use of antihypertensive drugs, smoking, } \\
\text { physical inactivity, waist circumference }\end{array}$ & 0.78 & $\begin{array}{l}\text { Hosmer-Lemeshow } \\
\mathrm{P}=0.85\end{array}$ & \multicolumn{3}{|c|}{$\begin{array}{l}\text { Not externally validated but has been studied as part of an } \\
\text { intervention to improve outcomes }{ }^{87}\end{array}$} \\
\hline $\begin{array}{l}\text { Cambridge risk score, } \\
\text { UK, Rahman } 2008^{63}\end{array}$ & $\begin{array}{l}\text { Age, sex, use of current corticosteroids, } \\
\text { use of antihypertensive drugs, family } \\
\text { history of diabetes, body mass index, } \\
\text { smoking }\end{array}$ & $\begin{array}{l}0.74 \text { with } \\
\text { threshold of } \\
0.38\end{array}$ & NS & $2010,{ }^{10} \mathrm{UK}^{*}$ & 0.72 & $\begin{array}{l}\text { Hosmer-Lemeshow } \\
\mathrm{P}=0.77\end{array}$ \\
\hline $\begin{array}{l}\text { FINDRISC, Finland, } \\
\text { Lindstrom } 2003^{68}\end{array}$ & $\begin{array}{l}\text { Age, body mass index, waist } \\
\text { circumference, use of antihypertensive } \\
\text { drugs, history of high blood glucose, } \\
\text { physical inactivity, daily consumption of } \\
\text { vegetables, fruits, and berries }\end{array}$ & 0.85 & NS & $\begin{array}{l}2010,{ }^{53} \text { Holland, } \\
\text { Denmark, } \\
\text { Sweden, UK, } \\
\text { Australia* }\end{array}$ & 0.76 & $\begin{array}{l}\text { Hosmer-Lemeshow } \\
\mathrm{P}=0.27\end{array}$ \\
\hline $\begin{array}{l}\text { Framingham Offspring } \\
\text { Study, USA, Wilson } \\
2007^{51}\end{array}$ & $\begin{array}{l}\text { Fasting plasma glucose levels, body mass } \\
\text { index, high density lipoprotein cholesterol } \\
\text { levels, parental history of diabetes, } \\
\text { triglyceride levels, blood pressure }\end{array}$ & 0.85 & NS & $2010,{ }^{19}$ USA & 0.78 & $\begin{array}{l}\text { Hosmer-Lemeshow } \\
\mathrm{P}<0.001 \text {, after } \\
\text { recalibration } \mathrm{P}>0.10\end{array}$ \\
\hline $\begin{array}{l}\text { San Antonio risk score, } \\
\text { clinical model, USA, } \\
\text { Stern } 2002^{49}\end{array}$ & $\begin{array}{l}\text { Age, sex, ethnicity, fasting plasma glucose } \\
\text { levels, systolic blood pressure, high } \\
\text { density lipoprotein cholesterol levels, body } \\
\text { mass index, family history of diabetes in } \\
\text { first degree relative }\end{array}$ & 0.84 & $\begin{array}{l}\text { Hosmer-Lemeshow } \\
P>0.2\end{array}$ & $\begin{array}{l}2010,{ }^{19} \mathrm{USA} \\
2010,{ }^{55} \mathrm{Iran}^{*} \\
2010,{ }^{10} \mathrm{UK}^{\star} \\
2010,{ }^{66} \mathrm{Iran}^{\star}\end{array}$ & $\begin{array}{l}0.83 ; 0.83 \\
0.78 ; 0.78\end{array}$ & $\begin{array}{l}\text { Hosmer-Lemeshow } \\
P<0.001 \text {, after } \\
\text { recalibration } P>0.10 ; \\
\text { Hosmer-Lemeshow } \\
P \leq 0.001 \text {, after } \\
\text { recalibration } P=0.131 \text {; } \\
\text { Hosmer-Lemeshow } \\
P=0.42 \text {; } \\
\text { Hosmer-Lemeshow } \\
P=0.264\end{array}$ \\
\hline $\begin{array}{l}\text { QDScore, UK, } \\
\text { Hippisley-Cox } 2009^{8}\end{array}$ & $\begin{array}{l}\text { Age, sex, ethnicity, body mass index, } \\
\text { smoking, family history of diabetes, } \\
\text { Townsend deprivation score, treated } \\
\text { hypertension, cardiovascular disease, } \\
\text { current use of corticosteroids }\end{array}$ & $\begin{array}{l}0.83 \text { men, } \\
0.85 \\
\text { women }\end{array}$ & $\begin{array}{l}\text { Brier score: } 0.078 \\
\text { men, } 0.058 \text { women }\end{array}$ & $2011,{ }^{57}$ UK & $\begin{array}{l}0.80 \text { men, } \\
0.81 \text { women }\end{array}$ & $\begin{array}{l}\text { Brier score: } 0.053 \text { men, } \\
0.041 \text { women }\end{array}$ \\
\hline
\end{tabular}

AUROC=area under receiver operating characteristic curve; NS=not stated.

*Validation used more, less, or substituted risk factors from original risk score or did not state the exact factors it used. See table 2 for further details. 


\begin{tabular}{|c|c|c|c|c|c|c|}
\hline \multicolumn{7}{|c|}{ Table 5 Results of impact citation search (studies using diabetes risk models or scores as part of an intervention to improve outcomes) } \\
\hline $\begin{array}{l}\text { Study } \\
\text { (acronym) }\end{array}$ & Score used & Research question & $\begin{array}{l}\text { Setting and } \\
\text { sample }\end{array}$ & $\begin{array}{l}\text { Study design, } \\
\text { intervention }\end{array}$ & $\begin{array}{l}\text { Main findings or expected } \\
\text { reporting date }\end{array}$ & Comment \\
\hline 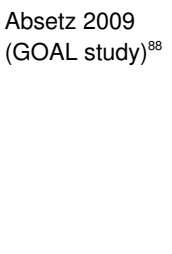 & FINDRISC ${ }^{68}$ & $\begin{array}{l}\text { Can diabetes risk be } \\
\text { reduced by lifestyle } \\
\text { counselling? }\end{array}$ & $\begin{array}{l}\text { Australia, } 352 \\
\text { high risk adults }\end{array}$ & $\begin{array}{l}\text { Real world feasibility } \\
\text { study: eight lifestyle } \\
\text { counselling sessions }\end{array}$ & $\begin{array}{l}271 / 352 \text { completed study. } \\
\text { Showed statistically } \\
\text { significant reduction in } \\
\text { weight, body mass index, } \\
\text { and total cholesterol level, } \\
\text { maintained at } 36 \text { months }\end{array}$ & $\begin{array}{l}\text { Changes only reported on } \\
\text { "completers"; those lost to } \\
\text { follow-up were not included in } \\
\text { analysis. Absolute changes were } \\
\text { small and probably not clinically } \\
\text { significant-for example, mean } 1 \\
\text { kg weight loss. Change in } \\
\text { FINDRISC score was not reported }\end{array}$ \\
\hline
\end{tabular}

\begin{tabular}{|c|c|c|c|c|}
\hline $\begin{array}{l}\text { Jallinoja } 2008 \\
\text { (GOAL study) }^{89}\end{array}$ & FINDRISC $^{68}$ & $\begin{array}{l}\text { What is the } \\
\text { experience of lifestyle } \\
\text { change in people } \\
\text { recruited into diabetes } \\
\text { prevention studies? }\end{array}$ & $\begin{array}{l}\text { Australia, } 30 \\
\text { weight losers } \\
\text { and } 30 \text { weight } \\
\text { gainers from } \\
\text { GOAL study }\end{array}$ & $\begin{array}{l}\text { Focus groups with } \\
\text { weight losers and weight } \\
\text { gainers studied } \\
\text { separately }\end{array}$ \\
\hline 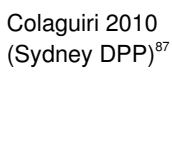 & AUSD-RISK ${ }^{37}$ & $\begin{array}{l}\text { Can diabetes risk be } \\
\text { reduced by a } \\
\text { programme of } \\
\text { intensive behaviour } \\
\text { change? }\end{array}$ & $\begin{array}{l}\text { Australia, } 1550 \\
\text { high risk adults } \\
\text { (100 indigenous } \\
\text { people) }\end{array}$ & $\begin{array}{l}\text { Real world feasibility } \\
\text { study: individual } \\
\text { assessment followed by } \\
\text { group sessions }\end{array}$ \\
\hline
\end{tabular}

Many found dietary change Some but not all people who did not achieve weight achieve it, but most will struggle loss felt despondent

Results expected 2013. Participants will be recruited in
Main outcomes will be primary care, but intervention will change in weight, physical be delivered as a public activity, diet, fasting glucose health/community based levels, blood pressure, lipid programme levels, quality of life, and health service utilisation

\begin{tabular}{lll}
\hline $\begin{array}{l}\text { Kulzer 2009 } \\
\text { (PREDIAS) }^{90}\end{array}$ & FINDRISC $^{68}$ & $\begin{array}{l}\text { Can diabetes risk be Germany, } 182 \\
\text { reduced by lessons in high risk adults } \\
\text { lifestyle modification? }\end{array}$
\end{tabular}

Randomised trial. Intervention group received 12 group lessons in lifestyle modification, controls had leaflet

Laatikainen

2007 FINDRISC $^{68}$ Can risk factor Australia, 237

Real world fect

$\left(\right.$ GGTDPP) ${ }^{91}$ reduction be achieved high risk adults in a high risk non-trial population?
Real world feasibility study: six sessions of nurse led group education

\section{Statistically significant} changes in weight, physical was clinically significant $(3.8 \mathrm{~kg})$; activity, diet, and fasting fasting glucose in the control group glucose levels at 12 months increased, whereas that in the compared with controls intervention group decreased. However, follow-up was short

Statistically significant improvements in weight, fasting and two hour glucose levels, and lipid levels at 12 months

\begin{tabular}{|c|c|c|c|c|c|c|}
\hline $\begin{array}{l}\text { Saaristo } 2007 \\
(\text { FIN-D2D })^{80} \text { and } \\
\text { Lindstrom } 2010 \\
(\text { FIN-D2D) })^{74}\end{array}$ & FINDRISC $^{68}$ & $\begin{array}{l}\text { Can a population } \\
\text { approach detect high } \\
\text { risk people, modify } \\
\text { their risk through } \\
\text { educational } \\
\text { intervention, and } \\
\text { thereby reduce the } \\
\text { incidence of new } \\
\text { diabetes? }\end{array}$ & $\begin{array}{l}\text { Finland, high } \\
\text { risk adults (part } \\
\text { of a national } \\
\text { diabetes } \\
\text { prevention } \\
\text { programme that } \\
\text { also included } \\
\text { population } \\
\text { component) }\end{array}$ & $\begin{array}{l}\text { High scorers on } \\
\text { FINDRISC had oral } \\
\text { glucose tolerance and } \\
\text { lipid levels tested; those } \\
\text { without diabetes were } \\
\text { offered nurse led } \\
\text { community based } \\
\text { individual or group } \\
\text { sessions, or both, based } \\
\text { on stages of change and } \\
\text { tailored to individual } \\
\text { profile }\end{array}$ & $\begin{array}{l}\text { Preliminary results only. } \\
\text { Numbers and detailed } \\
\text { findings not given. } \\
\text { "Desirable changes" at } 12 \\
\text { months in risk factors and } \\
\text { glucose tolerance in high } \\
\text { risk cohort. Incident } \\
\text { diabetes reduced (as } \\
\text { measured by drug } \\
\text { reimbursement registration } \\
\text { data). Full results expected } \\
2012-13\end{array}$ & $\begin{array}{l}\text { Authors report that "certain } \\
\text { problems and challenges were } \\
\text { encountered, especially in relation } \\
\text { to the limited resources allotted to } \\
\text { preventive health-care." }{ }^{74} \mathrm{~A} \text { smaller } \\
\text { ongoing prevention programme } \\
\text { using FINDRISC along with } \\
\text { occupational health screening on } \\
\text { an occupational cohort in an airline } \\
\text { company (FINNAIR diabetes } \\
\text { prevention study) is also briefly } \\
\text { outlined in Lindstrom paper }{ }^{74}\end{array}$ \\
\hline 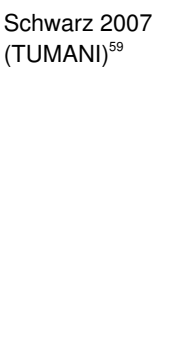 & FINDRISC $^{68}$ & $\begin{array}{l}\text { Can an intensive, } \\
\text { multifaceted public } \\
\text { health intervention } \\
\text { prevent incident } \\
\text { diabetes in high risk } \\
\text { people? }\end{array}$ & $\begin{array}{l}\text { Germany, high } \\
\text { risk adults (part } \\
\text { of a national } \\
\text { prevention } \\
\text { programme) }\end{array}$ & $\begin{array}{l}\text { High scorers on } \\
\text { FINDRISC had oral } \\
\text { glucose tolerance test } \\
\text { before being assigned a } \\
\text { "prevention manager" for } \\
\text { education, support, and } \\
\text { telephone counselling }\end{array}$ & Results expected 2012-13 & $\begin{array}{l}\text { Authors recognise that prevention } \\
\text { on a large scale sits oddly within } \\
\text { the existing treatment oriented } \\
\text { health system. Key features of } \\
\text { TUMANI are prevention managers } \\
\text { working within the existing } \\
\text { infrastructure, a structured quality } \\
\text { control programme, and a } \\
\text { population component-for } \\
\text { example, website and links to } \\
\text { mass media }\end{array}$ \\
\hline $\begin{array}{l}\text { Vermunt } 2010 \\
\text { (APHRODITE) }^{92}\end{array}$ & FINDRISC $^{68}$ & $\begin{array}{l}\text { Can a mailed } \\
\text { questionnaire from } \\
\text { general practice } \\
\text { identify high risk } \\
\text { people to participate } \\
\text { in a preventive } \\
\text { intervention? }\end{array}$ & $\begin{array}{l}\text { Netherlands, } 48 \\
\text { general } \\
\text { practices }\end{array}$ & $\begin{array}{l}\text { General practitioners } \\
\text { mailed questionnaires to } \\
\text { their adult patients. High } \\
\text { scorers were offered } \\
\text { oral glucose tolerance } \\
\text { test }\end{array}$ & $\begin{array}{l}16032 \text { people were mailed; } \\
\text { response rate to } \\
\text { questionnaire } 54.6 \% \text {, of } \\
\text { which } 17.5 \% \text { were classified } \\
\text { as high risk. Of these, } \\
73.1 \% \text { booked a } \\
\text { consultation with their } \\
\text { general practitioner. Full } \\
\text { results expected } 2014\end{array}$ & $\begin{array}{l}\text { Findings to date suggest that half } \\
\text { of high risk patients were willing to } \\
\text { fill out the FINDRISC questionnaire } \\
\text { and follow-up with their general } \\
\text { practitioner. Response rates to } \\
\text { questionnaire varied significantly } \\
\text { among practices }\end{array}$ \\
\hline
\end{tabular}




\section{Figures}

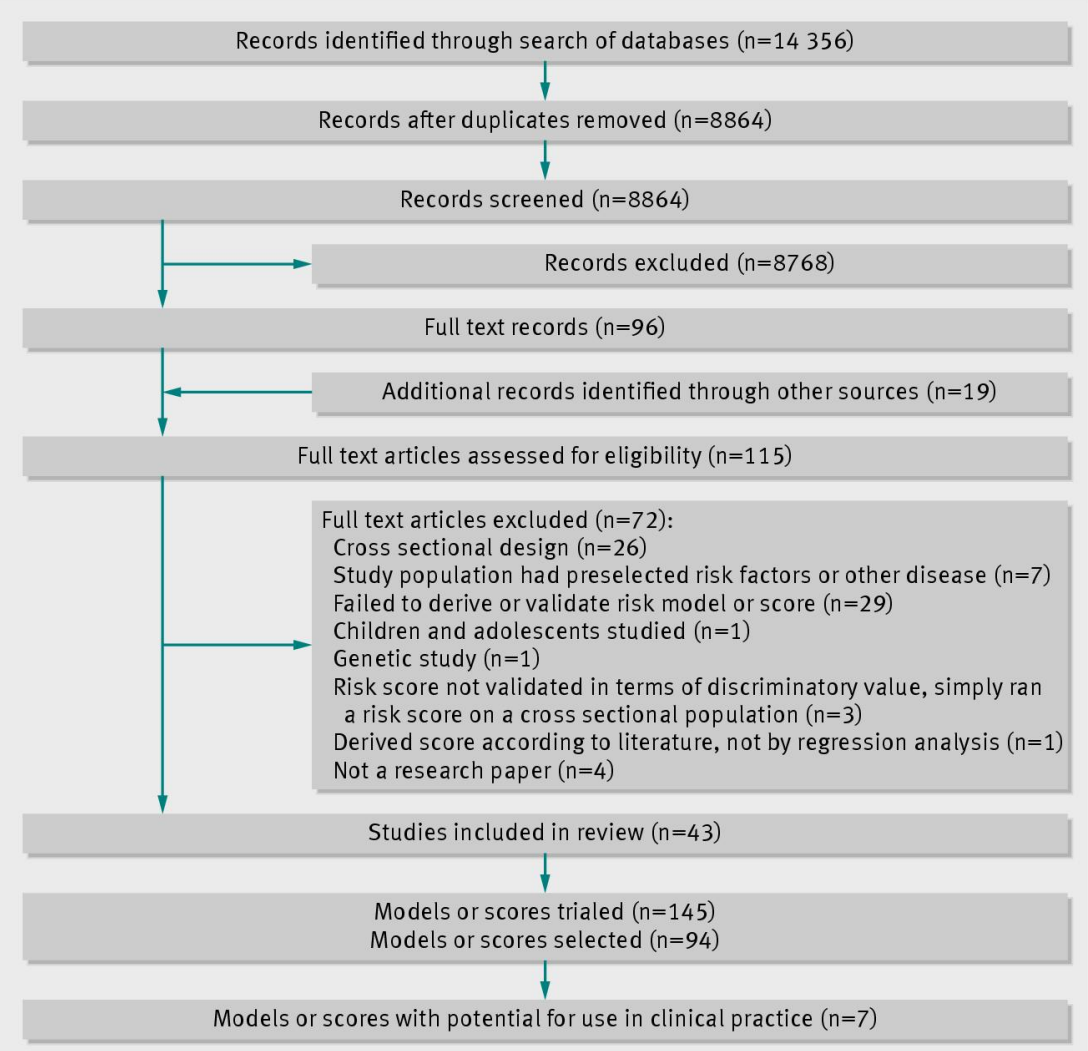

Fig 1 Flow of studies through review

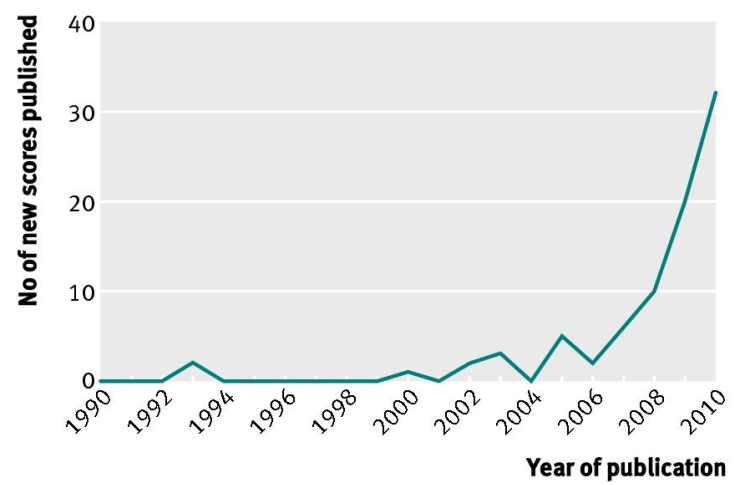

Fig 2 Publication of diabetes risk models and scores 1990-2010. Eleven new risk models and scores had been published in the first five months of 2011 